\author{
Universidade de Brasília \\ Departamento de Teoria Literária e Literaturas \\ Programa de Pós-Graduação em Literatura
}

Luísa Leite S. de Freitas

\title{
O FLUIR-RICORSO E OS TEMPOS DE FINNEGANS WAKE
}




\author{
Universidade de Brasília \\ Departamento de Teoria Literária e Literaturas \\ Programa de Pós-Graduação em Literatura
}

\author{
Luísa Leite S. de Freitas
}

\title{
O FLUIR-RICORSO E OS TEMPOS DE FINNEGANS WAKE
}

Dissertação apresentada ao curso de Mestrado em Literatura do Departamento de Teoria Literária e Literaturas da Universidade de Brasília, como parte dos requisitos para obtenção do grau de Mestre, elaborada sob orientação do Professor Dr. Piero Luis Zanetti Eyben.

Brasília - DF

2014 


\section{LUíSA LEITE S. DE FREITAS}

\section{O FLUIR-RICORSO E OS TEMPOS DE FINNEGANS WAKE}

Dissertação apresentada ao curso de Mestrado em Literatura do Departamento de Teoria Literária e Literaturas da Universidade de Brasília, aprovada pela banca examinadora.

Brasília, 16 de dezembro de 2014.

\begin{tabular}{c} 
Dr. Piero Luis Zanetti Eyben \\
Universidade de Brasília — Presidente \\
\hline Dr. Caetano Waldrigues Galindo \\
Universidade Federal do Paraná — Membro Externo \\
\hline Dr. Henryk Siewierski \\
Universidade de Brasília - Membro Interno
\end{tabular}

Dra. Cristina Maria Teixeira Stevens

Universidade de Brasília - Membro Interno - Suplente 
aos meus pais 
São 23 anos de agradecimentos diversos. Vamos lá, paciência.

aos meus pais, que há tanto tempo reforçam os valores que sempre me passaram: minha mãe, linda fonte de amor na sua forma mais pura, mulher que mais admiro no mundo e que sintetiza comprometimento, devoção e moral;

meu pai, minha referência máxima cuja paixão e ética tanto admiro e que sempre me influenciaram, além de ser certamente a mais incrível combinação de compositor, escritor e professor que possa existir;

aos meus queridos avós que descansam em paz em algum lugar e

à minha avó wanda, por quem meu amor é absolutamente infinito;

aos meus dois irmãos e às minhas duas irmãs:

camila, irmã mais velha para quem ainda olho com olhar de criança, tamanha é minha admiração por seu talento, sensibilidade e força;

felipe, maninho mais velho em quem por toda a infância me espelhei - e de quem tanto peguei discos e bonecos do power rangers sem permissão;

miguel, que desde que veio ao mundo se mostra cada vez mais como um grande ser humano; julinha, que tornou nossas vidas mais doces e mais risonhas - e, do jeito que o tempo passa, em breve vai estar lendo ela mesma esta frase.

estendo isto aqui ainda aos meus irmãos de consideração (nada de meios irmãos - tenho somente irmãos inteiros), tia sandra e e meus tantos familiares todos, que provam que amor não se divide, mas se multiplica;

àquele que está sempre lá para mim há sete anos e a quem tanto amo, marcos oliveira;

à isabella carrazza, que desempenha o papel primordial de amiga inseparável desde 2001;

ao igor versiani e ao henrique barbosa, os melhores amigos que os últimos anos me deram e que espero ter sempre por perto, não importa em que lugar do mundo estejam, porque temos não um cantinho, mas verdadeiros latifúndios no coração uns dos outros;

à joana melo, que me ofereceu sua amizade tão especial por toda a graduação\&além, e a quem só posso agradecer por isso e fazer jus a essa troca;

à stephanie winkler, pela sua amizade tão profunda e inigualável;

ao pedro couto, meu grande amigo com quem tenho a sintonia sagitta em tantos níveis;

ao lucas lyra, que às vezes me entende como poucos e a quem quero tão bem;

à raquel campos, amiga-irmã de companheirismo tão vasto, fez desse tempo de mestrado algo muito melhor;

à ludimila menezes, amiga-em-forma-bruta, enche meus dias de beleza com sua enorme sinceridade de alma que me enche de força e alegria; 
ao rafael machado, que se desdobra em mil e eu tanto admiro, por seu apoio incomensurável e pelo convívio;

à sarah jeanne, cujo companheirismo fez toda a diferença e por quem nutro o maior carinho possível, e também ao victor fialho e à sayuri hirako, queridos, que coloriram esse tempo junto conosco;

às feministas-realmente-amigas-queer-pós-modernxs-pan-normativxs, grupo no qual a mariana ferreira me incluiu e cujo nome já define a genialidade;

amanda quadrado, ana paula jacob, líria nogueira, lorena figueiredo, luciana torres, marcella fernandes, thauana tavares: cada uma de vocês tem um espaço de carinho e amor dentro de mim;

ao joyce e à sua filha que o inspirou, lucia;

mas também ao proust, ao dante, à emily dickinson, ao truffaut e à sofia coppola, à fiona apple, à brody dalle e ao rufus wainwright, ao georges bizet e ao giacomo puccini;

às cidades: brasília, com sua vastidão, e belo horizonte, com seu acolhimento;

à música, a arte que, tanto quanto literatura e filosofia, me mantém viva e mantém em mim o interesse por me manter viva;

ao prof. piero eyben, mais do que orientador desta dissertação, modificou para sempre minha relação com a graduação em Letras e com a academia e cujas aulas nunca mais quis parar de frequentar desde 2011: pelos tantos ensinamentos, pelo acolhimento e pela capacidade de redefinir esse meu percurso, obrigada, minha gratidão não tem limites e este trabalho não existiria sem tudo isso;

à Capes, pelo apoio financeiro;

à Universidade de Brasília, pela importância que ganha mais espaço em mim desde 2009;

a todos que passaram pela minha vida deixando alguma marca e que não nomeei aqui, certamente me tornei outra depois de vocês. digo seus nomes em silêncio.

obrigada. 
First we feel. Then we fall.

(FW, 627.11)

Now follow we out by Starloe!

(FW, 382.30) 


\section{Resumo}

FREITAS, Luísa. O fluir-ricorso e os tempos de Finnegans wake. Dissertação de Mestrado. Orientador Piero Luis Zanetti Eyben. Brasília: Universidade de Brasília, 2014, 151 p.

Esta dissertação percorre investigações acerca do tempo, tanto como instância narrativa, tanto como conceito de teorias filosóficas, a partir da obra última do escritor irlandês James Joyce (1882-1941), Finnegans wake (1939). O aporte teórico perpassa a fenomenologia e, em especial, a filosofia de Jacques Derrida (1930-2004). O ricorso, termo que provém da obra do filósofo Giambattista Vico (1668-1744), é aqui relido como fluir-ricorso, em uma ampliação das investigações sobre o tempo no Finnegans wake para além da Scienza nuova (1725), seu paradigma central. O tempo como também formador de memória, diacronia coletiva, compartilhada, traz à tona o questionamento da inserção ou exclusão de certos textos no cânone da história da literatura e como esse sistema pôde lidar com as peculiaridades do texto de Finnegans wake, desde a recepção de seus contemporâneos modernistas. Sobre o tempo do próprio texto, suas relações com música e outras artes, outro importante filósofo para o trabalho é Emmanuel Levinas (1906-1995). Lidando com sincronia, diacronia e anacronismo, traçamos as possibilidades de entender o tempo do texto do Wake, com o apoio desses termos como abordados pelo filósofo. Ainda nesse âmbito, é também discutido, em parte deste trabalho, o tempo da tradução - ou seus tempos - e apontadas as traduções brasileiras para o texto de James Joyce. A leitura das traduções é feita sempre no esteio das discussões do tempo, bem como o questionamento sobre o cânone literário e a história da literatura, que partem igualmente dessas noções, passando também por Agostinho, Martin Heidegger e Paul Ricoeur.

Palavras-chave: James Joyce; Finnegans wake; Tempo; Jacques Derrida; Fenomenologia. 


\begin{abstract}
FREITAS, Luísa. The flowing-ricorso and the times of Finnegans wake. Master's dissertation. Supervised by Piero Luis Zanetti Eyben. Brasília: University of Brasília, 2014, 151 p.

This dissertation investigates different notions of time, considered as a narrative concept as well as a philosophical concept and center of philosophical theories, from the last work by the Irish author James Joyce (1882-1941), Finnegans wake (1939). The theoretical framework goes through phenomenology and especially the philosophy of Jacques Derrida (1930-2004). The ricorso, term we take from the works of the Italian philosopher Giambattista Vico (1668-1744), is reinterpreted here as a flowing-ricorso, invoking the movement of a river, broadening the investigations on time concerning Finnegans wake beyond what we can see with Scienza nuova (1725), its central paradigm. The notion of time also as a memory, a shared collective diachronic vision, elicits the questioning of the insertion or exclusion of some texts among the canonical ones in the history of literature and how this system can deal with the peculiarities of Finnegans wake, ever since its first reception, by the contemporary modernists. About the time within the text itself, its relations with music and other forms of art, another important philosopher here is Emmanuel Levinas (1906-1995). Dealing with synchronic, diachronic and anachronism, we find the possibilities of understanding the time of the text in the case of Finnegans Wake, with the support of Levinas' approach of these terms. Still concerning those themes, the time of a translation is also brought to this analysis - or its sundry times - and the different Brazilian translations for James Joyce's text are indicated. The approach of this analysis of translations is based on the investigation of the concept of time and the questions concerning the literary canon and the history of literature, all of these being connected notions, also reading the works of Agostinho, Martin Heidegger and Paul Ricoeur.
\end{abstract}

Keywords: James Joyce; Finnegans wake; Time; Jacques Derrida; Phenomenology. 


\section{Sumário}

INTRODUÇÃO - Wake e environs..............................................................11

CAPÍTULO I - Wake em pauta.................................................................30

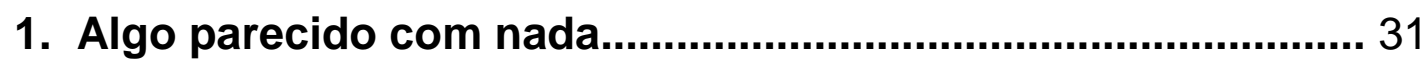

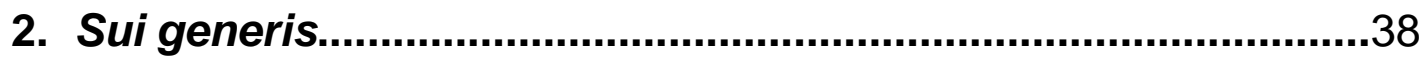

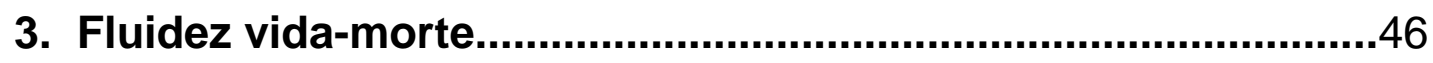

4. Paralelos: psicanálise, teoria da relatividade, música...............51

CAPÍTULO II - Finnegans wake e o tempo da tradução.........................64

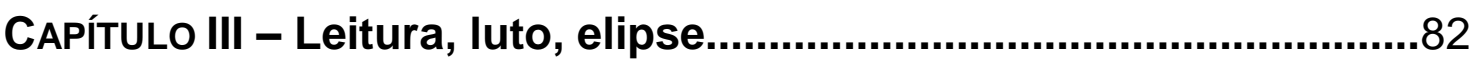

CAPÍTULO IV - Fluir e retorno................................................................108

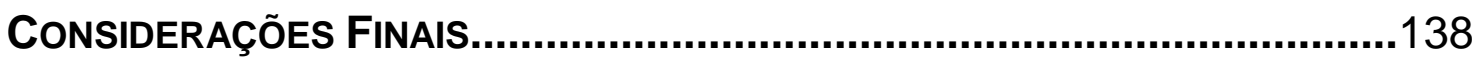

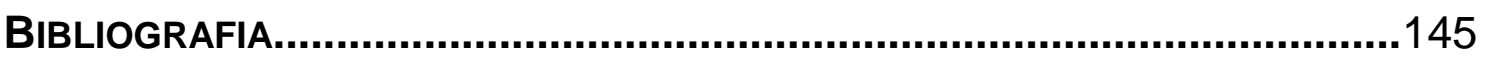




\section{INTRODUÇÃO: WAKE E ENVIRONS}

Hightime is ups be it down into outs according!

Premente é o tempo que seja feito do teu jeito. ${ }^{1}$

(FW, 239.16)

\footnotetext{
1 Tradução de Donaldo Schüler (2002).

O mesmo valerá para as próximas citações de Finnegans wake em português, exceto quando indicado; de resto, citações diversas desacompanhadas da indicação de autoria são traduções livres feitas por mim.
} 
Decidir ler Finnegans wake é decidir por lançar-se ao texto.

Ainda que sua escrita tenha sido iniciada pouco tempo após a publicação de Ulysses (1922), que já despertara uma recepção que ia de manifestações de repúdio a grandes elogios, passando por problemas com censura e acusações de obscenidade, Finnegans wake (1939) foi publicado mais de dezesseis anos depois de o dublinense James Augustine Aloysius Joyce (1882-1941) começálo e por volta de dois anos antes de seu falecimento em Zurique, no dia 13 de janeiro de 1941. Nesse ínterim, acabou por ficar ofuscada a publicação de Pomes Penyeach (1927), livro que também foi escrito em um longo intervalo de tempo, de 1904 a 1924, apesar de - bem ao contrário das duas obras entre as quais está intercalado - consistir em treze curtos poemas. 
O contexto em que Finnegans wake foi produzido é permeado por algumas peculiaridades: além do longo tempo de escrita e reescrita, a publicação de fragmentos do que até então se chamava Work in progress possibilitou que Joyce já tivesse, enquanto ainda escrevia, concreta noção do impacto que sua produção final poderia causar - fosse entre quem a lesse; fosse entre quem não leu, mas ouviu falar; fosse entre quem começou a ler e desistiu; até os que leram, mas tiveram a sensação de não terem lido (talvez a mais comum no primeiro contato com o Wake).

Soma-se a isso o problema de visão de Joyce, decorrente de um quadro de glaucoma que se agravava cada vez mais, obrigando-o a passar por mais de dez cirurgias e a buscar consultas com médicos de diferentes lugares em busca de alguma melhora. Chegou ao ponto de não conseguir mais ler nada impresso, passando a ter de escrever em uma caligrafia enorme para conseguir enxergar melhor, usar um tapa-olho que ficou famoso em algumas de suas fotografias e ditar alguns trechos de fragmentos do Finnegans wake. O então jovem escritor Samuel Beckett chegou a fazer esse trabalho algumas vezes, ouvindo a citação de Joyce com apreço pela tarefa especial que executava. Além de ser uma das figuras mais próximas do já célebre conterrâneo, de quem recebeu alguns elogios especiais e chegou a ser tratado com rara intimidade, foi um de seus mais sinceros admiradores e mais ativos defensores. Os dois ficaram afastados por um período de cerca de um ano após um mal entendido que envolvia a filha de Joyce, Lucia Anna Joyce, que parecia ter se apaixonado pelo jovem irlandês que visitava seu pai, mas a relação dos dois escritores acabou por sobreviver ao ocorrido.

Joyce teve, em vida, numerosos admiradores que, como Beckett, apoiaram ativamente sua produção. Entre os nomes mais importantes daqueles que estiverem em alguma medida presentes na fase final de sua vida está o de sua mecenas, a inglesa Harriet Shaw Weaver (1876-1961), que se tornaria editora da revista The Egoist (anteriormente chamada de The Freewoman e The New Freewoman). Weaver estudou na London School of Economics e participou ativamente do maior movimento pelos direitos das mulheres no Reino Unido, Women's social and political union, que reivindicou o sufrágio universal, direito 
concedido somente em 1928 (décadas depois da fundação do grupo, em 1903, e mais de um século depois das primeiras reivindicações na Inglaterra, desde o início endossadas publicamente por alguns homens célebres). A revista The Egoist contava com Ezra Pound na seção literária e nela foram publicados Phénomenologie de la perceptiontrechos de Ulysses. Pound, por um tempo, teceu diversos elogios aos trabalhos de Joyce e também o apoiou, antes que começasse a mudar suas opiniões a respeito das empreitadas literárias do irlandês exilado, especificamente na fase final de suas obras, em especial diante de Finnegans wake, que Ihe pareceu um material por demais indigesto.

Outro importante nome é o de Sylvia Beach (1887-1962), proprietária da Shakespeare and Company — fundada em 1919 e apelidada por Joyce de Stratford-on-Odéon, em referência a Stratford-upon-Avon, cidade natal de Shakespeare, e à rue de l'Odéon, onde ficava a livraria - que publicou a primeira edição de Ulysses, em 1922, e Pomes Penyeach em 1927, além da coletânea de ensaios sobre o Wake, que ainda estava em construção, em 1929, Our exagmination round his factification for incamination of Work in progress. Beach apoiou e acompanhou boa parte da carreira de Joyce, ainda que algumas das empreitadas tenham lhe acarretado problemas: "I understood from the first that, working with or for Mr. Joyce, the pleasure was mine - an infinite pleasure: the profits were for him"2 (FLANNER, 1972 apud HALFORD, 2010). Os anos 1930 marcaram dificuldades econômicas, apesar da ajuda de amigos e simpatizantes da livraria, que formaram um grupo para ajudar a reerguê-la, o Les amis de Shakespeare and company. Em 1941, porém, com a invasão da França pelo Terceiro Reich, agravando a Segunda Guerra Mundial, os problemas se somaram e levaram-na à falência. Apesar de a relação entre Joyce e Beach ter se tornado célebre e a livraria ter sido centro de muitos encontros, conta-se que, ironicamente, o fechamento da livraria aconteceu pouco depois de Sylvia Beach se recusar a vender a última cópia de Finnegans wake a um oficial do totalitarismo nazista.

\footnotetext{
2 "Compreendi desde o início que trabalhar com ou para o Sr. Joyce o prazer era todo meu - um
} infinito prazer: os lucros eram dele." 
In late 1941, Shakespeare and company was forced to close shortly after Beach refused to sell her last personal copy of Finnegans wake to a Nazi officer. It was symbolically "liberated" in 1944 by Ernest Hemingway, but in fact the bookstore never reopened, though in the 1950s Beach gave an American named Whitman permission to open a bookstore under that name. (FARGNOLI, 2006, p. 352) ${ }^{3}$

Foram figuras importantes na fase final vida de Joyce o casal Eugene Jolas (1894-1952) e Maria McDonald (1893-1987), americanos residentes em Paris que editavam a revista literária experimental Transition, fundada por eles em 1927, em que foram publicados excertos de Finnegans wake ainda sob seu título provisório anterior, Work in progress, além de artigos sobre a obra de James Joyce. Conheceram-se por Sylvia Beach. A revista de ares inovadores e artisticamente progressistas se estabeleceu como referência na capital francesa, especialmente entre os anglófonos desterrados. A seguinte descrição de Eugene Jolas encontra-se na premiada biografia James Joyce, $(1959 ; 1989)^{4}$ escrita pelo norte-americano Richard Ellmann:

Homem sensível, procurava uma teoria da arte que também fosse uma filosofia de vid: pensava tê-la encontrado numa "religião da palavra", cujo ritual ele saturava com termos como "fantástico", "mântico" e seu neologismo "paramito". Só na arte se podia confiar, e confiar apenas se se abjurasse do externo em nome da imaginação. (p. 725)

Eugene Jolas foi um daqueles que mais apoiaram e defenderam a obra de James Joyce em sua época, tendo visto em Finnegans wake uma obra que seria forte e consistente âncora para o manifesto que publicou em 1929 na própria revista Transition, denominado "Revolution of the word", no qual discorria sobre novas formas de linguagem literária. Durante a década de 1960, já viúva, Maria se tornaria célebre, ainda, como presidenta do Comitê Americano de Paris

\footnotetext{
3 "No fim de 1941, Shakespeare and company foi obrigatoriamente fechada pouco tempo depois de Beach ter se recusado a vender sua última cópia pessoa de Finnegans wake a um oficial nazista. Foi simbolicamente "liberada" em 1944 por Ernest Hemingway, mas a livraria nunca foi reaberta de fato, apesar de, nos anos 1950, Beach ter permitido que um americano chamado Whitman abrisse uma livraria usando o mesmo nome."

${ }^{4}$ Em 1982, Richard Ellmann recebeu o James Tait Black Memorial Prize, na categoria biografia, um dos mais tradicionais prêmios literários britânicos.
} 
contra a Guerra do Vietnã, que foi censurado pelo governo francês poucos anos depois de sua fundação, em 1968.

Adrienne Monnier (1892-1955) foi mais uma das maiores apoiadoras de James Joyce em Paris. Abriu a livraria La maison des amis des livres em 1915, que ficava próxima de um dos endereços da Shakespeare and company (o da rue de l'Odéon, que originou o já citado apelido de Joyce de "Stratford-onOdéon"). Adrienne Monnier difundiu na França a obra literária do escritor norteamericano Ernest Hemingway em traduções para língua francesa e publicou, por um tempo, o periódico literário Le navire d'argent, que contava com Jean Prévost em sua equipe editorial. Uma das primeiras mulheres a ser dona de uma livraria, especialmente fundada por ela mesma, isto é, sem que tivesse sido herdada de família ou de um falecido marido, Monnier foi referência para Sylvia Beach, que abriu seu negócio quatro anos depois, construindo-se entre elas uma vasta parceria.

Ford Madox Ford (1873-1939), literato inglês, próximo de Ezra Pound, que também residiu em Paris e que inspirou um capítulo do autobiográfico $A$ moveable feast, de Ernest Hemingway, foi outra fonte de apoio com que Joyce contou. Ford editava a revista literária The transatlantic review em Paris e a publicava em Londres, pela editora independente Gerald Duckworth Overlook (hoje tão somente Duckworth Overlook, cujo slogan é "independente desde 1898"). Inicialmente, os financiadores da Transatlantic exigiram que nada escrito por Joyce fosse publicado na revista, mas acabaram abrindo mão da proibição quando Ford ameaçou recusar o cargo de editor. Com doze edições mensais durante o ano de 1924, foi a primeira publicação a conter excertos do então Work in progress - título virtualmente sugerido por Ford em seu suplemento literário, depois adotado por Joyce - que só mais tarde apareceriam também na Transition do casal Jolas. Ford, que também publicou Hemingway e Tristan Tzara, chegou a temer que sua revista fosse prejudicada se houvesse alguma acusação de obscenidade do que Joyce escreveu. Por outro lado, a princípio, o próprio Joyce se recusou publicar assim trechos de sua obra em andamento, por acreditar que não seria bom tê-la fragmentada (apesar de Ulysses ter sido 
publicado dessa maneira em outra revista, a Little review), tendo negado outros convites anteriores, mas acabou cedendo.

Tanto as várias publicações dos excertos em progresso quanto, posteriormente, a publicação de Finnegans wake, porém, fizeram com que até alguns de seus admiradores mais contundentes se manifestassem negativamente. Até mesmo Nora, a esposa de Joyce, criticou o texto do Wake, pejorativamente um "chop suey", questionando a qualidade a partir da ininteligibilidade. Reiterava assim a opinião expressa por Harriet Shaw Weaver, que também se posicionou desfavorável ao que Joyce estava produzindo no fim de sua vida, distanciando-se consideravelmente dele na fase em que estava escrevendo o Wake. Em uma carta a Joyce, disse abertamente não se interessar pela "produção de seu Atacado de Trocadilhos de Segurança nem pelas escuridões e ininteligibilidades do seu sistema de linguagem deliberadamente emaranhado. Parece-me que você desperdiça seu gênio" (ELLMANN, 1989, p. 728). Ainda que não tenha havido grande rancor entre os dois: na ocasião da morte de Joyce, em Zurique, ela teria arcado com as despesas de seu funeral que não teve refinamentos e nem qualquer homenagem ou contribuição vinda da Irlanda.

Ezra Pound (1885-1972) foi quem, possivelmente, fez o comentário mais ácido. O escritor norte-americano começou a tecer críticas desde os capítulos finais de Ulysses e, quanto a Finnegans wake, ao receber de Joyce o manuscrito do livro de Shaun para que lesse e comentasse, respondeu a ele que só the restava desejar sucesso, mas não sabia o que pensar. Na mesma carta, chegou a dizer que aquele texto só valeria a pena se apresentasse uma visão divina ou a cura para a gonorreia ("the clap"): "Nothing short of divine vision or a new cure for the clapp [sic] can possibly be worth all that circumambient peripherisation" 5 (READ, 1970, p. 228). Vale lembrar que, anteriormente, na ocasião de uma tentativa de angariar fundos para Joyce a partir do Royal Literary Fund, Pound se referiu a Joyce, escrevendo a Yeats e George Moore, de maneira muito

\footnotetext{
${ }^{5}$ A tradução feita por Lya Luft da biografia de Joyce escrita por Richard Ellmann traz a seguinte versão do trecho: "Nada até onde eu possa ver, nada sem visão divina ou uma nova cura da gonorreia valerá possivelmente a peripatetização circunambiente" (1989, p. 721).
} 
elogiosa, tendo expressado esses elogios também ao próprio Joyce, em outras ocasiões: "...still it gives me a certain satisfaction to state that I consider Joyce a good poet and, without exception the best of the younger prose writers... His style has the hard clarity of a Stendhal or a Flaubert... He has also the richness of erudition which differentiates him from certain able and vigorous but rather overloaded impressionist writers"6 (ELLMANN apud DENNING, 1997, p. 10).

A primeira publicação sobre Finnegans wake surgiu antes mesmo que a obra fosse concluída. Alguns apoiadores de Joyce se reuniram em torno da obra coletiva Our exagmination round his factification for incamination of Work in progress $^{7}$ (1929), quando ainda havia apenas os fragmentos denominados Work in progress, com o intuito de atenuar a recepção que até então oscilava nebulosamente. O título circular, sugestivo e bem-humorado, foi sugerido por Joyce. A coletânea foi publicada pela Faber and Faber, a mesma editora que publicou a primeira edição de Finnegans wake quase dez anos mais tarde, em 4 de maio de 1939. Reunia ensaios críticos de doze autores: Samuel Beckett, Stuart Gilbert, Eugene Jolas, Marcel Brion, Frank Budgen, Victor Llona, Elliot Paul, Robert McAlmon, Thomas MacGreevy, John Rodker, Robert Sage e William Carlos Williams. O próprio Joyce desejava que essa publicação não contivesse apenas textos elogiosos, mas também que se expressasse algo de negativo a respeito de seus escritos. Além dos doze artigos, houve dois textos extras, denominados "cartas de protesto" (letters of protest), e ambos trouxeram críticas: o de uma jornalista que assinou sob o pseudônimo de G. V. L. Slingsby e outro assinado por um poeta russo chamado Vladimir Dixon. O texto de Dixon, "A litter do James Joyce", denomina seu destinatário ora de senhor Germs Choice, ora de senhor Shame's Voice, trocadilhos que fizeram Stuart Gilbert e Sylvia Beach cogitarem que essa crítica negativa tivesse sido escrita pelo próprio Joyce. A hipótese, porém, permanece não confirmada.

\footnotetext{
${ }^{6}$ Tradução livre: “...ainda assim me dá certa satisfação afirmar que considero Joyce um bom poeta e, sem exceção, o melhor dos jovens prosadores. Seu estilo tem claridade dura de um Stendhal ou de um Flaubert. Ele tem, ainda, a riqueza da erudição, que o diferencia de alguns hábeis e vigorosos porém excessivos escritores impressionistas."

7 A mesma tradução supracitada propõe o título traduzido Nosso Exagme em torno da sua factificação da incaminação de Obra em realização (Ibid., p. 755).
} 
O tradutor inglês Stuart Gilbert (1883-1969), um dos nomes envolvidos na publicação, era um dos assíduos e atentos leitores contemporâneos de Joyce. Foi quem publicou James Joyce's Ulysses: A Study (1930), livro ainda hoje útil para consulta na leitura da obra que precedeu Finnegans wake, elucidando numerosas referências um tanto obscuras por todos os capítulos e incluindo, ainda, a famigerada tabela comparativa entre Ulysses e a Odisseia de Homero. Stuart Gilbert foi apresentado a Joyce por Sylvia Beach, assim como Maria e Eugene Jolas.

Apesar de conterrâneos, Samuel Beckett (1906-1989) e James Joyce se conheceram somente em Paris, no exílio da terra-mãe compartilhada, e logo se estabeleceu a rotina de que Beckett o visitasse sempre que estivesse na cidade. Por ter acompanhado boa parte do processo de criação de Finnegans wake, especialmente na ajuda que deu a Joyce por seus problemas de visão, podemos imaginar que Samuel Beckett era grande candidato a uma espécie de leitor ideal, o mais próximo do texto além do próprio autor. Suas observações sobre o livro de Joyce são brilhantes. É sabido que foi Beckett o primeiro (ou, ao menos, certamente um dos primeiros) a notar verdadeiramente que a incompreensão mais comum se traduz antes mesmo de a leitura ser iniciada, isto é, ainda ali, nas expectativas perante o livro - como poderíamos "entender" o Finnegans wake esperando uma leitura tradicional?

You cannot complain that this stuff is not written in English. It is not written at all. It is not to be read.... It is to be looked at and listened to. (...) Here form is content, content is form (...) His writing is not about something; it is that something itself... When the sense is sleep, the words go to sleep... When the sense is dancing, the words dance. (BECKETT, 1964, p.14)

\footnotetext{
8 "Não se pode reclamar que esse material não esteja escrito em inglês. Simplesmente não é um material escrito. Não existe para ser lido... Existe para ser olhado e ouvido. (...) Aqui forma é conteúdo, conteúdo é forma. (...) Sua escrita [de Joyce] não é sobre alguma coisa; é a própria coisa... Quando o sentido é adormecido, as palavras vão dormir... Quando o sentido é dançar, as palavras dançam."
} 
O que Beckett muito cedo percebeu e acaba por nos confirmar é que a linguagem em Finnegans wake não se presta a meramente servir ao remetimento, à descrição, nem a contar um ocorrido; prefere trazer nela em vez de apresentar por meio dela; intenta tê-la como ambiente próprio do acontecimento, não como ferramenta sígnica para dizê-lo representativamente, ou dizê-lo a distância. Levando essa tentativa em consideração, nada mais coerente do que dispensar a escolha de um idioma para produzir o texto, tecendo sua literariedade de maneira anárquica em relação a regras de formação de palavras ou quaisquer outras normatividades de um idioma e suas limitações, a ponto de se poder dizer que o Finnegans wake não está escrito em inglês, nem em irlandês, mas sim em uma língua própria, babélica - ainda que se possa argumentar que a base dessa subversão é a língua inglesa, de maneira que Joyce tanto escreve no inglês quanto contra ele, como já foi dito nas palavras do estudioso Seamus Deane:

\begin{abstract}
Joyce involves himself and us in an extremely complex series of translations that are endless because there is no original and no target language (...) the original language is the target language. The book is written in the English language and also against the English language; it converts itself into English and perverts itself from English. (DEANE, 2000, p. viii) ${ }^{9}$
\end{abstract}

Lendo uma obra que não pode oferecer certezas ou linearidades, estamos, em última instância, simplesmente nos entregando a ela, sem indícios que possibilitem saber ou prever minimamente no que tudo aquilo vai dar. $\mathrm{O}$ leitor só pode continuar sua empreitada se estiver ciente dessa ausência de sentidos pontuais e de sequências narrativas às quais normalmente buscaria se prender. Não há uma sequência de cenas causando a sensação de suspense ou de fluidez narrativa que nos faz virar as páginas em prosa comum. Ao invés disso, o livro todo é espécie de puro e constante suspense (uma descrição em si impossível para o significado de "suspense"), como se o caminho de seu texto

\footnotetext{
9 "Joyce se envolve e nos envolve em uma complexa série de traduções que são infinitas, porque não há língua de origem e língua-alvo. (...) a língua de origem é a língua-alvo. O livro é escrito em língua inglesa e também contra a língua inglesa; ele se converte em inglês e se perverte do inglês."
} 
virasse esquinas que os leitores nem mesmo tinham visto que existiam. Cada termo, cada linha do Wake contém diversas camadas semânticas que podem ser absorvidas em diferentes níveis e, assim, a leitura se realiza de uma forma única de acordo com as referências que o leitor captou. Essa configuração textual potencializa - ou polemiza - as diferenças que existirão entre leituras por pessoas diferentes ou entre as releituras de um mesmo indivíduo.

Por isso, decidir ler Finnegans wake é decidir por lançar-se ao texto. Lêlo é uma experiência fenomênica per se.

Mesmo para alguns leitores que dedicaram parte de suas vidas a lê-lo e relê-lo, o texto não se ausenta de dificuldades. Uma das primeiras publicações oferecendo uma leitura ampla e aprofundada da totalidade do Wake, que se propusesse a ter alguma didática em sua abordagem, foi $A$ Skeleton key to Finnegans wake, dos pioneiros Joseph Campbell e Henry Morton Robinson, em 1944. O inglês Anthony Burgess, lembrado por sua famigerada ficção distópica A Clockwork Orange (1962), e o acadêmico americano William York Tindall também foram alguns dos primeiros a publicarem guias completos para a leitura do Wake, além de Robinson e Campbell. Burgess publicou Here Comes Everybody: an introduction to James Joyce for the ordinary reader (1965), pela própria Faber and Faber; A shorter Finnegans wake (1967), que traz o texto de Joyce consideravelmente reduzido por Burgess, e Joysprick: na introduction to the language of James Joyce (1973). Tindall publicou A reader's guide to Finnegans wake (1969), que sucedeu seu outro estudo didático, de escopo mais amplo, A reader's guide to James Joyce (1955).

William York Tindall tenta tornar o processo de leitura o mais didático e facilitado possível, indicando as referências em cada capítulo do Wake. Ao final de sua introdução em $A$ reader's guide to Finnegans wake, Tindall afirma que seu guia não visa a uma apreensão completa nem a ultimatos sobre a obra, mas sim a ser um suplemento de estudos prévios e acompanhar a leitura de uma maneira relativamente independente, isto é, livremente: "After all, what authority on the Wake knows half of it? Which half is the critical question" (TINDALL, 1969, 
pp. 25-26) ${ }^{10}$. Ironizar a possibilidade de que se saiba afirmar algo sobre Finnegans wake talvez se aplique, em verdade, a qualquer texto literário, mas William York Tindall se resguarda, claro, especificamente, em sua condição de joyciano e de redator de um guia para o Finnegans wake. Diz, ainda, nessa mesma introdução:

Surely, the Wake abounds in farcical materials (...). But farce is a category of drama, and, except from dream maybe, the Wake evades categories. There's 'lots of fun at Finnegan's wake', says the poet in his ballad of Tim Finnegan. Taking my clue from this, distrusting categories as I distrust earnestness, I content myself with calling the Wake a very funny book. (Ibid., p. 20) ${ }^{11}$

De fato, o humor é uma das características sobressalentes em Finnegans wake. Os puns frequentemente carregam uma ironia inevitavelmente risível. Entre absurdos e alfinetadas, a coletânea de trocadilhos ruma ao riso. Uma das comparações mais acertadas - ainda que comparações sejam sempre perigosas - foi feita pelo escritor francês Valery Larbaud, falando de Ulysses: "é tão grande e abrangente e humano quanto Rabelais" (ELLMANN, 1989, p. 617). Esse algo de rabelaisiano povoa ainda mais o sucedente Finnegans wake, que pretende tudo abarcar, trabalha sobre o aparente exagero - que perde a característica de excesso ao se fazer produtivo. $O$ exagero leva ao humor, o inacreditável e inverossímil levam à quebra imediata e incontornável da seriedade. O que Wake tem de excessivo pode ser para nos fazer rir mais do que para impressionar presunçosamente ou para meramente dificultar o texto ou adorná-lo; mais que isso, o que o texto faz é lotar a si próprio, isto é, se estufar de conteúdo, com um barroquismo que se autoironiza.

\footnotetext{
10 "Afinal de contas, qual autoridade no Wake conhece sequer metade dele? Qual metade é a questão crítica."

11 "Certamente, o Wake se aproxima de materiais farsescos (...). Mas a farsa é uma categoria do drama e, exceto por sonho, talvez, o Wake se esquiva de categorias. Há 'muita diversão no funeral do Finnegan', diz o poeta em sua balada sobre Tim Finnegan. Tirando daí uma pista, desconfiando de categorias como desconfio de seriedade, eu me contento com chamar o Wake de um livro muito engraçado."
} 
Em artigo de 1955, "A obra de arte aberta", posteriormente publicado em Teoria da poesia concreta (1965), Haroldo de Campos buscou compreender as direções para as quais apontavam as obras de arte modernas e, para percorrer esse caminho, partiu de Finnegans wake e de obras de diversos autores Mallarmé, Ezra Pound, Cummings, Pierre Boulez, Décio Pignatari e outros. Em Opera aperta (1962), Umberto Eco aborda o tema de maneira similar: também fundamentou seu paradigma de obra de arte aberta a partir de Finnegans wake e outras obras. ${ }^{12}$ Havia uma seção toda dedicada a Joyce na primeira edição, que depois passou a ser editada separadamente e consistia em uma

primeira tentativa pessoal de acompanhar o desenvolvimento de um artista no qual o projeto de uma obra aberta manifesta em transparência, ao nível da pesquisa das estruturas operacionais, toda uma aventura cultural, a solução de um problema ideológico, a morte e o nascimento de dois universos morais e filosóficos (ECO, 1988, p. 22)

Haroldo de Campos e Umberto Eco, falando da "obra de arte aberta", não foram os únicos a derivar do Finnegans wake de Joyce compreensões e premissas de um grande paradigma teórico. Joseph Campbell (1904-1987), teórico estadunidense, elaborou o célebre conceito de monomito, segundo o qual a jornada de um herói é cíclica e essa característica poderia ser notada em todas as mitologias, em diferentes graus, tomando como exemplos mitos que compõem a mitologia hindu, egípcia, grega e cristã. Joseph Campbell parte da tese de que todos esses mitos são variações de uma mesma narrativa una. Um dos padrões que Campbell estudou nessas variações foi a jornada do herói, descrito em The hero of a thousand faces (1949). A primeira publicação de impacto de Joseph Campbell foi justamente já citado estudo pioneiro entre as

\footnotetext{
12 Não são necessariamente abordagens idênticas, apesar da grande coincidência entre ambas, inclusive terminológicas. O próprio Umberto Eco, em introdução à edição brasileira, diz: "É mesmo curioso que, alguns anos antes de eu escrever Obra Aberta, Haroldo de Campos, num pequeno artigo, lhe antecipasse os temas de modo assombroso, como se ele tivesse resenhado o livro que eu ainda não tinha escrito, e que iria escrever sem ter lido seu artigo. Mas isso significa que certos problemas se manifestam de maneira imperiosa num dado momento histórico, deduzem-se quase que automaticamente do estado das pesquisas em curso" (ECO, 1988, p. 17).
} 
publicações sobre o Wake, A skeleton key to Finnegans wake (1944), escrito por ele em parceria com Henry Morton Robinson e publicado pela editora Harcourt, então Harcourt Brace. Foi certamente o primeiro estudo completo e que se propunha a servir como guia de leitura, mais de duas décadas antes de Tindall publicar o seu famoso A reader's guide. A obra de James Joyce gerou inspiração para Campbell até mesmo na escolha do termo: "And his monomyth! Ah ho!" (FW, 581.24). As ideias desenvolvidas no conceito são bastante caras ao Finnegans wake: muitas variações temáticas reunidas, formando uma unidade, um caleidoscópio dos grandes mitos em que as narrativas histórias se entrelaçam ao invés de somente se diferenciarem entre si. Apagam-se as linhas que delimitam a identidade cultural, o idioma, a língua nacional ou regional, o momento histórico ou qualquer porção isolada de tempo e espaço; tudo age em prol da compreensão do todo e do que nos une através dos séculos e das fronteiras.

No Brasil, a recepção de Finnegans wake e sua influência no trabalho de grandes intelectuais também não tardou a se explicitar - e com grandes leitores/leituras: alguns fragmentos foram traduzidos por Augusto de Campos e Haroldo de Campos em Panaroma do Finnegans wake (1962). Essa publicação foi de enorme importância na difusão do texto no Brasil, em uma via de mão dupla: tanto Joyce influenciou intelectuais ligados à poesia concreta, quanto os irmãos Campos contribuíram para difundir ainda mais a sua obra. Felizmente, não houve grande impacto negativo que afastasse leitores e parecesse invalidar a qualidade do Wake; ao contrário, a recepção foi não só positiva como especialmente produtiva, em especial graças à publicação do Panaroma do Finnegans wake, que encorajou certa inspiração e aproximação da obra com o que se fazia no Brasil em termos de poesia, tradução e até mesmo música ${ }^{13}$ já nos anos 1960.

13 É relativamente desconhecido o fato de que Péricles Cavalcanti musicou um trecho do Panaroma do Finnegans wake traduzido por Augusto de Campos, "Nuvoleta", mas essa bela versão pode ser conhecida online numa performance com Regina Casé de 1983, no Sesc Pompeia, para o programa Fábrica de Som. 
Há, ainda, poucas (ou talvez seja um número surpreendentemente alto) traduções extensas de Finnegans wake publicadas mundo afora - francês, alemão, mandarim, polonês, japonês (há duas), coreano, italiano, galego... contam-se nos dedos - , e o português, há poucos anos, foi incluído entre os poucos idiomas que possuem tradução integral graças a Donaldo Schüler, que traduziu o texto do Wake para o português brasileiro (se é que seria coerente dizer dessa maneira, enquadrando em um idioma) no decorrer de quatro anos. A tradução, cujo primeiro volume data de 2001, foi publicada aos poucos e trouxe consigo o título cunhado pelos irmãos Campos, Finnícius revém. Com notas de leitura a cada capítulo, que comentam aspectos gerais do texto, Schüler realizou essa tarefa hercúlea com vasto mérito e deixou sua contribuição crítica unida ao seu trabalho de tradução.

Houve, em especial, nos anos 2000, uma revisitação de toda a tradição de Joyce e uma espécie de nova recepção sua no Brasil, com muitas traduções e trabalhos diversos sendo publicados. Uma terceira via de tradução foi executada com Ulysses (2012) por Caetano W. Galindo, que também traduziu Finn's Hotel (2014). Este último se trata de textos que antecederam a finalização do Work in progress que se tornaria o Finnegans wake. Permaneceu em suspenso se o Finn's hotel de Joyce deveria ser um livro independente e ele acabou por descartá-lo ou se eram rascunhos, ensaios, tentativas ou algo semelhante do que planejava fazer em sua obra final, já que o livro abarca muitos elementos do Wake. Recentemente, também, alguns dos escritos esparsos de James Joyce foram editados em De santos e sábios: escritos estéticos e políticos (2012), organizado a partir de The critical writings por Dirce Waltrick do Amarante e Sérgio Medeiros; ambos fizeram também a tradução e organização de Cartas a Nora (2012), que possuem tradução portuguesa editada no mesmo ano, feita por José Miguel Silva; ainda no mesmo ano, foram publicadas também as Epifanias (2012) de Joyce, traduzidas por Piero Eyben; anteriores, ainda, são o livro-guia Para ler o Finnegans wake de James Joyce (2009), de Dirce Waltrick do Amarante, que traz também uma tradução do fragmento Anna Livia Plurabelle, e O efeito da letra: Lacan leitor de Joyce (2003), de Ram Mandil. 
Expusemos, então, de maneira brevíssima, a recepção de Finnegans wake da maneira como se deu inicialmente, em especial no seu impacto entre as figuras centrais da vida de James Joyce como escritor - que contrasta, como pontuamos, com a maneira como o Wake chegou ao Brasil, se estabelecendo não muito tardiamente como referência e influência tanto para alguns de nossos maiores intelectuais quanto para um público geral e de diversas áreas. A intenção, de uma maneira ou de outra, não é, sublinhe-se, a de reiterar as dificuldades de acesso ao texto, já que muitas das objeções citadas por contemporâneos de Joyce partem do argumento de uma suposta profunda e contraproducente inteligibilidade, bem como da noção de que sua obra final seria um jogo louco ou inútil de palavras e sons.

Ao contrário, pode ser relevante conhecermos ao menos alguns dados sobre a recepção turbulenta para sabermos enfrentar esses argumentos já velhos, enferrujados, que intentam justificar por que não ler Finnegans wake e ainda surgem com espantosa frequência. Como respondê-los hoje? Ainda se acredita que Finnegans wake é uma piada, um sarro, um jogo intelectual banal e mais pretensioso do que primoroso? Ainda é visto como um texto impenetrável? Por quê? Até quando? Quais as consequências de uma obra como essas ser considerada "um livro que ninguém leu/lê" considerando, ainda, os avisos ou receios dos que dizem que, em geral, lê-se cada vez menos literatura? Como Finnegans wake é considerado clássico (se o for) se é ilegível e impenetrável e/ou uma peça de chacota intelectual? O que seria um clássico e de que vale essa classificação valorativa?

É claro que não faria sentido negar as peculiaridades inerentes ao texto e à sua construção, e nem pretendemos fazê-lo; pretendemos o exato oposto desse reducionismo, que é enxergá-las e enfrentá-las da maneira mais destemida possível - destemida no sentido de não criar diferenciações entre literatura "fácil" e "difícil"; leia-se, sem criar uma categoria especial para a leitura do Finnegans wake. Não se trata de afirmarmos que seja um texto "fácil", nem que seja um texto impenetrável. Ideal é que o encaremos como o que ele é um texto literário, um texto escritural, como quisermos chamá-lo: é um texto. Demanda-nos a leitura. De nós, leitores, quaisquer que sejamos. Se olhamos 
para o Wake e questionamos o que contém, já somos grandes candidatos a percorrer seus caminhos. Não são muitos os dispostos. Não porque devam ser selecionados, mas porque os preconceitos talvez afastem os desinteressados. Ulysses já carrega também certo estigma, mas parece figurar como uma obra um tanto mais simpática ou atraente, quiçá mais receptiva, ainda que considerada também difícil, extensa, complexa. Ulysses tem três traduções brasileiras ${ }^{14}$, de três intelectuais, de diferentes épocas, de mérito e de peso, de fundos distintos e, consequentemente, trabalhos tradutórios também (felizmente) diferentes entre si, o que também colabora para multiplicar nossas possibilidades de fontes e referências durante a leitura. Sua dificuldade parece ser menos alvo de piadas do tipo "mas ninguém lê...", ainda que, curiosamente, não haja guias elaborados e nem mesmo traduções brasileiras de guias de leitura especificamente voltados para Ulysses ainda, enquanto já temos Para ler 0 Finnegans wake de James Joyce (2009).

Apontar problemas ou tecer críticas diversas à construção textual de Finnegans wake, como foi mostrado, não foi exclusividade dos absolutamente conservadores, ao menos artisticamente falando. Diante da radicalidade do texto e da aparente incompreensibilidade, era como se um estranhamento imediatamente tomasse o possível leitor, mesmo que este fosse alguém relativamente (ou mesmo bastante) aberto. Como vimos, os exemplos são muitos, de artistas como Ezra Pound ("A receptividade de Pound à inovação tinha seus limites, como Joyce agora sabia"; ELLMANN, 1989, p. 722), de sua parceira próxima Sylvia Beach, até mesmo de alguns parentes, como sua esposa, Nora, sempre fonte de apoio e companheirismo, e seu irmão, que também era escritor. Foram variadas as reações, mas especialmente numerosas as reações negativas, chegando a atingir emocionalmente Joyce em alguns momentos.

\footnotetext{
${ }^{14}$ A saber, a de Antônio Houaiss (1966); a de Bernardina da Silveira Pinheiro (2005) e a mais recente, de Caetano Galindo (2012), premiada pela Academia Brasileira de Letras e pela Associação Paulista de Críticos de Arte, além de ter recebido o Prêmio Jabuti de melhor tradução do mesmo ano.
} 
A fama de Finnegans wake que se espalhou pelo mundo (e permanece até os dias de hoje, contaminando a visão que normalmente se tem do livro de preconceitos, uma vez que quase sempre precedem a sua leitura), de que é um livro impenetrável e/ou uma grande piada de James Joyce, ou de que é nada além de um livro propositalmente dificílimo e insano não acabará de repente. $O$ que preocupa é o "nada além". Que se tome Wake como paradigma de livro complexo é aceitável e até pertinente; que se deixe de lê-lo tendo em conta esse tipo de estigma, porém, passa a ser uma subestimação e pode ser, de alguma maneira, uma perda real. Felizmente, no Brasil, como vimos, existe cada vez mais um número de publicações sobre Joyce que vem crescendo e se ampliando tanto quanto vem se aprofundando com diferentes leituras. A recepção atribulada de que fizemos um panorama, no entanto, desde as primeiras reações à obra final de James Joyce, mesmo entre aqueles que o admiravam e acompanhavam seu trabalho, aponta para algo que está no cerne das considerações desta pesquisa: o que o Wake tem de tão deslocado, tão marginal, sendo ao mesmo tempo tão célebre? O objetivo é fazer dessa compreensão algo produtivo.

Pois bem: se é um livro ilegível, não se poderia escrever um trabalho acadêmico sobre ele (ou, em algumas visões do que é um trabalho sobre literatura, justamente por isso fazê-lo seria necessário e sugerido, ironicamente...). A concepção de legível é a que deve ser posta em xeque aí em primeiro lugar, ou, ao menos, antes de se questionar se Finnegans wake o é ou não. Isso se faz especialmente necessário se falamos de legível referindo-nos à literatura, como se houvesse um processo de alfabetização específico. No entanto, mesmo que se pare de olhar para o Wake apenas observando esse seu caráter superficial, arriscamo-nos a dizer que sua impenetrabilidade, por si só, diz alguma coisa. A maneira como se encara a conceituação de obra literária desde a assunção dessa possibilidade até o processo de efetivamente conceituá-la - certamente tem implicações no processo de aceitação ou de recusa diante de uma obra específica, bem como na ação crítica de valorar e de julgar. 
Ora, se uma coisa não se encaixa no que se espera dela, algo não está nas medidas esperadas: ou a coisa, ou o molde, isto é, a fôrma, com suas medidas limitadas e exigências de enquadramento. Se a obra é algo que se deva encaixar em uma concepção de literatura que a antecede e normatiza as produções literárias, em uma hierarquia duvidosa que cria uma governança de cima para baixo, do molde para a coisa, é compreensível toda a resistência que foi criada frente ao Finnegans wake.

O que essa má recepção que ecoa até hoje em estigmas diversos normalmente aponta, portanto, é que o problema ou o defeito está na obra de Joyce, levando em conta esse procedimento normativo de interpretação e de julgamento e critica da literatura. $O$ que propomos é que o problema esteja, talvez, no molde. 
Capítulo I:

WAKE EM PAUTA 
1. Algo parecido com nada

A recepção negativa ou perplexa diante de Finnegans wake, como vimos, foi ampla a ponto de certa má reputação ultrapassar o teste do tempo, permitindo que sobrevivessem estigmas relacionados à obra até os dias de hoje, causando ranço mesmo entre literatos e afastando possíveis leitores por entre as décadas. Ulysses foi um (anti)romance aclamado, ainda que também tenha tido uma recepção controversa e resultado, poucos anos depois de sua publicação, em uma série de processos contra Joyce e na proibição de sua circulação nos Estados Unidos e no Reino Unido sob a acusação (hoje, risível) de conter pornografia. Também significou uma reviravolta naquilo a partir de que se definia mesmo um "romance", suscitando hesitação, impaciência e reprovação, mas acabou por selar a fama de Joyce em vida, traduzida inclusive em alguma segurança financeira, mesmo que temporária. 
No caso de Finnegans wake, no entanto, a sua fama, paradoxalmente, foi o motivo de seu relativo ostracismo. Quando já estava viúva, Nora Barnacle, que não se interessava tanto por literatura e não se sentia exatamente atraída pela convivência com artistas, tampouco por conversas literárias, além de eventualmente deixar Joyce magoado por não ler o que ele escrevia, chegou a perguntar a Maria Jolas: "Por que falam tanto no Ulysses? O Finnegans wake é o livro importante. Quando é que você e Eugene vão escrever sobre ele?" (ELLMANN, 1989, p. 912). Como é sabido, até mesmo contemporâneos entusiastas da obra joyciana, que não Ihe poupavam elogios, tiveram opiniões controversas a respeito da obra de máxima radicalidade, na qual Joyce teria conseguido engendrar uma inovação tanto formal quanto de conteúdo ainda maiores do que em suas produções anteriores.

Seu irmão mais novo, Stanislaus Joyce (1884-1955), com quem mantinha contato e se correspondia mesmo com as constantes mudanças de residência entre países, escreveu-lhe em 1924 dizendo que havia lido "seu romance ainda sem nome na transatlantic review" (Ibid., p. 712). Reitera que, em geral, gosta muito do predecessor Ulysses, ainda que não tenha paciência nem humor para alguns trechos, mas aponta que há uma ou outra parte "inesperadamente terna" e comovente. Sobre o Finnegans wake, no entanto, a impressão é outra, e Ihe parece que muitos agora o elogiam por bajulação, deixando Joyce mimado demais. Cita um artigo de Ford Madox Ford, cuja leitura foi indicada a ele pelo irmão, em que Ford sugere que se encare o Work in progress "como um ritmo nonsense e que o leitor deveria abandonar-se ao seu balanço". No entanto, Stanislaus não parece se convencer: "Tenho certeza, embora o artigo pareça ter a sua aprovação, de que ele fala sem saber o que diz" (Ibid., p. 713). Por sua vez, afirma que não entendeu muito do que leu, tampouco se interessou verdadeiramente. Citando a publicação de Herbert Gorman, James Joyce: The first forty years (1924), que atribui a Joyce "a última palavra em literatura moderna", elucubra que isso talvez signifique algo mais literal e escatológico para a literatura: 
Pode ser a última palavra noutro sentido, a insensata errância da literatura antes de sua extinção final. Não que eu imagine que a literatura vá morrer algum dia, enquanto os homens falarem e escreverem. Mas podem cessar de ler ou pelo menos de ler tais coisas. Eu, de minha parte, não leria mais que um parágrafo daquilo, se não conhecesse você. (...) Por que você continua inteligível e sincero nos versos? Se a literatura deve se desenvolver ao longo das linhas de sua obra mais recente, ela certamente se tornará, como Shakespeare aludiu há séculos passados, algo parecido com nada. (Ibid., pp. 712713)

Além da já exposta incompreensão e/ou desinteresse que os excertos de Finnegans wake causaram nos leitores, mesmo naqueles que eram próximos de James Joyce e que já nutriam admiração por seu trabalho, o que nos chama a atenção é a reflexão direta de Stanislaus - que era, assim como o irmão mais velho, um literato, mantinha anotações sobre literatura e arte e escreveu três livros sobre Joyce, Dublin e literatura, dois deles publicados postumamente ao deparar-se com a existência daquele texto, sobre o próprio destino da literatura. A maneira como ele enxerga a radicalidade de Finnegans wake Ihe diz que, se ela passasse a ser constituída cada vez mais por obras como essa, poderia ter a sua existência ameaçada, ou ao menos os seus pilares fortemente balançados. Levantando a hipótese de que o número de leitores diminuiria cada vez mais, atribui a culpa da "tendência ao nada" ao próprio texto, afastando as pessoas por sua aridez. Não se trata simplesmente de uma mudança no entendimento de gênero, nem de inovações estruturais e formais (que demonstrariam uma contribuição ou uma destruição parcial ainda dentro da literatura): de alguma maneira, Finnegans wake ou acabaria com a literatura, ou ficaria à margem dela.

Joyce, porém, tinha a consciência de que seu projeto inevitavelmente envolvia um caráter, em algum nível, obscuro ou embaçado, certamente de difícil compreensão imediata, mas confiava, com algum otimismo, na possibilidade de que os leitores atravessariam as dificuldades do texto e admirariam o que ele sistematizou. Dizia claramente que "o mundo da noite não pode ser representado na linguagem diurna" e "Para Claud Sykes, insistiu: "É tudo tão simples. Se alguém não entende uma passagem, tudo o que precisa é ler em voz alta" (Ibid., p. 729). 
Não parecia concordar, portanto, com a preocupação que alguns the expressavam a respeito do caráter ou mais, ou menos literário de sua obra. Ao contrário, parecia entender que, sim, era uma obra muitíssimo distinta, mas que trazia consigo algo de grandioso por si e em si, não necessariamente grandioso pela razão de quebrar paradigmas, muito menos o início de uma "nova" literatura toda pautada em seu estilo. Augusto de Campos, em "Outras palavras sobre Finnegans wake", aponta a reação do escritor irlandês a essas provavelmente inesperadas críticas de seu, digamos, ex-admirador (termo um tanto forte, porém relativamente fiel ao que aconteceu) Ezra Pound, bem como sua defesa diante das acusações de ininteligibilidade:

\begin{abstract}
Mas Joyce não se deixou desencorajar pelas objeções de Pound (ao qual replicou, obliquamente, com trocadilhos e alusões no próprio Finnegans wake). "É possível que Pound tenha razão", escreveu a Harriet Shaw Weaver, em 1927, "mas eu não posso voltar atrás". Como esclarece Forrest Read, o escritor se defendia das acusações de obscuridade que Ihe faziam à época, argumentando: "Uma grande parte da existência dos seres humanos se passa em um estado que não pode ser tornado sensível pelo uso da linguagem 'de olhos abertos”, uma gramática pré-fabricada, um enredo linear. (CAMPOS, 2001, p. 195)
\end{abstract}

Por mais complexo que seja o texto de Joyce e por mais controversa que tenha sido a sua recepção, o supracitado guia $A$ skeleton key, de Joseph Campbell e Henry Morton Robinson, foi publicado apenas cinco anos depois da publicação integral de Finnegans wake, demonstrando leitura de considerável aprofundamento vertical e a percepção de inúmeras referências presentes na obra em um período relativamente curto de tempo. $\mathrm{Na}$ introdução, denominada "Introdução a um assunto estranho" (que foi traduzida para o português por Augusto de Campos e publicada na edição mais recente do Panaroma do Finnegans wake, de 2001), os autores de $A$ skeleton key alertam o leitor ingênuo ou temeroso a respeito do que se encontrará na obra magna de Joyce, sem negar a existência de algumas dificuldades nesse percurso. Apontam explicitamente para o terreno árido com que se defrontará o leitor; conseguem fazê-lo, porém, de forma que, apesar da honestidade ao dizer e ao pesar os 
obstáculos, prevaleça um tom positivo e mesmo uma espécie de convite direto a essa jornada literária incomparável sobre a qual escolheram desenvolver um estudo de alguma maneira democratizador.

\begin{abstract}
O vasto desígnio e a intrincada estrutura de Finnegans wake dão ao livro um aspecto proibitivo de impenetrabiidade. À primeira vista, parecemo-nos defrontar com uma selva densa e enganosa, ínvia e recoberta por luxuriantes perversidades de forma e linguagem. (...) Empreita a imaginação, exige disciplina e tenacidade dos que querem segui-lo na aventura. Contudo, algumas das dificuldades desaparecem desde que um leitor bem disposto encontre alguns pontos cardeais e acerte o rumo. Então o imenso mapa de Finnegans wake começa lentamente a desdobrar-se, emergem as figuras e os motivos, os temas tornam-se reconhecíveis, e o ouvido vai-se familiarizando cada vez mais com o vocabulário de Joyce. Não se espere alcançar um entendimento completo num primeiro e ávido embate; na verdade, pode-se não lográ-lo nunca. (CAMPBELL; ROBINSON, 2001, p. 152)
\end{abstract}

Joyce ouviu mais de uma vez que sua obra final não era ou não fazia parte da literatura. Pelo menos duas dessas ocorrências estão documentadas em sua biografia, como duas ocasiões em que o parecer foi quase idêntico. A primeira foi na leitura de um fragmento frente a um grupo pequeno de amigos, em que, tendo sua opinião requisitada por Joyce, a irlandesa Mary Colum respondeu: "Joyce, eu acho que isso está fora da literatura" (ELLMANN, 1989, p. 782). Na outra ocasião figura uma inglesa, que nos permanece anônima. Ela ouviu Joyce lendo um trecho e, supostamente, disse apenas: "Isso não é literatura". Segundo registra o biógrafo Richard Ellmann, Joyce respondeu "Foi", "querendo dizer que fora enquanto ela escutava" (Ibid., p. 865).

O problema não está no texto de James Joyce, mas no que se espera de um texto literário. Propor uma nova fôrma, no entanto, parece-nos inútil, porque não estamos pensando somente no que abarcaria Finnegans wake: afinal, que formatos abarcam a literatura? Se inventássemos os moldes sob medida, após uma extensa pesquisa e numerosas releituras, não teríamos nada além de um molde não para "literatura", mas para o Wake. Quando nos propuséssemos a ler qualquer outra obra literária, é certo que nos depararíamos com outras 
dificuldades e, então, o molde já estaria inutilizado novamente. Tentaremos, então, operar a leitura que não busca generalidades ou padrões, nem constrói guias idealmente universais. É claro que, produzindo uma dissertação e investigando a relação entre o que a teoria espera do livro e o que o livro entrega à teoria, esse intercâmbio será, em alguma medida, necessário; no entanto, o ponto central não é ler o Wake a partir de alguma teoria ou a partir de alguém. $O$ método aqui parte do lançar-se ao texto: ler Finnegans wake. Ponto. Método antimetódico.

Conta-se que James Joyce disse "com um sorriso cândido" para o poeta e ativista americano Max Eastman (1883-1969): "A exigência que faço para o meu leitor é que ele devote sua vida inteira a ler meus livros" (ELLMANN, 1989, p. 865). Relevando-se o possível exagero da expressão "devote sua vida inteira", ainda que se referisse, certamente, à crescente complexidade que suas obras apresentavam, Joyce gostava mais de saber que era lido do que de necessariamente ser elogiado, ainda que a incompreensão o desanimasse (e que ser lido por mais pessoas significasse um risco maior de ser incompreendido). Outra frase ainda mais hiperbólica é a famosa definição de leitor ideal, que seja aquele que "sofra de uma insônia ideal" (ld.).

Um possível pedantismo por trás do tom jocoso é anulado por diversas outras declarações, como as que se referem a Finnegans wake como tão somente um livro divertido - o oposto do que a famosa declaração de que foi escrito "para manter os críticos ocupados por trezentos anos" (Id.): "Eu sou apenas um palhaço irlandês, um grande piadista do universo", disse certa vez ao escritor francês Jacques Mercanton (1910-1996) e, respondendo a uma pergunta de Terence White Gervais (1913-1968) sobre o Wake ter níveis de significado, disse: "Não, não. É feito para fazer você rir" (ld.). Qualquer que seja a função proeminente no Wake, seja a de divertir, seja a de ocupar críticos - ou ambas —, parece-nos absolutamente incogitável que qualquer autor que trabalhe por anos a fio em uma obra prefira não ser lido, e é acima de tudo o compromisso de lermos Finnegans wake aquilo com que nos comprometemos aqui. 
O ponto central dessa tentativa se desenlaça em torno da questão do tempo, tomando-o não apenas como instância literária, mas também filosófica, perpassando discussões da metafísica de diversas épocas, também sem a concentração no conceito de tempo para algum filósofo específico. A escolha desse tema se justifica facilmente para aqueles que sabem um pouco sobre como Joyce concebeu sua última obra, sabendo da relevância da filosofia do italiano Giambattista Vico em sua construção, com a ideia de temporalidade constituída pela divisão de três Idades mais o ricorso, bem como sobre a problemática de se entender a cronologia da narrativa (ainda veremos se é possível falar em "cronologia" e mesmo em "narrativa"). Ainda assim, pretendemos investigar para além do paradigma de Vico, talvez vislumbrando o que impede, afinal, que Finnegans wake seja encarado como qualquer outra obra literária, ou apenas como mais uma obra literária difícil, como outras também o são. Note-se aqui a diferença entre um livro qualquer e um livro como qualquer outro; não é que o desejado seja considerar Finnegans wake como um livro qualquer, é claro. Mas que seja considerado, pelo menos, legível e divertido como Joyce o considerou e tantos leitores também o consideram, ao invés de se perpetuar como um mito de livro que nunca é lido e, pior, como um livro defeituoso, já que não facilmente compreendido segundo os moldes da teoria literária. O que percebemos é que talvez ele seja considerado de difícil compreensão especialmente nos casos em que o leitor o encara tendo uma série de expectativas relacionadas a uma visão tradicional de literatura, assim como acontece também, de uma outra maneira, com Ulysses.

Se confirmamos a hipótese de que seja possível e até mesmo desejável uma ruptura dessas expectativas, ou ao menos uma maior libertação delas, pode ser que se torne finalmente possível que mais leitores ganhem um novo desafio de leitura, que poderão constatar como efetivamente repleto de fruição, não apenas de operação cognitiva casmurra e tediosa. $A$ isso se combina a ideia de literatura concebida por Maurice Blanchot, evocada em Escritura do retorno: Mallarmé, Joyce e o meta-signo, a respeito dela como experiência-limite: "Ler, no espaço literário blanchotiano, é compreender as variações de um devir sempre futuro do leitor - como uma vicissitude do tempo, que é a própria obra" 
(EYBEN, 2012, p. 242). Nessa concepção, a leitura é "uma escritura interminável: vertigem da noção de espaço" (Ibid., p. 243). A leitura com a qual afirmamos assumir um compromisso é inscrita nesse entendimento escritural, em que ler não é simplesmente decodificar, evidentemente, mas também não é realizar uma hermenêutica, uma busca por verdade do texto e nem uma facilitação do desbravamento do texto joyciano, que se apresenta de uma forma específica a cada leitor/a - e, inclusive, a cada leitura, no sentido de fazer-se sempre novo.

\section{Suigeneris}

O questionamento sobre o gênero, que muito recorrentemente se impõe, constitui uma problemática já levantada desde Ulysses e seu tal caráter de antirromance ${ }^{15}$. A dificuldade de inserir Finnegans wake em uma definição desse tipo é absolutamente clara e redundantemente lembrada. O ponto mais perigoso das investigações dessa natureza é o fato de que esse alhures inominado em que se insere a obra final joyciana pode induzir o candidato a leitor à armadilha de rejeitá-la ou diminui-la pelo que ela tem de avesso às possibilidades de categorização - assumindo, absurdamente, a teoria como a entidade regente superior à matéria sobre a qual se teoriza. Com esse entendimento não raro, consideram-se as obras meros objetos que, se não se sujeitam a alguma fôrma e nem são capazes de gerar novas categorias, devem, por essa lógica, ter algo de mal estruturado, ou têm melhor destino sendo ignoradas. Isso ocasionalmente se dá, entre teóricos da literatura, de forma relativamente análoga ao que acontece quando gramáticos consideram o conjunto de regras da gramática normativa de um idioma como aquilo que rege e direciona o que deve ser levado em conta na língua, ignorando que esse conjunto de regras é, na verdade, obviamente restrito e derivado em percurso convencional da matéria

\footnotetext{
$15 \mathrm{O}$ termo, que aqui usamos pela segunda vez (a primeira com o prefixo entre parênteses), parece ser posterior a Joyce. Deriva de anti-roman (francês)/anti-novel (inglês). De qualquer maneira, só sintetiza o que já se dizia sobre o romance ter acabado com Ulysses. Joyce não deve ter sido o primeiro autor a suscitar esse tipo de comentário: o mesmo se disse, de outras maneiras, de Gustave Flaubert e Henry James.
} 
que o precede. Sendo uma língua algo mais amplo, variado e mutável do que a gramática normativa jamais conseguirá abarcar, mesmo em seus mais longamente descritivos ímpetos, é uma insanidade sobrepor a ela a normatização, assim como também é insensato desconsiderar Finnegans wake pelo que tem de inclassificável — ou, dir-se-ia, de indomável, incompreensível, inacessível -, algo que muito frequentemente se deu desde o início da publicação de seus fragmentos como Work in progress.

Enquanto Ulysses é o livro do dia, Finnegans wake é o livro da noite, com sua linguagem onírica, permeada de ambiguidades e incertezas, e seus caminhos tortuosos. Como Joyce dizia: "É natural que as coisas não sejam tão claras à noite, não é?" (CAMPOS, 2001, p. 196). Como uma consequência inevitável, classificar o Wake em um gênero literário mostra-se um desafio - ou, talvez, um esforço dispensável, que nada acrescentaria à compreensão da obra. Haroldo de Campos lança possibilidades criativas de referência classificatória com os termos "prosapoesia" (CAMPOS, 2001, p. 29) e "romance-rio" (Id., p. 27), também usado por Donaldo Schüler: "Por flores e por floras, por faunos e por faunas, por vidas e por vias, flui Finnegans wake, o romance e o rio, o romancerio" (SCHÜLER, 2004, p. 15). (É curioso notar uma outra possibilidade de grafia para esse último termo inventado, considerando que a opção pela duplicação da letra " $r$ " poderia remeter mais imediatamente à bela palavra que abre o fragmento número 1 de Finnegans wake, optando por, como Joyce fazia quase sempre, dispensar o uso de hifens - riverrun, ou riocorrente, na tradução feita por Augusto de Campos, e rolarriuanna, na de Schüler.)

Respostas a essa problemática são dadas no próprio texto de James Joyce - e devem ser entendidas sempre nesse mesmo lugar. Uma possível afirmação concisa a respeito de tantos questionamentos, entre eles o de gênero, o de literatura e o de cânone, está em uma frase relativamente curta: "this is nat language at any sinse of the world" $(\mathrm{FW}, 83.12)^{16}$. Joyce condensou aí tanto a afirmação de que "isto" não é linguagem em nenhum sentido do termo, quanto a de que não é linguagem em parte nenhuma do mundo, e ainda de que $\underline{e}$

16 "Isso é linguagem-noite em qualquer sentido do univerbo." 
linguagem noturna, com "nat" lembrando "noite", night (inglês), nacht (alemão); "world", entre palavra e mundo, foi genialmente traduzido por Donaldo Schüler como "univerbo". Confirma-se, assim, tanto o estatuto noturno, que acompanha uma incerteza da escuridão - vemos significantes como vemos silhuetas e sombras, que nos situam gerando incerteza - , quanto a temporalidade da noite que se resvala em madrugada indefinida, que é a vastidão do breu, em que tanto espaço quanto tempo são dotados dessa qualidade vasta e ao mesmo tempo fosca; confirma-se, ainda, a linguagem que não é a linguagem que se espera em nenhum sentido do univerbo: o próprio livro se afirma como uma suposta nãolinguagem que é simplesmente uma linguagem de caráter próprio, afirmado como algo noturno que se contamina e se faz pelas possibilidades de labirintos oníricos.

De forma geral, esse desprezo do cânone ou espécie de pouco caso com Finnegans wake é carregado de conclusões precipitadas e, diga-se, desistências rápidas. Os leitores minguam como se o texto não merecesse atenção, não merecesse leitura. Hipóteses de que seja uma grande piada ainda se mantêm. Como afirmaram, em 1944, os pioneiros Joseph Campbell e Henry Morton Robinson, quando Finnegans wake foi publicado integralmente, isto é, cinco anos antes:

\footnotetext{
'What does it all mean?' 'Why should we bother about a book so hard to read?' were questions quite generally asked. Even normally responsive readers dismissed the book as a perverse triumph of the unintelligible. ${ }^{17}$ (CAMPBELL; ROBINSON, 2005, p. xxi)
}

No entanto, ainda que somente mais de vinte anos depois, o estudioso norteamericano, também pioneiro na incursão profunda ao Finnegans wake, William York Tindall, afirma: "Everything in the Wake has meaning, definite, limited by a frame or immediate context, and discoverable. Our danger (...) Is too much

17 “'O que isso tudo significa?' 'Por que deveríamos nos ocupar com um livro tão difícil de ser lido?' eram perguntas feitas frequentemente. Até mesmo os leitores normalmente interessados desprezaram o livro como um triunfo perverso do ininteligível" (CAMPBELL; ROBINSON, 2005, p. xxi) 
ingenuity"18 (TINDALL, 1969, p. 22). James Joyce engendra uma obra calcada em racionalidade e enquadramento meticuloso de cada detalhe em uma estrutura com criatividade ininterrupta, e esse controle é visível ainda que resulte em uma obra inclassificável e ainda que o resultado gere comentários que a relacionem ao completo caos e a uma ideia de puro nonsense. O que Tindall aponta como o risco maior não é, note-se, que o leitor talvez não entenda o livro, ou não veja alguma referência, mas sim que seja ingênuo diante da existência de possibilidades no texto e o tome por puro fingimento de quebra-cabeça.

As dificuldades são evidentes, o susto ou a antipatia causada pelo Wake ultrapassou o passar dos anos. Mesmo os leitores mais próximos de entendê-lo tiveram suas dificuldades, resistências e uma infinidade de críticas diante dele. Como ler, então, hoje, uma obra como Finnegans wake? Está aí para ser lida ou para ser rejeitada, tida como uma piada para manter críticos ocupados ou como exemplo do funcionamento da linguagem em uma mente esquizoide? Exige-nos uma postura diferenciada? Está dentro ou fora da literatura - ou é na verdade sua ameaça?

Há, talvez, um grande conjunto de duas maneiras, grosso modo, de se encarar o texto literário, ou uma obra de arte qualquer: primeiro, sentindo que conseguimos extrair uma finalização de nossa leitura ou, ao contrário, na segunda maneira, sentimo-nos grave e verdadeiramente impotentes ao sequer cogitar essa possibilidade. De forma geral, haveria, assim, uma bifurcação de duas distintas e abrangentes escolas ou caminhos, sendo aquela que dá uma interpretação fixa, considerada correta ou superior, a vertente mais obsoleta. Os perigos da segunda, no entanto, são também apontados com frequência: não se pode dizer tudo e qualquer coisa!, dizem. O receio de uma espécie de perigosa autotelia que desestabiliza o mais tradicional corpus hermenêutico se instala entre as duas extremidades bifurcadas, pontas de diferentes abordagens que não somente lidam com o texto de maneiras antagônicas, mas ainda, e por isso mesmo, partem de noções igualmente opostas da própria ontologia de uma obra

\footnotetext{
18 Tradução livre do trecho de Tindall: "Tudo no Wake tem um significado definido, limitado por uma moldura ou contexto imediato, e passível de ser descoberto. Nosso risco é o excesso de ingenuidade."
} 
de arte. Sendo a primeira vertente bastante autoexplicativa, esgotando-se facilmente qualquer tentativa de discorrer sobre ela, poderíamos abordar direto o problema indicado na segunda, de que tudo poderia ser dito na abertura absoluta e desgovernada que descentraliza as interpretações da obra em uma descentralização e horizontalidade total (e vejamos se é isso mesmo o que ocorre), considerando, no caso, o texto literário, e especificamente o Wake, aquele que poderia ser acusado de ser um dos textos mais anárquicos e ameaçadores do século XX.

Em primeiro lugar, dir-se-ia que o texto não se termina.

O texto que não se termina significa tanto um texto que não acaba quanto um texto que nós não terminamos de ler e, ainda, um texto que não finalizamos, sendo impossível dar-lhe qualquer ultimato interpretativo. Isso não se reduz a um caráter interminável condicionado pela leitura única que cada leitor, com seu aparato psicológico e experiência que lhe são inerentes, executa ao se deparar com o texto. Tampouco diz respeito somente a uma série de releituras feitas em diferentes momentos históricos, de modo que Machado de Assis tenha sido reinterpretado com o passar do tempo etc. A infinitude de que se trata aqui não se refere a esse tipo de desdobramento, ainda que não os anule nem os negue como processos naturais da presença do texto em diferentes épocas e sob diferentes olhos.

Se não é, então, um desses fatores externos o que insere o texto no tempo da infinitude, poderíamos inferir que seja, assim, alguma característica interna. No entanto, faltam-nos dados - ou, pior, evidências - de que seja possível a separação, como se faria, digamos, entre textos primários e secundários, ou qualquer procedimento semelhante. Só que isso potencialmente nos colocaria sob o constrangimento de admitir que não há obras de arte, pois elas estariam por toda a parte; potencialmente, tudo conteria a infinitude. Tudo seria arte: como lidar com essa possibilidade que parece destruir as fronteiras de definição entre aquilo que é e o que não é um objeto de apreciação ou de estudo? 
Desfaçamos alguns passos. Se não considerarmos o texto em sua projeção ao infinito, isto é, se admitirmos então que ele desemboca em uma interpretação e, assim, detém, atinente, uma exegese fechada, somos obrigados a explorá-lo em busca de sua verdade. Cada leitura investigativa seria como um caminho para fora da caverna platônica; estaríamos cada vez mais próximos das ideias. Da mesma maneira que o caminho de acesso à epistéme não rejeita 0 mundo do familiar e da dóxa, mas, em verdade, confronta-se com as sombras para nelas alcançar a luz, o contato com o texto de uma maneira insistente e atenta desvelaria, eventualmente, sua verdade, a despeito de qualquer aparato teórico-crítico com que qualquer leitor pudesse contar nessa varredura. Nesse sentido, uma experiência com o texto seria suficiente.

Sabemos, no entanto, que interpretações unas não nascem assim. De forma geral, vêm de fora para dentro, de cima para baixo, de maneira imposta e consagrada por convenções ou argumentos de autoridade. A experiência com o texto traz à tona, em geral, alguns poucos consensos, uma dose de subjetividade e, havendo consonância teórico-critica, eventuais conclusões convergentes quanto aos aspectos mais superficiais do texto, em especial aqueles relacionados às categorias mais estanques da forma. Ainda assim, nem sempre há consenso mesmo nesse campo. Gêneros textuais podem parecer categorias fortemente imiscíveis, mas frequentemente não são facilmente definidas.

Finnegans wake é justamente uma obra cujo gênero jamais foi definido ou (in)definido como sui generis - , que sequer traz consigo rótulo evidente de prosa ou de poesia. Augusto de Campos expressa esse dilema de maneira sintética com os neologismos "prosoema", "romance-rio", "romancepoema". Esse nó se alastra: considerando que Wake não se encaixa em um gênero, uma série de assunções a seu respeito não pode ser feita tão facilmente e possivelmente caem por terra. A fuga de um conceito fechado, assim, em efeito dominó, acaba por impossibilitar uma série de inferências que dele naturalmente decorreriam, assim como o contrário também se dá com a fixação de uma categoria que consequentemente baliza tantas outras de imediato, seja a respeito da extensão, da forma, da qualidade, das potencialidades sonoras e semânticas etc. Se um texto é composto de versos, é certamente um poema, 
tem estrofes, possivelmente um esquema de rimas controlado; se for um soneto, temos ainda mais inferências prontas para serem testadas, inclusive a respeito do conteúdo; se é conto, é menor do que se for romance e assim por diante.

Um texto inclassificável se apresenta, dessa maneira, já de partida como um problema em si, uma fonte de inquietação interminável, ou que não cessa tão rapidamente. Matéria para manter críticos ocupados por anos, como profetizou o próprio Joyce. Corre o risco, certamente, de ser condenado para fora da literatura - por não caber nela, não ser contemplado em suas barreiras. Se o esquema existente não o contém, comumente se supõe a existência de defeito no texto, não uma possível limitação das categorias que se consolidaram para sua interpretação. O conservadorismo expulsa o que ameaça a tradição por preferir deixar de lado uma obra a implodir um sistema que abarca tantas outras com segurança e conforto. É instaurada uma problemática mesmo a partir do ponto de confronto que é uma leitura, na medida em que o leitor se espanta diante do texto literário, como discorre Piero Eyben em Escritura do retorno:

\footnotetext{
Antes, o texto joyceano torna-se, pela falta, repulsivo, em sua intransitividade. Não há leitor que se veja nele identificado, como completude. Sua estrutura inacabada faz da verdade identitária uma falácia. De modo que, o desvio, o revés de sua leitura, nos leva a uma significância zerológica, na qual todo sujeito se anula e torna-se apenas membro da obra que este interpreta, como significantes. (...) A linguagem do inacabamento seria uma linguagem da falta, pois coloca no caput o sem-cabeça. (EYBEN, 2012, p. 610)
}

Rejeita-se o texto por saber que lhe impor uma interpretação qualquer seria gritantemente descabido. Uma leitura de Finnegans wake que busque e defina sua trama, por exemplo, encaixando no tempo, no espaço, nos personagens (protagonistas, antagonistas), nos narradores e em todas as categorias da narrativa uma série de respostas imutáveis, necessariamente berraria sua artificialidade. Para que se leia o texto como é, sem distorcê-lo com planificações, simplificações e cerceamentos, deve-se despi-lo das forças que o comprimem. Somente assim se pode ler o texto como ele se apresenta, 
respeitando sua integridade. Deve-se, então, ir à leitura esperando nada menos que o infinito.

Lembramos aqui o que diz Jacques Derrida em "Duas palavras por Joyce”:

É com este sentimento, poderia dizer com este ressentimento, que devo estar lendo Joyce há muito tempo. (...) Mas não sei se podemos dizer "eu leio Joyce", como acabei de fazer. Naturalmente, só podemos ler Joyce, quer saibamos disto ou não. É a sua força. Mas os enunciados do tipo "leio Joyce", "leiam Joyce", "você já leu Joyce?" sempre me pareceram cômicos, irresistivelmente. (DERRIDA, 1992, p. 21)

Nessa mesma palestra de 1982, Derrida também faz uma "simplificação descabida" em duas grandezas. Refere-se às maneiras de o autor deixar-se nos arquivos de sua obra, apagando-se quanto mais ela se faça presente. Apesar de ter sido proposto aqui o exame da outra ponta dessa relação - a do leitor - a primeira atitude de autor descrita por Derrida pode ser vista como análoga à maneira de leitura que expusemos, ligada a certezas e fincada em uma ideia de verdade textual: consiste naquele que "escreve para dar", de maneira que a obra se dê a ponto de poder ser valorada, "gostável", "amável" (Ibid., pp. 19-20) e, diríamos ainda, acessível e possível. A segunda atitude, que Jacques Derrida considera semelhante à de Joyce, é a de hipermnésia: em vez de acessarmos uma materialidade pura de texto no esquecimento do autor, vivemos em função de sua memória, em meio a sua presença.

Se o texto se nos apresenta dessa maneira, precisamos estar dispostos a entender que ele nos escapa. Fugidio, se transforma em espectro. Sair da caverna não é ir além dela, nem deixá-la para trás no percurso; o caminho platônico é um modo de estar que adentra mais, como o movimento que pretende mergulhar no texto literário: não se trata de ultrapassá-lo, mas de estar cada vez mais inteiramente nele. Nesse sentido, confessa-nos Derrida: "Sim, a cada vez que escrevo, e mesmo nas coisas da academia, um fantasma de Joyce está presente em minha abordagem" (Ibid., p. 23). O entendimento de Jacques Derrida de um caráter espectral que ronde o texto através da escritura é profícuo 
em uma série de análises; aqui, podemos ensaiar aproximá-lo de uma ideia de temporalidade que pode ser retirada do próprio Finnegans wake.

\section{Fluidez vida-morte}

A mitologia egípcia está presente em quase todos os capítulos de Finnegans wake, às vezes escondida entre nomes que assinalam múltiplas assinaturas - desfazendo, portanto, a própria ideia de nome -- e engendrando numerosas rasgaduras temporais. No capítulo 4 do livro I, o "livro dos pais", denominado por Campbell e Robinson "His demise and resurrection", o desmantelamento dos nomes é especialmente profícuo. Em meio a isso, segundo Donaldo Schüler, "O tempo cronológico se anula em favor de um tempo não medido por aparelhos, tempo feito só de fluxos (...) Em julgamento está nossa cultura, nossas certezas, nosso vocabulário, nossa maneira de dizer e de narrar" (2003, p. 169). HCE é preso e logo o rio Nilo é evocado, aproximando-o de Osíris; logo torna-se personagem morto, "once and for all out of plotty existence" (FW, 76.18), fora da "existência narrada", como aponta Schüler. Podemos apontar aí uma espécie de resumo de toda a literariedade de Finnegans wake: HCE é capturado e morre, de certa forma, para sempre, se morrer significa estar fora de uma certa narrativa; não estará ausente, porém, por toda a eternidade. O lugar onde jaz é construído por um arquiteto com nome de cemitério parisiense, Peurelachasse (Père Lachaise), que condensa la peur (medo, em francês) e la chasse (a caça), pois não é um não-lugar dos mortos; ao contrário, a morte aqui é acontecimento que desemboca em dilúvio que retoma a força vital. O que seria um par de oposição se (con)funde e tem sua ambivalência transformada (ou transtornada): vida e morte, dia e noite, pai/mãe e filho(a)(s), os irmãos Shem e Shaun (ao contrário de oposições rígidas como Caim e Abel, Rômulo e Remo).

Como dissemos, o capítulo é rico em temporalidade despedaçada: o tempo é indicado de maneira antirrepresentativa, sem que se possa calcular ou mapear um momento a partir de suas referências: "Best. This wastohavebeen 
underground heaven" (FW, 76.33) ${ }^{19}$ Diferentes tempos verbais intercalados não somente plantam uma dúvida, mas efetivamente explicitam a impossibilidade de definição, a fluidez entre os períodos. A morte - especialmente aquela que será seguida de ressureição - perambula por presente, passado e futuro. "But abide Zeit's sumonserving, rise afterfall" (FW, 78.7) ${ }^{20}$. Nesse excerto, o tempo parece ser espécie de entidade burocrática que controla o universo de Finnegans wake, garantindo que um ciclo seja cumprido. A morte de Humphrey Chimpden Earwicker, bem como todos os seus corolários, não são controláveis por seres que controlem seu tempo e a sucessão de acontecimentos de suas vidas; o ciclo - como nas disposições de Giambattista Vico - é inelutável e força sua continuidade a despeito das vontades. Elucubrações não mudam as necessidades do Zeit. A fluidez é como a correnteza do rio, que não escolhe seu direcionamento.

Se, frente ao texto, um período sequer puder ser lido de apenas duas maneiras diferentes, já teríamos aí dois textos inteiros também completamente distintos. A semântica não pode se encerrar a cada frase, nem a cada termo, nem a cada trecho ou capítulo ou seja o que for; lemos o todo, considerando que todos os trechos estejam incessantemente interligados e interdependentes, de maneira que a totalidade do texto seja um organismo indissolúvel. Quais as chances, assim, de que um texto qualquer seja absolutamente rígido, com significados puramente literais que alcançam seus alvos pontualmente, sem nenhuma borda nem fenda de significação, seja ele concebido como texto literário desde o berço ou não?

Em vez de concluir que há certos textos que, rebeldes, fogem das rédeas do sistema literário e suas classificações determinantes, tendemos muito mais a enxergar que todo texto tem uma faísca disseminativa dentro de si que frequentemente é ignorada em leituras que o planificam em uma sequência palpável para as classificações às quais estamos acostumados, que nos aparecem como urgências quando, na verdade, a urgência é o próprio texto. Ele demanda nossa leitura; urge que nos deparemos com os textos como são e que

19 "Bem. Este subterrâneo foi-para-haver-de-ser-céu (...)".

20 "Mas aguardemos o requerimento do tempo, despertar após-queda." 
rejeitemos distorções que parecem visões translúcidas e, por isso, nos mantêm confortáveis. O que o texto faz é nos tirar do conforto de nossa língua e nos lançar a uma outra, própria dele mesmo; se nos lançamos à leitura sem buscar categorias estanques, podemos finalmente conseguir sair do que julgamos concreto em direção ao que nos vem de espectral, prismático - aquilo que não pode existir num tempo que não seja o do porvir. Qualquer presentificação estanque negaria essa situação de promessa do futuro, promessa que permanece, messianismo sem previsão, pois, caso se concretize, o porvir se desmantela no cumprimento da promessa, que é seu desaparecimento.

Apaga-se por inteiro o suposto perigo de que, no infinito, qualquer coisa que nada tem a ver com o texto possa ser dita ou acusação da leviandade de que assim, tudo seja arte, indiscriminadamente, receios frágeis e superficiais que nos limitam a concepções específicas de arte e nos afastam normativamente de leituras que sejam um modo de estar no texto $-e$, portanto, efetivamente 0 contrário de sair dele ou de excedê-lo. O problema, na verdade, reside em subestimar as possibilidades de um texto muito mais do que em superestimar qualquer rastro ou sombra do espectro escritural, esvaindo-se aí a própria essência do texto em troca de uma carapuça que o defina.

Um porvir desfigurado e desfigurante faz do texto uma matéria de instabilidade nas mãos do leitor. O caráter fantasmagórico latente povoa a escrita de escritura. O caráter espaço-temporal do Wake nos leva para o caminho do intertexto, do subtexto, de tudo que está contido e condensado no único texto que chamamos de Finnegans wake. O que desmantela as certezas está anunciado desde o título: há um velório, um luto e um tempo da eternidade da morte, mas há o movimento de despertar, acordar, o reinício; o ciclo se faz novamente no sim que responde pela continuação eterna, não pela finalização. Desde o título, portanto, temos a postura de leitura definida: ler e reler Finnegans wake, sem cronograma, sob o espectro de Joyce e da babelização das línguas sem delimitação espaço-temporal.

O espectro tem relação, ainda, com o que não se materializa e, por isso, não pode ser visto com clareza. Entre tantos temas e motivos recorrentes, 
recirculando por todo o Finnegans wake, a visão é um dos sentidos amplamente explorados como tema e fonte de trocadilhos. A elaboração altamente perfeccionista do aspecto fonético de Wake é atribuída também à apuração da audição, inevitável consequência da cegueira causada pelo glaucoma, e nos faz recordar a recomendação de Joyce, de que se lessem os fragmentos em voz alta, para uma experiência outra de leitura (ou para a experiência). A gravação da récita feita pelo próprio autor do episódio "Anna Livia Plurabelle", ou "ALP", como ele chamava, é uma relíquia, de grandioso valor para estudiosos de sua exímia obra. Em texto composto por tantos neologismos e em meio à simultaneidade de idiomas de diversos troncos linguísticos, há diversos caminhos e múltiplas escolhas para a entonação, o ritmo e a pronúncia do texto de Finnegans wake, e essas são decisões que devem ser feitas pelo leitor capaz de vislumbrar a polissemia de cada sintagma por meio da leitura em voz alta.

A necessidade de envolvimento do leitor, ouvinte, instrumentista ou espectador na arte caracterizada como moderna é sempre decorrente de uma autonomia que lhe é conferida propositalmente ou não, em certa medida, frente à obra, que se mostra maleável e porosa a esse envolvimento. $O$ fato de que Finnegans wake é uma obra que deliberadamente proporciona autonomia ao leitor transparece em sua estrutura, inclusive se considerarmos a decisão primeira de por onde começar, pois o livro pode ser acessado a partir de qualquer um de seus fragmentos, a despeito da numeração neles embutida. Esta facilita, certamente, a citação, o compartilhamento etc., mas a ordem de leitura é lançada ao leitor - um engendramento c'est à vous de sobreposição de estados não comunicáveis, de simultaneidade de possibilidades, no engendrar de um multiverso em detrimento de um universo.

Em Obra aberta, o teórico italiano Umberto Eco estabelece fronteiras fundamentais entre obras tradicionais e obras modernas, referindo-se propriamente a suas formas e concepções, fugindo de definições de cunho meramente histórico-diacrônico. O ponto de partida basilar para essa divisão é o fator da ambiguidade como ausente, no caso das obras clássicas ou moldadas tradicionalmente, ou presente, no caso das obras de arte modernas. Citando Finnegans wake, obra última de James Joyce, como paradigma de obra moderna 
caracterizada como aberta segundo seus preceitos, isso fica mais claro se for colocada a seguinte pergunta, relativamente simples: de que trata o referido livro, ou, dir-se-ia, "sobre o que" é Finnegans wake?

No caso de obras já há muito tempo consideradas clássicas, a resposta pontual a essa pergunta é possível, ao menos segundo Umberto Eco, sem acarretar muitos questionamentos estruturais. No caso de uma opera aperta como Finnegans wake, no entanto, a resposta pontual é impossível - ou melhor, é possível, porém sempre parcial e funcionando como gatilho para outros pontosproblema que devem ser alinhados com a resposta escolhida. Podemos ensaiar possibilidades sobre o Wake afirmando, por exemplo, que o livro trata de luto, ou que é sobre julgamento, ou sobre uma família dublinense, ou a respeito de sonho e inconsciente, ou que é um sonho do protagonista; há diversas respostas e nenhuma parece vir como satisfatória. Cada uma delas deve implicar uma série de definições estruturais - se a narrativa é um sonho, deve haver alguém que sonha; se é o (possível) protagonista HCE quem sonha, temos, então, um foco narrativo definido. Estabelecer, porém, um foco narrativo cuja fonte se estabelece no plano mental inconsciente tem implicações outras a respeito de como defini-lo em seu estatuto de narrador e de personagem. Assim, é necessário atentar-se ao fato de que cada afirmação acarreta uma série de outras consequências.

A indefinição de elementos estruturantes da narrativa, no entanto, não é válida somente para uma obra extrema como Finnegans wake, mas para qualquer obra que se aplique ao paradigma estabelecido por Umberto Eco. Ademais, destaca-se o papel do leitor na projeção semântica da obra, não do ponto de vista do senso comum de que a subjetividade confere certo empirismo interpretativo, aberto a uma relatividade sem horizonte definido, mas em sentido um tanto mais fleumático de que a manipulação do objeto interfere no resultado do mesmo - quase como um experimento de Erwin Schrödinger. São, por conseguinte, cabíveis as analogias com o Livre de Stéphane Mallarmé, (poe)móbiles, a música aleatória de Luciano Berio (que produziu música inspirada no livro Chamber music, ou Música de câmara, de Joyce) e de Karlheinz Stockhausen. A diferença do envolvimento necessário do público 
apareceria para Eco, portanto, em um grau consideravelmente maior na obra de arte moderna.

Lembrando o que diz Samuel Beckett sobre o texto de Joyce, o que podemos destacar a respeito da maneira como se apresentaria um acontecimento ao leitor em Finnegans wake é que isso, na verdade, simplesmente não ocorre, ou ao menos não em termos de uma cena contada, narrada como conhecemos. A narrativa como a conhecemos, em que uma cena é mostrada, contada ao leitor, é substituída aqui pela própria experiência da cena ou da coisa que seria descrita. Ao invés de contar uma cena, dá-se a mesma ao leitor. Não se trata apenas de se desapegar do tipo de descrição realista, objetiva, que presume distanciamento, pois também não se trata do relato em primeira pessoa, subjetivo e, por isso, dúbio, na tentativa de explorar a psique de uma personagem específica em suas contradições internas, tentando acessar a complexidade de sua consciência. Nenhuma dessas abordagens opostas seria possível no Wake, pois nele nem sempre se pode diferenciar as vozes do texto - e nem sempre é preciso, uma vez que não há enredo que dependa desse acompanhamento.

4. Paralelos: psicanálise, teoria da relatividade, música

A disposição estrutural de Finnegans wake em circularidade é o que permite o acesso a partir de qualquer página e o leitor, por sua vez, tem autonomia explicitamente garantida, impelido a tomar uma decisão no primeiro acesso ao livro. A circularidade, no entanto, e a numeração dos fragmentos sugerem uma ordem tácita - que não pode ser simplesmente ignorada, mas não deve ser vista, também, como a única forma de leitura; assim se engendra o nível de ambiguidade da obra. Como em Ulysses a presença da Odisseia na concepção de cada um dos capítulos é uma possível referência de leitura, mas não a linha central, isto é, não é um necessário paralelismo à incursão ao livro de Joyce. Ler literatura é dispor-se a um caminho que não busca certezas, ao contrário do que o apego a análises literárias demasiado pragmáticas, ainda que 
o neguem, possa sugerir. Mesmo em um livro de cunho bastante tradicionalista, como A Análise literária de Massaud Moisés, o lembrete é claro:

\begin{abstract}
A leitura com profundidade pressupõe sempre que o texto literário, sendo composto de metáforas, é ambíguo por natureza, ou seja, guarda uma multiplicidade de sentidos. Ler mal significa não perceber a extensão dessa ambiguidade, ou apenas percebê-la sem poder compreendê-la ou justificá-la. (MOISÉS, 1969, p. 24)
\end{abstract}

Exigir uma explicação para cada nó morfológico ou sintático que se vislumbra no texto ou acusa-lo de impor dificuldades ao acompanhamento do enredo são acusações a Finnegans wake que partem de uma concepção possivelmente questionável de literatura e/ou lidam com uma ideia redutora e limitante de exegese, ignorando a alta voltagem do cociente conotativo que o texto oferece e a riqueza de leituras e possibilidades - que estão longe de formar um todo incoerente ou um texto composto de nonsense; ao contrário, Finnegans wake foi concebido de forma comprovadamente calculada e o humor do texto está distante de ser tão hermético quanto se pensa. Campbell e Robinson utilizam um galicismo bastante peculiar para caracterizar Finnegans wake: cauchemar. Derivado de cauquemaire, termo registrado a partir do século $\mathrm{XV}$, pode definir, simplesmente, uma espécie de sonho incômodo, no limiar do que seria um pesadelo. No dicionário Larousse ${ }^{21}$, é precisamente uma "manifestação onírica que pode causar uma forte resposta emocional negativa na mente, de medo ou de horror". Sua formação se deu a partir do termo picardo cauchier, que significa "pressionar" ou "empurrar", e do termo germânico proveniente do holandês mare, que significa "espectro", "fantasma". O campo semântico em que se enquadra o termo envolve da angústia ao desespero. $O$ leitor, portanto, estará avisado: não se trata de um sonho planificado e agradável, mas de um percurso sinuoso, de que se deve duvidar e ao qual nos entregamos sem reservas. O leitor deve se dispor ao obscuro em vez de exigir clareza, como em um sonho caracterizado por Freud, em que objetos são símbolos e o que

21 Larousse 2013. "Cauchemar: nom masculin. Rêve pénible avec sensation d'oppression, d'angoisse. Idée, chose ou personne qui importune ou cause du tourment : Ce professeur est mon cauchemar. Synonymes : Hantise, obsession, tourment." 
aparenta ser apenas um fato que se explica por si pode não sê-lo. A isso se acrescenta o que diz Freud sobre o reflexo (como ato involuntário, automático, não uma decisão consciente) da negação e a pulsão de destruição: "O texto [da negativa] pode negar-se à interpretação como meio de reagir às palavras de um outro significante, da própria enunciação" (EYBEN, 2012, p. 283). A negação, que vem do estranhamento, produz afirmação; só se enxerga em Finnegans wake o estranho a partir de noções como narrativa e tempo linear, negando-se o estabelecido em direção a uma (nova) resposta.

A referência a Sigmund Freud não vem apenas dos dados biográficos, em afirmações do próprio autor de que o livro é configurado como um sonho. Joyce dizia não ser nada simpatizante da psicanálise. Apesar disso, Lucia, sua filha, tinha distúrbios mentais que ficaram mais graves com o passar do tempo e chegou a se consultar com Carl Jung, colega de Freud nos primeiros estudos psicanalíticos, com quem ela se deu inicialmente muito bem. Em Finnegans wake, Joyce cita tanto Freud quanto Jung, maiores referências no nascimento da psicanálise, um tanto sardonicamente. No fragmento 115, como destaca Lenita Esteves em sua tese, lê-se: "old Sykos who have done our unsmiling bit on 'alices, when they were yung and easily freudened" (FW, 115.21-23). Como muito do que aparece no Wake (e muito do que aparece em nossos sonhos), a citação não é clara e direta, estando escondida, porém possível de ser encontrada ("yung and freudened"), com o termo "sykos on 'alices", separado em duas partes, como uma "cadeia truncada" (ESTEVES, 1999, p. 86), formando "psychoanalysis", e a referência à Alice de Lewis Carroll - autor cuja obra sabemos ter influenciado Joyce e que aparece no trecho aqui referido como "old syko" ("old psycho", um "velho louco"). O poeta e crítico dinamarquês Kristensen certa vez perguntou se Joyce acreditava na Ciência nova de Giambattista Vico, ao receber a sugestão de Joyce que a lesse para ler Finnegans wake. Joyce respondeu: "Não creio em nenhuma ciência, mas minha imaginação cresce quando leio Vico, como não aconteceu quando li Freud ou Jung" (ELLMANN, 1989, p. 853).

Carl Jung chegou a ler Joyce e também não abrira caminhos para uma simpatia maior entre eles: "Jung garantiu que algumas de suas palavras 
"portmanteau" e neologismos eram notáveis, mas disse que eram acasos; ela [Lucia] e seu pai, comentaria ele mais tarde, eram como duas pessoas descendo ao fundo de um rio, uma caindo, outra mergulhando" (Ibid., p. 837). A metáfora do rio para a linguagem esquizofrênica, pelo menos, certamente teria agradado Joyce se não viesse nessa ocasião. Especialmente vindo de alguém que havia percebido em sua produção literária (e na de Lucia, ao ler alguns de seus poemas e apontar que havia ali indicações de problemas mentais) uma exemplificação de insanidade.

Uma possível analogia entre uma obra como Finnegans wake e a Interpretação de Muitos Mundos (IMM), formulação de estados relativos elaborada pelo físico quântico Hugh Everett, encontra-se no esteio da afirmação de Umberto Eco a respeito dessa mesma obra, fazendo um paralelo entre a relatividade de Einstein e as possibilidades diversas de tempos e espaços distintos e simultâneos na obra de Joyce:

Em Finnegans wake, encontramo-nos enfim, verdadeiramente, na presença de um cosmo einsteiniano, curvado sobre si mesmo - a palavra inicial une-se à palavra final - e portanto acabado, mas por isso mesmo ilimitado. Todo acontecimento, toda palavra, encontra-se numa relação possível com todos os outros e é da escolha semântica efetuada em presença de um termo que depende o modo de entender todos os demais. Isso não significa que a obra não tenha um sentido: se Joyce introduz nela certas chaves é justamente por desejar que a obra seja lida num sentido determinado. Mas esse "sentido" tem a riqueza do cosmo, e o autor quer, ambiciosamente, que ele implique a totalidade do espaço e do tempo - dos espaços e dos tempos possíveis. $O$ instrumento-mor dessa ambiguidade integral é o pun, o calembour. (ECO, 1989 p. 48)

Já no início de seu livro, ao citar a obra de James Joyce como "exemplo máximo de obra 'aberta'” (Ibid., p. 47), Umberto Eco traça uma referência com Albert Einstein, por meio de Edmund Wilson, a respeito também da obra anterior, Ulysses:

Sua força, ao invés de acompanhar uma linha, expande-se a si mesma em todas as dimensões, (inclusive a do Tempo) (...) Joyce desenvolveu considerável maestria técnica para apresentar-nos os elementos de sua históra numa ordem tal que nos torne capazes de encontrar sozinhos os nossos caminhos. (Ibid., p. 48) 
Como sabemos, a dita circularidade do Wake é construída de tal forma que dá margem a diferentes formas de acesso e leitura. Isso gera diversas possibilidades paralelas e igualmente aceitáveis dentro da estrutura, se entendermos que, de fato, qualquer página pode ser a primeira e qualquer página pode ser a última. Essas possibilidades diferem não apenas em suas características, mas também em suas implicações. Assim, coexistem paralelamente essas possibilidades, a partir das ordens de leitura efetivamente disponíveis, e a obra permanece una. Até mesmo dentro de um capítulo pode ser que pouco importe a ordem de onde se começa a ler. De um parágrafo para outro, o assunto pode mudar drasticamente. Tomemos como exemplo o capítulo III do terceiro livro, em que a primeira página fala dos Four Old Men, a segunda inicia uma ode a Isobel, a filha, discorrendo sobre toda a sua beleza e ingenuidade, e o parágrafo seguinte salta nada menos para Humphrey Chimpden Earwicker bêbado no chão de seu pub.

Em artigo intitulado "The Finnecies of music wed poetry: A música e 0 Finnegans Wake", Caetano Galindo, tradutor da mais recente versão em português de Ulysses (2012) e da única de Finn's hotel (2014), parte da ideia desenvolvida por Walter Pater de que "Toda a arte constantemente aspira à condição da música" (PATER apud GALINDO, 2010, p. 286; tradução do trecho feita por Caetano Galindo). Frequentemente se afirma, percorrendo a fortuna crítica de Finnegans wake, que essa obra é o resultado de suposto projeto formalista de extrema acuidade, em que a semântica é absolutamente preterida em relação à forma, à estética focada na materialidade do significante. No entanto, não há possibilidade de falar de significante sem significado, sendo esse um par indissolúvel, e acusar Joyce de se apoiar na pura materialidade do signo para construir um texto de conteúdo calcado no nonsense e, portanto, "incompreensível" - ou, mais especificamente, um texto que efetivamente nada tenha a dizer - e puramente sonoro se mostra descabida a qualquer leitor atento do Wake.

A aproximação entre a literatura joyciana e a arte musical é, contudo, bastante profícua. Além de a sonoridade, como dissemos, ser aspecto de suma importância nos textos de Joyce segundo ele próprio, essa proeminência é 
explícita na leitura, observando-se os jogos linguísticos rítmicos e o papel do aspecto fonético na compreensão de muitos dos trocadilhos (puns). Ainda que os fatores biográficos nada determinem a respeito da produção literária, cabe apontar também, a título de curiosidade, para a relação estreita de Joyce com a música: queria ser cantor e sua mãe foi cantora e integrou coros de igrejas. A aproximação entre experiências literárias e música não seria algo novo para o autor irlandês, que demonstrava esse interesse desde os poemas de Chamber Music - admirados por Ezra Pound - , passando por trechos eminentemente melódicos de $A$ Portrait of the artist as a young man, até o episódio das Sereias (como é conhecido) de Ulysses.

Richard Ellmann afirma que, diante de algumas das críticas frequentes a respeito do caráter literário de Finnegans wake, "o aspecto musical do livro era uma de suas justificativas" (ELLMANN, 1989, p. 865). Questionado por Terence White Gervais "se o livro era uma mistura de música e literatura", "Joyce respondeu laconicamente: 'Não, é pura música.' (Id.). A variedade de formas de entonação e pronúncia aproximam o Finnegans wake do que seria uma composição musical que precisa ser executada, lida como se lê a partirura em música - conferindo vida às indicações que o papel traz. O leitor se vê, dessa forma, no exato centro dessa demanda, sendo-lhe exigidas seguidas decisões persecutórias. Nem Ulysses, nem Finnegans wake são obras para serem lidas de forma passiva, apenas acompanhando a narrativa que se desenha sozinha, recostando-se, acomodando-se em leitura plácida; é preciso lê-los de maneira executiva.

O capítulo 11 (considerado, na divisão de Campbell e Robinson, o capítulo 3 do livro II - que chamam de "livro dos filhos" - denominado "Tavernry in feast") reúne sensações diversas, com destaque ao sentido da audição, em cenas de festejo e bebedeira no pub da família dublinense. As cenas (ou sensações) se assemelham ao que seria um sonho de HCE, tendo, contudo, também a sua participação. Na nota preliminar de Donaldo Schüler, "A identificação chega a extremos. HCE sonha e é sonhado. (...) Recolhem-se fragmentos espalhados no tempo e no espaço" (2003, p. 215). Em meio a 
transformações de HCE em Rá, deus egípcio do Sol, histórias ouvidas pelo rádio que envolvem visitas de um norueguês a Dublin em busca de um alfaiate, casamento, quedas e um sétimo trovão, faz-se musicalidade no ambiente barulhento.

Snip snap snoody. Noo err historyend goody. Of a lil trip trap and a big treesnooker (...) (FW, 332.1-2) 22

For hanigen with hunugen still haunt ahunt to find their hinnigen where Pappappapparrassannuaragheallachnatullaghmonganmacmacmacwh ackfalltherdebblenonthedubblandaddydoodled and anruly person creeked a jest. (FW, 332.4-7) $)^{23}$

Such was the act of goth stepping the tolk of Doolin, drain and plantage, wattle and daub, with you'll peel as I'll pale and we'll pull the boath toground togutter, testies touchwood and shenstone unto pop and puma, calf and condor, under all the gaauspices (incorporated), the chal and his chi, their roammerin over, gribgrobgrab reining trippetytrappty (so fore shault thou flow, else thy cavern hair!) to whom she (anit likenand please-thee!). Till sealump becamedump to bumpslump a lifflebed, (altolà allamarsch! O gué O gué!) (FW, 332.14-18)24

Joyce controla o ritmo do texto de forma que pulsem frases com tônicas bem definidas, formando o que ambienta o burburinho da noite no bar cheio e de pessoas em festa. Além das evidentes e numerosas aliterações, ao unir palavras, como em "becamedump to bumpslump" é criado todo um novo ritmo do início ao fim das enunciações. Além do forte impacto sonoro, a semântica é consequentemente modificada, deslocando-se o que seria um significado

\footnotetext{
22 "Pirlimpimpim. Da estorieta este é o fim. De uma pequerrucha hip e de um grande triscuna" (na tradução de Donaldo Schüler, 2003).

23 "Pois essazim e essezim ainda andam por aí a procura de Finn onde Pappappapparrassannuaragheallachnatullaghmonganmacmacmacwhackfalltherdebblenonthed ubblandaddydoodled e uma personalidade ilegal largou um gracejo" (idem).

24 "Tal foi o ato deusassombrado pra deter a fala do palanquim, drenagem e plantação, vime e barro, tua é a repulsa, meu é o pulso nosso é o impulso do barco à terra dos aterrados, testemunhas de madeira sapiencial e de pedra filosofal até pupa e puma, o bov hino e o condor sob todos os gaauspícios (incorporados), o cujo e seu ela perroeirando, caraagoraagarra reinando o trotedatropa (até aqui fluirás, ou te arrastarão pelos cabelos como na caverna!) a quem ela (não se assemelha, praza-te). Até que marulho se converta em entulho, o brusco baque no líffido leito, (altolá, allamarcha! O quê, o quê!)" (idem).
} 
previsível para um neologismo que não se fixa como neologismo, uma vez que continua podendo ser reinventado. Do trovão que possivelmente é o mais musical de todos, passamos até mesmo por Shakespeare ("shenstone"), aqui unido a Shem.

Retornando ao texto de Caetano Galindo, a aproximação entre Finnegans wake e música dá-se, então, pela possibilidade de pensar essa obra literária como uma partitura, lembrando, ainda, a sugestão do próprio Joyce, de que a leitura de sua obra era diferenciada se fosse feita em voz alta - executada como música escrita sobre as pautas de uma obra musical. Isso se relaciona diretamente a um certo papel atribuído ao leitor nessa interação menos passiva e mais ativamente investigativa ou analítica, em um sentido que é certamente mais inventivo do que interpretativo. Em vez de linhas, pautas. Sobre essa comparação, diz Caetano Galindo:

\footnotetext{
Uma partitura, por outro lado, jamais será vista como a "inauguração" de uma obra, privilégio que cabe a sua primeira execução pública. A partitura, afinal, é muito menos "a obra" que um detalhado conjunto de instruções para a realização da obra, que passa a existir apenas quando executada, que tem a capacidade de existir como tal e de afetar mesmo pessoas "analfabetas" no sistema de signos em que se escreve, que mantém com aquele autógrafo uma relação, portanto, necessariamente de maior independência. Hierarquicamente superior. E já naqueles primeiros poucos exemplos de "brincadeiras" sonoras do Wake, junto da constatação de que se trata de uma obra em que a leitura, e a leitura em voz alta, tem um papel completamente diferente na atribuição, na criação de seu sentido, fazem com que de diversas maneiras se possa sim pensar no livro como mais próximo de uma partitura. (GALINDO, 2010, p. 298)
}

A multiplicidade proporcionada por essa abertura não prejudica, portanto, a unidade da obra, nem significa abertura a qualquer interpretação; a abertura em questão é efetivamente de autonomia e participação do leitor, tomando decisões que efetivamente afetam sua experiência com a obra, não por sua evidente subjetividade como pessoa, mas em seu papel como destinatário - e não mero receptor de uma obra fechada cuja significação está dada, inerte. A essa abertura poderíamos então comparar a da música e seu efeito, que parte 
de um "desdém com o sentido", para usar expressão de Caetano Galindo. Mais do que relações de sonoridade com o uso de aliterações, assonâncias, rimas, que comumente relacionamos a uma certa qualidade musical (mas que são aspectos em geral inerentes a quaisquer textos literários), o texto tem um princípio estruturante diferenciado que assim o assemelha à música.

Essa aproximação diz respeito à maneira de interação que existe entre a obra e um intérprete de uma composição musical mais do que entre a obra e o seu ouvinte. Assim nos remetemos à aproximação feita por Eco entre o texto joyciano e a música moderna, que se justifica em diversos aspectos, entre os quais destacamos aqui o da necessária execução em uma certa sequência temporal como fundamento inerente às duas artes, música e literatura. Ambas são elaboradas a partir de uma ordenação que, se alterada, modifica-se, ao contrário de obras de arte com entrada livre. O componente temporal tem destaque de maneira evidente também no cinema; tem possibilidades diversas de entendimento na fotografia e nas artes plásticas; a partitura, no entanto, assim como o texto teatral, de outra maneira, também o é, faz parte do rol de peças executáveis. É das obras de arte que se escrevem e, inscritas, permanecem na promessa de que se deem em um novo tempo, em um acontecimento fora do papel.

Não falamos, portanto, tão somente de um texto literário musical, mas dos fundamentos compartilhados entre as duas artes, em termos fundamentais de elaboração e de acesso/execução/recepção, dentro da plasticidade de cada uma delas. A problemática inescapável que concerne à sucessão temporal como fator inato da obra não se refere, no texto literário, simplesmente à sequência de sons, mas a toda a matéria da obra. Como em certas obras musicais o compositor deixa a possibilidade de o(s) instrumentista(s) ou mesmo o(s) ouvinte(s) intercambiarem partes do todo, de forma, então, prevista e deliberada pelo autor em todas as suas consequências, temos em Finnegans wake a possibilidade de entrada por qualquer trecho. No entanto, assim como na obra musical as consequências são medidas, também no Wake existe, é claro, uma ordem subjacente, ainda que se possa ignorá-la no processo de leitura e iniciar de 
qualquer página. A leitura, ainda que executiva, é feita em cima de indicações pré-existentes.

O leitor ideal do Wake, por conseguinte, deve ser aquele indivíduo aberto a uma renovação inesgotável de processos cognitivos, aquele que não executa sua leitura preso a seus horizontes, mas está disposto a expandi-los a cada linha. A fluidez em Finnegans wake se deve ao não estabelecimento de uma voz que tenha lugar próprio. Como diz Derrida em "Duas palavras por Joyce”, há livros que terminamos de ler assim que iniciamos a leitura, enquanto James Joyce nos faz encarar a leitura que nunca parece ter fim. Muito frequentemente, Finnegans wake é lembrado por ser um livro circular, sendo essa uma das mais evidentes características da estrutura elaborada por Joyce. Podemos lembrar ainda a figura elíptica, como Derrida a concebe, para atestarmos que a circularidade wakiana não se engendra em reiteração cíclica, em regressos a pontos iniciáticos nem em repetições de processos idênticos. Ao contrário, a circularidade do Wake efetivamente se aproxima da viconiana, que inspirou Joyce: temos um processo de retorno que só é previsível até certo ponto, pois engendra, acima de tudo, a renovação de seus elementos. Assim, até nas repetições de um mesmo termo pela obra, podemos perceber como o que acontece não é a retomada pura e simples, mas a operação de uma différance, com "a", uma vez que o termo é aparentemente duplicado, mas não ocorre da mesma forma e, portanto, já não é idêntico em significado.

A relação com música novamente se faz proveitosa, por uma outra via de relação. Em um paralelismo bastante coerente, a respeito de como é possível a operação de leitura de uma obra como Finnegans wake, Umberto Eco tece comparações citando o compositor belga Henri Pousseur, um dos nomes da nouvelle musique, junto também de Luciano Berio, Pierre Boulez e Karlheinz Stockhausen.

Para definirmos a situação do leitor de Finnegans wake parece-nos servir perfeitamente a descrição dada por Pousseur da situação do indivíduo que ouve uma composição serial pós-dodecafônica: "Já que os fenômenos não mais estão concatenados uns aos outros segundo um determinismo consequente, cabe ao ouvinte colocar-se 
voluntariamente no centro de uma rede de relações inexauríveis, escolhendo, por assim dizer, ele próprio (embora ciente de que sua escolha é condicionada pelo objeto visado), seus graus de aproximação, seus pontos de encontro, sua escala de referências; é ele, agora, que se dispõe a utilizar simultaneamente a maior quantidade de graduações e de dimensões possíveis, a dinamizar, a multiplicar, a estender ao máximo seus instrumentos de assimilação". E com essa citação fica sublinhada, como se disto houvesse necessidade, a convergência de todo o nosso discurso para um ponto único de interesse, e a unidade da problemática da obra "aberta" no mundo contemporâneo. (ECO, 1989, p. 49)

Assim, a postura ativa se faz não somente numa via extra de interação obra-receptor, mas é efetivamente uma demanda, necessária para que essa interação possa se viabilizar. Ainda que ambiguidade e polissemia sejam evidentemente traços inerentes a quaisquer textos literários, em geral, há uma oferta disseminativa específica onde se engendra différance. A interação receptor-obra na qual a participação e as escolhas do leitor é uma necessidade tem uma dinâmica operacionalizante, que não somente ressuscita o texto morto na leitura, mas o faz quase podendo dá-lo à luz. Em consonância com o que é dito por Haroldo de Campos em $A$ arte no horizonte do provável, voltamos à Escritura do retorno: "A arte joycena, circular e em aberto, não possui como operador a figura autoral, mandatária. Antes, a informação estética - como transmissão de sensação da forma - é gerada pelo interpretante que assume a posição de operador" (EYBEN, 2012, p. 616).

Isso não implica, no entanto, é bom que lembremos, uma abertura semântica total e desgovernada, que nos leve a aquiescer para as suposições de que Finnegans wake seja uma grande piada, sem qualquer indício de que sua leitura valha a pena. Além de rascunhos e arquivos de Joyce apontarem fortemente para o contrário, com esquematizações da estrutura e registros das formulações de trechos reescritos e reeditados com precisão, vimos que não foram poucos os leitores que se dedicaram à incursão por essa obra, ainda que seja tão mal falada quanto se diz que é incompreensível. Não se trata apenas de frases compostas de um puro trava-língua sucedendo o outro, que não remetem a nada e têm seus significados encerrados em si mesmos, de forma que somente o significante seja manipulado em brincadeiras linguísticas - ainda que a 
comparação inicial seja relativamente cabível, no que diz respeito aos jogos fonéticos e trocadilhos que compõem a obra joyciana. O recurso não resulta em uma anulação da unidade significativa; ao contrário, temos sua expansão. Há críticos que traçam a sequência da intriga na obra e a analisam sob essa óptica; ainda assim, sabemos não haver linearidade narrativa na concepção tradicional de enredo, uma vez que o Wake traz o que se caracteriza pelo adjetivo plotless ${ }^{25}$.

Como lembra o próprio Eco mais à frente, porém, "Essa pluralidade semântica não determina ainda o valor estético" (ECO, 1989, p. 91). Fosse essa a matéria-prima de Finnegans wake, não seria composto, então, por mais que jogos intelectuais, e tantos críticos assim o julgaram. Se pluralidade semântica implica uma série definida de possibilidades a, b ou c para uma frase, expressão, capítulo ou para a obra toda, está mais longe de Finnegans wake do que supõe Eco. Polissemia subentende a possibilidade de visualizar nas palavras as possibilidades para as quais elas se abrem, como na ambiguidade, em geral, também se tem a consciência dos sentidos que povoam o mesmo território. Por mais contraditório que possa soar, isso ainda pode integrar, porém, uma leitura hermenêutica; substitui-se a noção de verdade contida em uma unidade pela de um espectro de verdades simultâneas, ainda controladas, detidas nos limites do horizonte que nossa visão alcança com nitidez.

Em vez disso, poderíamos - podemos - ler Finnegans wake sem necessariamente buscar conter em diagramas mentais os pontos semânticos oferecidos em cada expressão, não somente porque esse seria um trabalho cansativo, mas também porque não nos ofereceria garantias de ser esta a melhor maneira de intimidade com o texto. Da mesma maneira, ler com fluidez, ainda que uma ou outra referência possa nos escapar pelos dedos, não é necessariamente uma forma menos integrada de se deparar com a obra em questão. Fluidez, aqui, sublinhe-se, não se refere à suposição de que se tenha, diante das páginas do livro, um leitor passando por elas, uma a uma, de maneira

${ }^{25} \mathrm{O}$ termo vem do inglês plot, que se refere especificamente a enredo ou trama. O Wake não possui um enredo que mova a leitura e seja separável em situação inicial, clímax e desfecho, e mesmo os elementos básicos da narrativa - personagens, narradores, tempo e espaço - se modificam todo o tempo. 
homogênea, sem que se detenha em nada de específico, avançando ininterruptamente pelo texto em um ritmo padronizado, meramente decodificando palavras, lendo o texto somente no sentido mais simplório de assunção da existência e de certa compreensibilidade de um dado código. Referimo-nos, ao contrário, ao caso de um leitor qualquer se se lance à leitura do livro - de modo que detenha um tempo singular de sua própria leitura, que flui em seu ritmo próprio, individual, variável e incalculável.

Pelo fato de que o texto, como é tecido, exige do leitor a tomada de algumas decisões, já há demanda suficiente de uma postura ativa, que não precisa ser a tradicional postura de identificar todos os componentes e, assim, destrinchar todos os elementos do texto, por mais que isso eventualmente possa ser de grande ajuda. Talvez a noção do todo seja mais importante e mais difícil de ser alcançada, fora dessa análise a que estamos acostumados. Muito do texto, por mais hercúleo que o trabalho possa parecer, pode ser forçosamente colocado em diagramas e planilhas mentais, com divisões e classificações criadas a partir de moldes teóricos pré-existentes, mas lidar com o texto em sua complexidade é respeitá-lo na sua porção de problemática indecifrável. 
Capítulo II:

FINNEGANS WAKE E O TEMPO DA TRADUÇÃO 
No prefácio à tradução dos poemas de Charles Baudelaire reunidos na seção Tableaux parisiens, publicada em 1923, denominado "Die Aufgabe des Übersetzers", Walter Benjamin apresenta, nas palavras de Haroldo de Campos, a sua "metafísica, antes do que uma física da tradução" (CAMPOS, 2008, p. 179). Ao encetar sua exposição a respeito da "tarefa-renúncia do tradutor", como traduziu Susana Kampff Lages, Benjamin questiona qual o destino do texto traduzido, após afirmar o que aqui se traz como epígrafe: a compreensão — ou a tentativa de engendrar alguma - das obras de arte não deve se pautar pelo receptor. Enseja lembrar que se costuma entender a tradução limitando-se à visão corriqueira de que teria o objetivo precípuo ou mesmo único de facilitadora do acesso ao texto, o que recairia, justamente, no problema de ter no destinatário sua justificativa, focando na recepção do texto toda a necessidade de sua existência - ou, mais gravemente, a sua utilidade - e, portanto, tirar dessa relação suas premissas e direcionamentos. 
A existência de um problema em considerar a tradução como algo produzido tão somente para atender àqueles privados da compreensão do idioma do texto de partida antecede, contudo, qualquer afirmativa contra a exegese que se paute pela recepção ou a favor de qualquer fantasiologia em detrimento de uma investigação do patético schlegeliano ou do empírico em literatura. É possível perceber esse problema no apontamento do fato um tanto explícito de que o leitor da tradução que visa substituir o texto de partida inevitavelmente a lerá como texto original (no sentido de primeiro, evidentemente). As relações entre o texto de partida e suas traduções é perigosamente apagada no caso do leitor cujo contato com a obra se dá somente por uma tradução, especialmente entre aquelas que não contêm comentários, notas ou recursos similares por meio dos quais o tradutor aponte seus dilemas e exprima as dificuldades pelas quais passou, remetendo ao texto de partida, bem como que critérios utilizou em suas escolhas e renúncias lexicais ou sintáticas.

Além das peculiaridades inescapáveis da leitura de uma obra de tradução sem o concomitante acesso ao texto traduzido, existem, ainda, os problemas inerentes ao texto. Tradutores que se incumbem da tarefa de transmitir algum ato comunicativo a ser detectado no texto de partida, transportando uma mensagem - por vezes, artificialmente construída ou forçosamente encontrada, em uma leitura enviesada ou mesmo forjada - a outro idioma por meio do labor tradutório, estariam prestes a falhar, de certa maneira, ao menos segundo o que assevera Benjamin, ao recaírem na "tradução inexata de um conteúdo inessencial" (BENJAMIN, 2008, p. 66). A falha tem, é claro, nesse caso, um sentido específico, que parte da concepção que Benjamin traz de tradução. Seria demasiadamente penoso declarar ou apontar fracassos tradutórios completos a qualquer que seja a tentativa, ao menos em literatura, de traduzir algum texto. Como a Benjamin, porém, a compreensão do que significa ou qual a intenção do ato de traduzir literatura parece-nos primordial ao labor tradutório e também à leitura de traduções, pois esclarecer o ponto de que partimos ao olhar o texto: se é o mesmo ou se já é outro, que medidas há de "mesmo" e de "outro" ou de 
"inovação", algo que compreendemos por processos de diferenciação e similaridade.

"Die Aufgabe des Übersetzers" é um texto frequentemente referido como ensaio, a despeito de ser mais lógico e afirmativo do que essa classificação poderia implicar (isso talvez ocorra pela obsessão própria do século XX de enxergar Essayismus em variadas formas textuais e, em alguns autores, Möglichkeitsmenschen, ou "possibilitários", nos termos do escritor modernista austríaco Robert Musil, contemporâneo de Joyce). Benjamin transparece certo idealismo em seu conceito de língua pura e transita entre a construção desse conceito etéreo, à medida que o texto avança, e nuances de uma tradição platônica um tanto menos hesitante, mais sólida. Ainda assim, é clara a ratificação buscada pelo autor, de afirmar a tradução da arte tão dignificante quanto a criação artística per se.

Considerando-se um texto classificado como "literário", o dilema de como traduzir se torna especificamente (porém não necessariamente mais) complexo. Poder-se-ia considerar que a abertura do texto facilita a tarefa tradutória, uma vez que expande as possibilidades de escolhas, em vez de reduzir a correspondência de uma palavra a uma entrada dicionarizada ou opção lexical mais imediata. Traduzir literatura demanda meditar sobre um termo, mas também sobre a frase, a estrutura e o todo da obra. A expansão lexical engendrada em arte é, contudo, sintética; não há possibilidades quaisquer, de consequências equivalentes, mas, ao contrário, as consequências de uma escolha ou outra devem ser drasticamente distintas. A necessidade do mot juste do labor artístico literário permanece sendo uma demanda da tarefa tradutória e, nesse sentido, o tradutor, em um entendimento radical de sua prática, de alguma forma reescreve o texto de partida, tomando emprestadas a estrutura e as ideias do que traduz.

Esse é o princípio levado à risca com o termo transcriação, ainda que não se restrinja à modalidade concebida pelos irmãos Campos, que envolve ainda outros argumentos. A despeito da conação ou vocação artística putativa do tradutor, ou seu esforço em ser, também, poeta, a tradução de literatura lida com 
o fenômeno potencializado de cada termo ter alto impacto, seja o mot juste procurado pelo tradutor criativamente, seja buscado em metodologia que percorra caminho técnico-investigativo. Haroldo de Campos afirma a respeito das traduções do Panaroma do Finnegans wake (2001), “(...) o que interessa não é a literalidade do texto, mas, sobretudo, a fidelidade ao espírito, ao 'clima' joyciano, frente ao diverso feixe de possibilidades do material verbal manipulado" (CAMPOS, 2001, pp. 27-28). Essa fidelidade pode ser entendida como análoga à que Benjamin defende, que se engendra sendo fiel à forma do texto, destituindo-o da fidelidade ipsis litteris, isto é, daquela realizada de maneira literal, de vocábulo em vocábulo, apoiada na suposta função tradutória de transpor a mensagem comunicativa, considerada "inessencial". Em seu texto "Transluciferação mefistofáustica", Haroldo afirma que "Não seria descabido ultimar a teoria benjaminiana da tradução como portadora da mensagem 'inter' (ou 'trans') semiótica da língua pura, orientada pelo lema rebelionário do non serviam" (CAMPOS, 2008, p. 180).

Não há, nem deve haver, por conseguinte, expectativa de transposição entre planos em resultado tradutório calculável, desde que se admita que a tradução, como o texto de partida, não significa o mesmo que ele, mas é - deve ser em sua tautologia, como propõe Albercht Fabri. Se vemos o tangenciamento de Benjamin, devemos vislumbrar, no processo tradutório cerebral, o ponto a ser tocado entre a infinidade de pontos; não obstante, isso só pode permitir a dedução do horizonte da língua pura se for mantido o espaçamento da "pulsão dionisíaca que é capaz de dissolver a diamantização apolínea do original préformado em nova festa sígnica", pondo a "cristalografia em ebulição de lava" (CAMPOS, 2008, p. 180). Revela-se prejudicial o uso de termos similares a "mensagem", "mensageiro", pois afirma um binarismo de espaços, em que dois planos coexistem e, entre eles, ocorre o intercâmbio. Falar em "portadora de mensagem" só é cabível, nesse contexto, se referindo à "inter (ou trans) semiótica da língua pura" da fala de Haroldo, mas não ao que remete de forma mais imediata, o conteúdo inessencial - ao invés da categoria da forma, que caracteriza a tradução na teoria benjaminiana. 
Admitiríamos, assim, a possibilidade de o receptor da tradução ser um leitor capaz de acessar o original, de forma que a tradução seja um texto adicional ao invés de atuar como um usurpador do estatuto de texto primeiro. Mais do que uma possibilidade, o leitor ideal da tradução seria esse, que pode vê-la como fonte de variantes interpretativas provenientes de leitura singular do texto, feita pelo tradutor (um leitor ideal, sob essa óptica). A palavra para "tradução" na língua alemã é Übersetzung, junção do prefixo (do tipo que tem valor semântico também por si só) über com a palavra setzung, significando uma sobreposição, sobreaplicação. Indica uma sobre-escrit(ur)a, uma sobrevivência. O leitor da tradução que tem acesso ao original - o que definimos como o leitor ideal da tradução - e sua leitura do texto de partida e do que the foi sobre-escrito é outro argumento a favor da tradução criativa e ratifica a possibilidade de o labor tradutório poder e dever ser executado como arte, conferindo ao tradutor não somente status, mas responsabilidade. Não só pode se dedicar à busca do mot juste, como se incumbe desse dever ao se prestar à tradução.

Walter Benjamin afirma o estatuto da tradução como forma que não se rende ao papel de transpor significados de um idioma a outro, libertando-a de qualquer caráter submisso ao texto traduzido. No entanto, isso não significa forçar uma desvinculação. Ao contrário, afirma que "é preciso retornar ao original" (BENJAMIN, 2008, p. 67). Os quatro tradutores do texto de Benjamin Fernando Camacho, Karlheinz Barck (e equipe... não nomeada) Susana Kampff Lages e João Barrento - optam pelos termos "retornar" ou "regressar", "o regresso". No entanto, pensar em voltar-se ao que é o texto original explicitaria como isso significa o ato literal de, como leitor do texto de partida, debruçar-se, considerando como o tradutor deve, é óbvio, ir a ele, não somente em um regresso simbólico, mas também como parte efetiva do processo de tradução. A concisa expressão do movimento de voltar-se aponta também para a necessidade de evocá-lo no texto resultante da tradução, ainda que não seja servil a ele e, por último, aponta para o retorno à língua pura, una, babélica, aquela em que não há a categoria do enunciado e que ultrapassa as línguas nacionais. 
A tradução, para Walter Benjamin, é intraduzível. Esse fato confirma sua autotelia. O tradutor é fiel na medida em que produz devir em seu idioma, de forma fiel à que o escritor do texto de partida o fez em sua língua. Se pensarmos que uma obra literária pode ter como qualidade inerente a ela, segundo Benjamin, sua traduzibilidade, a observação tão comum a respeito de Finnegans wake vem à tona: essa obra, considerada através dos tempos de ilegível a intraduzível, teria que nível de traduzibilidade? Como questiona Lenita Esteves no terceiro capítulo de sua tese: "Mas, da mesma forma que Derrida aponta para um certo aspecto risível da pergunta: 'Você já leu Joyce?', podemos achar engraçada a pergunta: 'Alguém já traduziu Finnegans Wake?"' (ESTEVES, 1999 , p. 83). Frequentemente se afirma que o idioma dessa obra de James Joyce não é o inglês, mas um outro, limitado ao livro e nele desenvolvido, elaborado pelo autor a partir de idiomas diversos. Consideremos, então, que Finnegans wake (1939) possui - ou melhor, produz, engendra uma língua da própria obra. Isso significaria não apenas que a tradução deve fazer o mesmo, mas também que esse idioma próprio tem no texto as definições de suas especificidades, as diretrizes de seus parâmetros e a que princípios está submetido.

Não poderíamos afirmar o mesmo, no entanto, a respeito de todo e qualquer texto literário? Finnegans wake apresenta de forma radicalmente explícita e elaborada com extrema acuidade o que toda a Literatura, todo e qualquer texto-arte traz intacto em sua essência: uma língua própria, um dizer que não se repete no linguajar cotidiano, tampouco em outros autores, ainda menos em textos técnicos, dissertativos, científicos. Podemos entender, destarte, a essência antitética da tarefa de traduzir literatura, cujos alicerces são os dois fatos concorrentes de que o texto literário recusa-se a uma transposição de seus significados, a uma tradução entendida como produtora de alguma equivalência, e o de que também demanda que seja traduzido, em tendo traduzibilidade inerente, de maneira diferente ou em outro grau que não pertence a uma traduzibilidade de sentido, de mensagem, de comunicação. A tradução de literatura, portanto, de texto que produza em sua tessitura uma linguagem própria, enquadrada em sua fôrma, exige, efetivamente, a criação de mais uma 
língua própria tecida textualmente, já que existirá outro texto, ou nova versão do texto que se intenta traduzir. Esse fator inescapável, por conseguinte, faz necessário que, inspirando-se no "idioma próprio do texto" de partida, o tradutor se lance a realizar alguma espécie de criação no idioma para o qual traduz, ainda que não seja um seguidor dos caminhos de liberdade apontados pela transcriação.

A tradução de literatura difere-se ainda por outro fator que não diz respeito a sua feitura, mas reside no que excede sua elaboração: o acometimento de certa direção na recepção e na crítica do texto, em distintas heranças escolhidas. É nítido em Finnegans wake o quanto seus principais tradutores brasileiros Augusto de Campos, Haroldo de Campos e o professor Donaldo Schüler encaram a obra como radical, além de efetivamente concordarem com o fato de que sua complexidade torna a tradução tanto mais difícil quanto profícua. "Finnegans wake é 100\% de inovação linguística. Nenhuma concessão. Nenhum recuo" (CAMPOS, 2001, p. 21). Na introdução do primeiro volume de sua tradução, Donaldo Schüler: "Distanciamo-nos com frequência da literalidade para captar efeitos que ultrapassam significados. (...) Num discurso deliberadamente onírico, luminosidade intensa não se atingirá nunca" (SCHÜLER, 2004, p. 25). Em texto publicado no Panaroma e também na coletânea Teoria da poesia concreta, Haroldo de Campos afirma: "Traduzir James Joyce, especialmente fragmentos de Finnegans wake, é uma ginástica com a palavra: um trabalho de perfeccionismo. Algo que nunca assume 0 aparato estático do definitivo" (CAMPOS, 2001, p. 27).

Apesar das semelhanças, ambas as traduções, tanto a de Panaroma do Finnegans wake, cuja primeira edição data de 1962, quanto a de Finnegans wake/Finnicius revém (2004), implicam recepções (pré e pós-tradução) distintas e empregam diferentes instrumentos para lidar com as possibilidades do texto de partida. Os irmãos Campos optam pela tradução que chamam de intensiva (ao invés de extensiva), colhendo trechos que demonstrem o potencial radical do texto como um todo. "O nosso objetivo sempre foi o de trabalhar e lapidar alguns dos momentos mágicos do livro, e somente dar a público aqueles que, em nosso entender, oferecessem, em português, um estatuto equivalente à alta 
voltagem de invenção e criatividade do original. Trabalho de concentração" (CAMPOS, 2001, p. 21).

Schüler, por outro lado, algumas décadas depois, opta pela tradução integral e, portanto, por aquela que tenderia ao que Augusto de Campos e Haroldo de Campos então denominaram extensiva, ainda que o labor de Donaldo Schüler não deixe de ser, também, de intensidade sobre o texto: debruçou-se sobre cada fragmento, dedicando-se a cada um, separadamente, gradualmente como uma obra por si. Alerta: "Para se fazer entendido, o texto oferece muitas versões do mesmo código cifrado" (SCHÜLER, 2008, p. 24). Como Joyce, nas palavras dos irmãos Campos, não faz concessões, o tradutor afirma seguir o mesmo caminho de não simplificar e recomenda leitura que se submeta aos mesmos riscos: "Vencida a vertigem ante frequentes abismos, somos estimulados a criar roteiros próprios. (...) Não se espere, assim, inteligibilidade completa do texto" (Ibid., p. 25).

Se a tradução intensiva, portanto, dá a entender a potenciação de um esforço vertical, de imersão, aplica-se também à metodologia de Donaldo, que percorre fragmento a fragmento, traduzindo criativamente. Cumpre a missão predita por Lenita Esteves em sua tese, anos antes da publicação completa da tradução de Schüler: "Mas, da mesma forma que Derrida aponta para um certo aspecto risível da pergunta: 'Você já leu Joyce?', podemos achar engraçada a pergunta: "Alguém já traduziu Finnegans wake?". Traduziu de que língua para que outra? Se, como afirmam alguns autores, Joyce fragmentou, quebrou, desmantelou a língua inglesa, o tradutor terá também que compor um texto desmantelando sua língua" (ESTEVES, 1999, p. 83). A língua portuguesa é, então, invadida - não invalidada, mas povoada - por um texto wakiano, em vez de prestar-se ao trabalho de verter de cá para lá; é, também, como o inglês o foi, alterada, habitada pela literatura que a torce e a desorienta. Uma enxurrada invade com correnteza violenta a língua para a qual se verte enquanto a linguagem segue o fluxo que não é margeado por delimitações gramaticais, mas, ao contrário, gera a erosão dessas fronteiras. 
Comparando as duas traduções do primeiro fragmento de Finnegans wake das edições supracitadas, podemos perceber como versões de um texto tão radical, que optam por soluções tradutórias distintas, resultam em dois textos consideravelmente diferentes entre si, ainda que ambas partam do princípio de serem traduções para a língua portuguesa e que tenham sido feitas por brasileiros. Na primeira linha, por exemplo:

riverrun, past Eve and Adam's (FW, 3.1).

Observa-se que "past ____ (o termo past seguido de um complemento direto, portanto) pode significar algo como "após", em português, porém tanto temporalmente, referindo-se a uma sequência cronológica, quanto espacialmente, indicando uma passagem, no caso, pela igreja Adam and Eve, em Dublin. A inversão no nome do local indica uma subversão e, portanto, uma impossibilidade de se decidir entre o sentido de passar pela igreja ou de passar o tempo de Adão e Eva, indicado também pelo termo "past", que carrega traços semânticos relacionados a tempo. A demanda da coexistência dessas duas possibilidades, portanto, é um desafio tradutório que se impõe já no primeiro período da obra. A tradução de Augusto de Campos opta por direcionar o olhar à ideia temporal:

riocorrente, depois de Eva e Adão (CAMPOS, 2001, p. 41)

Além do uso do termo "depois", também relacionado a tempo, prioritariamente, como o "past" do texto de partida, mas também possível de se referir ao deslocamento no espaço, a ausência de artigo antes de "Eva e Adão" esconderia a possibilidade de pensar no local, na construção - na igreja específica (algo que, em inglês, já que não admitiria artigo, é indicado pelo uso de apóstrofe + "s" do possessivo). Assim, poderia ser, talvez, mais imediato 
pensar em "Eva e Adão" como algo que seja mais que somente os dois personagens bíblicos se estivesse escrito, digamos, "depois da Eva e Adão", de forma que o artigo indicasse haver uma elipse (função que é cumprida, no texto de Joyce, pelo possessivo marcado com 's).

Quanto à opção posterior de Donaldo Schüler (2002), perlustrando uma outra via tradutória, pode-se dizer que visa explicitar essa possibilidade de leitura mais difícil de ser captada - especialmente pelo leitor não irlandês, que não terá a referência do nome dessa igreja em mente e tirando a vírgula:

rolarriuanna e passa por Nossenhora d'Ohmem's

Manteve-se, então, na tradução de Schüler, a referência ao catolicismo, ainda que agora seja à Nossa Senhora do Ó. A opção aqui, trazendo à sentença uma imagem relacionada à prática religiosa na Península Ibérica e no Brasil, foi a de ser fiel ao "espírito" joyciano - no termo dos irmãos Campos, herdado da ideia de Ezra Pound - no que se refere à proposta de universalidade, a despeito das referências a uma cidade específica. Finnegans wake faz do mapa de Dublin uma referência a tudo aquilo que ultrapassa quaisquer limites geográficos. Há, em Salvador, no bairro de Paripe, uma Igreja de Nossa Senhora do Ó: uma das primeiras paróquias fundadas na colônia portuguesa, data do século XVI. O marco iniciático de Adão e Eva, isto é, a semântica do ab initio se reverbera nessa marcação histórica em território brasileiro. Deve-se lembrar que a tradução por "Nossenhora d 'Ohmem's" não se amarra a esse ponto geográfico, uma vez que existem diversas paróquias dedicadas a essa mesma Santa por todo o Brasil, em Portugal e na Espanha. Podemos perceber, ademais, nessa mesma expressão que traduziria, a princípio, um mero nome de igreja - em Joyce, nada é meramente um nome - , a presença do personagem HCE: todos os homens, Here Comes Everybody (entre tantos outros arrolamentos), mostrase na aglutinação de Ó com Homem = Ohmem, que reverbera, ainda, um possível "amém". A vírgula após riverrun foi trocada pela conjunção aditiva, mas 
a vírgula após Adam's manteve-se a mesma após Ohmem's, que foi grafado com "m" no final e apóstrofe $+\mathrm{s}$, assim como é o nome masculino, o de Adão, em inglês.

A respeito das referências presentes na obra do escritor irlandês, Donaldo Schüler diz: "Não há página em FW sem evocações literárias - as bíblicas superam todas - , como se Joyce quisesse abarcar tudo o que se escreveu, fazendo de todos os textos um livro só" (SCHÜLER, 2004, p. 20). Esse ideal extremo de condensação traz uma possibilidade ou um anseio de superação do tempo: reunindo todas as obras já escritas em uma só, supera-se o que o tempo apaga, o que a distância cronológica segrega. A literatura pode ser pensada, então, em seu caráter trans-histórico, como afirma o fenomenólogo francês Paul Ricoeur em Tempo e narrativa, na medida em que se eleva sobre as divisões do tempo histórico e cronológico de modo que se faz de toda a história da literatura um acontecimento contemporâneo, discorrendo sobre o tempo do calendário "entre o tempo vivido e o tempo universal", com Benveniste, a partir das noções de tempo linguístico:

Contudo, embora a contagem do tempo do calendário esteja apoiada nos fenômenos astronômicos que dão sentido à noção de tempo físico, o princípio da divisão do tempo do calendário escapa à física e à astronomia (...) A originalidade que o tempo axial confere ao tempo do calendário autoriza a declarar este último "exterior" tanto ao tempo físico como ao tempo vivido. Por um lado, todos os instantes são candidatos legítimos ao papel de momento axial. Por outro, não há nada que diga que determinado dia do calendário tomado em si mesmo é passado, presente ou futuro (...) Para ter presente, como também aprendemos com Benveniste, é preciso que alguém fale; o presente é o discurso que o enuncia; para chegar ao tempo vivido a partir do tempo crônico é portanto preciso passar pelo tempo linguístico, referido ao discurso; é por isso que determinada data, completa e explícita, não pode ser dita nem futura nem passada se ignorarmos a data da enunciação que a pronuncia. (RICOEUR, 2012, pp.182-184)

De alguma maneira, a Odisseia de Homero é passível de ser entendida contiguamente ao Ulysses de Joyce, assim como ocorreria, então, com as referências contidas em Finnegans wake, desde as bíblicas, passando por Tristão e Isolda, lendas irlandesas e tantas outras referências histórico-culturais. 
Um eterno retorno na literatura em vez de uma história literária linear ou periódica: os efeitos de uma obra não têm início ou fim, mas engendram um impacto que se espirala, alastra-se através do tempo sem uma chegada.

O texto lançado à tradução atinge em concretude a possibilidade de seu desdobramento, multiplicado à medida que várias traduções coexistam. Haver mais de uma tradução para um mesmo fragmento de Finnegans wake, ou para qualquer outro texto literário, só adiciona: em vez de se anularem ou se contradizerem, muito mais provavelmente se complementam. Serão distintas por mais parecidas que sejam, transformando o texto de partida em variados outros, que não lhe são alheios, tampouco lhe equivalem. Traduzir é frequentemente entendida, em senso comum, como uma atividade verbal geradora de equidade, como o transportar das letras de um idioma a outro. Intercambiar idiomas, no entanto, implica a mudança de paradigmas - não apenas pela existência de fenômenos linguísticos relacionados a certa constituição social e cultural, que existem e variam mesmo em um só idioma, mas também de acordo com os diferentes parâmetros (no sentido chomskyano), isto é, possibilidades efetivas de expressão que a organização de determinado sistema verbal proporciona. Paralelamente ao ipsis litteris, portanto, compreendemos a tradução como uma (tentativa de) equivalência imperfeita a priori - ou, em vez de equidade, como uma renovação ou um desdobramento, em tese, infinito. Isso sem que perda de vista que há, como diz Benjamin, uma tangência na qual a relação entre o texto de partida e a sua tradução se relacionam, sem que haja uma transparência ou um espelhamento entre os dois, um sobre o outro ou um frente ao outro, mas sim uma união tangencial de dois textos distintos.

Tendo em mente esses procedimentos e o exemplo dos brilhantes resultados do trabalho dos irmãos Campos e do de Schüler, ensejaria a pergunta: uma boa tradução deve entender 0 ato tradutório dessa forma disseminadora para produzir algo tão rico quanto se afirma que uma tradução pode alcançar, devendo ansiar por tal resultado? Ou, em outras palavras: a tradução é tudo isso ou, sob certas condições demarcadas, concernentes a uma metodologia e a uma postura diante de sua feitura, pode sê-lo? A mesma pergunta permanece pairando a respeito da arte e da definição de texto literário. 
A busca por saber que texto é "boa" literatura e que texto sequer é "literário", afora a prova do tempo, que inclui ou exclui obras de um cânone, atrai diversas respostas. O que podemos ratificar é que as traduções que partam da noção de ato comunicativo, de exegese una, de uma interpretação fechada do texto, ainda que não tenham como objetivo transparecer algo de incomunicável do texto literário, poderão, porventura, fazê-lo - como que carregando algo do texto de partida sem nem perceber. Ou, se pensarmos de maneira um tanto mais pessimista, apenas destruirão a relação ideal, etérea e fugitiva com o texto de partida, não sendo fiel a seu espírito e ao que faz dele uma peça de arte, e funcionarão como exercício de tradução, intentando sinonímia impossível e concretizando mera paráfrase que, talvez, extirpe o caráter literário, artístico que havia outrora no texto de partida.

Em "Untranslatable you", Shireen Patell sintetiza um caráter duplo do trabalho de tradução: "The task of the translator (...) is at once an act of mourning and na ethical practice, because it is a task dictated by an absolute alterity that signals both loss and law without calculus" (PATELL, 2005, p. 899) ${ }^{26}$. Patell lembra ainda Derrida no que diz respeito ao fato de que a tradução não é uma relação intersubjetiva ou interpessoal, mas grafemática. Há uma diferença entre a assinatura e quem assina; no caso da tradução, essa diferença se explicita na distância entre o tradutor e aquilo com o que se compromete em nome de algo: o texto e a assinatura têm sobrevida. Ainda que haja uma dificuldade em determinar a autoria de um texto traduzido, se autor ou tradutor ou se uma combinação, emerge uma assinatura nova.

As mesmas perguntas a respeito da ilegibilidade de Finnegans wake se fazem quanto à sua traduzibilidade ou às possibilidades tradutórias que pode oferecer. O fato é que o texto possui uma riqueza nesse sentido, tendo sido produzidas excelentes traduções e havendo ainda uma proficuidade para novas tentativas. Traduzido por Augusto de Campos, Haroldo de Campos, Donaldo Schüler e tantos outros mais que possam ter se aventurado, bem como, tangencialmente, por Caetano Galindo, que traduziu Finn's Hotel, texto de Joyce

26 "A tarefa do/a tradutor/a é, ao mesmo tempo, um ato de luto e uma prática ética, porque é uma tarefa comandada por uma alteridade absoluta que assinala tanto perda quanto lei sem cálculo." 
escrito entre Finnegans wake e Ulysses que parece ter sido uma espécie de rascunho do que seria o Wake, ou talvez uma obra independente com algumas pontes, ou treinos, ou inspirações de Joyce; sobre o trabalho de traduzir Joyce, em Finn's hotel (2014), diz Galindo: “[Joyce] Cobra que você fuce em cantos do português que normalmente ficam ali só pegando pó. É, em suma, um imenso prazer para quem tem esse tipo de perversão" (p. 11) - e aqui lembramos o que diz Seamus Deane, excerto já citado em capítulo anterior: "[The book] converts itself into English and perverts itself from English". (DEANE, 2000, p. viii). Tanto a escrita de Joyce quanto a tradução de seu texto, sendo perversões do idioma (ou de idiomas), não poderiam caber em definições de tradução como reprodução exata, pois exige torções para que se exprima "conteúdo essencial".

Assim como os exemplos tradutórios aqui citados podem relativizar certas afirmações se considerarmos, em vez deles, traduções que não tenham sido executadas com o mesmo esmero, o texto literário de partida aqui referenciado tem a mesma consequência. Finnegans wake se caracteriza como uma literatura considerada radical - por vezes foi considerado texto ilegível e subestimado como mera brincadeira intelectual - e, dessa forma, é paradigma ideal para exemplificar o caráter etéreo que propomos como o que um texto tem de intraduzível. No entanto, como dito anteriormente, o que se entende por literário em Finnegans wake vale para todo e qualquer texto-arte, poesia, romancepoema etc., independentemente do gênero literário.

A problemática dos nomes próprios em Finnegans wake pontua uma dificuldade peculiar em sua tradução. Os nomes das personagens mudam a todo o tempo, sem haver qualquer previsibilidade, ainda que sempre haja pistas para que o leitor reconheça as relações. Poder-se-ia dizer que não somente os nomes sofrem mutações, mas os próprios seres. HCE e ALP aparecem em siglas em frases diversas, enquanto Isobel tem sua vogal trocada ou é chamada por variações diversas de seu apelido, Issy, ou na forma de Nuvoletta; Shem e Shaun mudam para combinações ainda mais distantes, como Mutt e Jute, Burrus e Caseous, Mercius e Justius, Dolph e Kev, sempre na reminiscência do duplo ambivalente. Essas mudanças de assinaturas reverberam a condição mesma das personagens no que estiver acontecendo a cada momento. 
Traduzir é não solidificar — não há tradução última, ainda que possa haver uma melhor que outra(s) —, mas lançar, jogar um jogo de azar: aposta-se em uma possibilidade, existente entre infindas outras, e se destrinça o resultado. Será acertado, é provável, ainda que não seja. Poderia ser 1, mas foi 2. Seria igual se fosse 3 -igual, mas diferente. Tal entendimento não resolve a tradução, não a define de forma a esquecermos os problemas que acarreta. Ao contrário, entendê-la como um enredamento problemático antes de tudo permite fundá-la como texto-fonte de discussão tanto quanto seu texto de partida. Os nós tradutórios deixam de sê-lo exclusivamente para, em vez disso, enriquecerem toda a constelação do texto (o texto de partida e suas traduções coexistentes), especialmente se literário, filosófico ou, de forma geral, ensaístico, adicionando discussão no próprio corpus do que é posto em pauta. Pode-se ler a tradução como crítica, como ensaio, como resenha, como resumo, como paráfrase: ela pode transparecer todas essas formas de expressão de um texto, sendo ela mesma outro texto, em vez de gênero objetivo. Uma (boa?) tradução condensa uma paideuma, espremendo uma impressão ao mesmo tempo em que exprime uma compreensão. A eventual dificuldade existente em se valorar uma obra literária como boa (ou mesmo como literária) pode ser a mesma de se valorar a tradução, mas seus valores podem variar de acordo com as pautas que propõe, com as suas premissas, além de ela mesma transparecer uma certa leitura ou visão do texto de partida através das decisões tradutórias e das criações que o/a tradutor/a possa se permitir ao trabalhar (sobre) o texto.

Sem desconsiderar dificuldades específicas inerentes e inegáveis ao texto de James Joyce, dilemas tradutórios no Wake podem ser dilemas tradutórios compartilhados, em geral, por toda e qualquer empreitada de tradução de textos escriturais. A literatura, em geral, parecendo mais ou menos complexa, mais ou menos legível e compreensível, demanda o cuidado detalhado e rigoroso e, por isso, impõe dificuldades incontornáveis e, em verdade, sem solução que as extermine, por mais que se tente traduzir de diversas maneiras e por mais notas de rodapé que se preencham. Referindo-nos especificamente ao próprio Finnegans wake, citamos novamente o texto de Shireen Patell — em que ela fala sobre todo e qualquer texto possivelmente intraduzível: 
What cannot be translated calls for the future translations that perpetually reach toward but can only trace an oblique if missed touch (...) Absolute untranslatability is the silent articulation of the absent ideality of translation that nonetheless inspires translation, figuration, writing. This absolute translatability is in and of the language itself. (PATELL, 2005, p. 901) ${ }^{27}$

Ademais, mesmo admitindo certa dificuldade específica inerente ao Finnegans wake, seja entre a tradução de nomes de personagens, seja na dos trovões de cem letras que povoam todo o livro - e que frequentemente são mantidos sem tradução - , defende-se aqui uma postura necessária diante de qualquer obra literária. Pode-se evocar aqui um trecho de Jacques Derrida, em seu livro De la grammatologie, discorrendo sobre as afirmações a respeito da linguagem de Jean-Jacques Rousseau no texto "Gênese e escritura do Essai sur l'origine": "Não haverá nem uma linha histórica nem um quadro imóvel das línguas. (...) As línguas são semeadas" (DERRIDA, 2011, p. 263). Essa citação pode contribuir aqui como uma explicação do dinamismo babélico do próprio Wake, que lida com línguas sem delimitação, suficientemente inseridas em fluidez de hibridização e fusão, sendo semeadas e, assim, portanto, germinando no fértil suporte, terreno do texto. Estende-se, porém, a qualquer escritura que contenha em si uma gagueira, para falar com Gilles Deleuze, ou qualquer texto feito a partir de uma língua contendo algum nível de estranhamento diante da própria língua, atuando na sua fronteira. Ainda que não haja o trabalho de confronto ou um fenômeno de clash entre diferentes idiomas, uma língua jamais está ausente de relações com outras línguas que vieram antes, depois, que ocuparam terras próximas ou distantes. Mesmo que não sejam fundidos explicitamente dezenas de diferentes idiomas, como faz Joyce no Wake, nenhum texto é isolado em sua língua.

27 "O que não pode ser traduzido demanda futuras traduções que perpetuamente se direcionam mas só podem rastrear um oblíquo ou mesmo perdido toque (...) Intraduzibilidade absoluta é a articulação silenciosa que inspira, porém, tradução, figuração, escrita. Essa absoluta intraduzibilidade está na e é da língua ela mesma." 
Tal postura tradutória já seria suficiente para nos apartar do labor braçal de buscar definições dicionarizadas como sinônimo de tradução. Essa maneira de ida ao texto se relaciona não somente com o resultado que surgirá da tradução, mas começa na forma de leitura do texto de partida, na maneira como é abordado pela primeira vez - não somente pelo leitor que lê com intenção e olhos de tradutor, mas por qualquer outro. Se o que se busca é a univocidade, a definição, a análise estrutural perfeita, com blocos conceituais relacionados a cada porção do texto e metáforas delineadas a serem circuladas, a babelização do texto será, então, deixada de lado. A tradução pautada por uma simplificação ou univocidade semântica, por reestruturação, deriva de uma leitura hermenêutica. Se a gagueira do texto de partida é ignorada, certamente não aparecerá nem transparecerá qualquer tipo de gagueira no texto derivado, "traduzido"; a gagueira que habita a tradução é resultado da relação primária no sentido de primeira - do tradutor com o texto que se propõe a traduzir, recriar ou transcriar, em uma postura de leitor disposto a vivê-lo em vez de entendê-lo. Disposto a ter uma experiência com sua linguagem muito antes de tencionar destrinchá-lo. 
Capítulo III:

LEITURA, LUTO, ELIPSE 
Ao pensarmos em Finnegans wake, seja tendo um conhecimento distante, fragmentado ou superficial a seu respeito, seja após tentativas de aproximação da obra, uma série de questões inevitavelmente nos consomem; em verdade, continuam a aparecer mesmo durante a entrega a uma leitura profunda desse texto impossível de se explorar de forma acelerada ou submetida a prazos, dados os obstáculos que nos prendem por um tempo sempre maior que o previsto em um parágrafo, em uma linha ou em uma só enigmática palavra. Uma leitura célere, ainda que permita terminar de ler o livro integralmente, é uma leitura desperdiçada. Em se tratando de Finnegans wake, a concepção do livro é clara quanto a mais valer o deter-se sobre uma linha que se mostre inebriante do que o impaciente passar de páginas, insistentemente evocando uma leitura fluida em velocidade que, provavelmente, terá sido forçada e pouco proveitosa. 
Essa escolha de Joyce aponta, como sabemos e logicamente podemos supor, a estrutura circular do livro. No entanto, essa expressão não pode se findar em si mesma, sendo banalizada, significando nada para além dela. Devemos, antes de tudo, questionar a esse respeito, a fim de investigar o que algumas análises afirmam como verdades que se apresentam integrais quando, de fato, são geradoras de problemas diversos. Pergunta-se então: quais as implicações de uma estrutura circular? Essa estrutura é verdadeiramente possível, em todos os aspectos que seriam forçosamente decorrentes de sua concepção?

É oportuno relembrar aqui Umberto Eco citando Henri Pousseur, que indica caber "ao ouvinte colocar-se voluntariamente no centro de uma rede de relações inexauríveis" (ECO, 1989, p. 49), não havendo amarras que determinem o caminho da leitura. Uma espécie de maior livre-arbítrio se instala necessariamente diante da falta de um caminho fechado, como se, em vez de percorrer um corredor, o leitor se encontrasse em um labirinto. Esse labirinto, é claro, foi projetado, de modo que suas curvas e becos foram, pelo menos até certo ponto, tranquilamente previstos. Com a multiplicidade de caminhos oferecida nessa arquitetura, no entanto, em oposição à unidade do caminho linear, há uma medida de imprevisibilidade, por mais meticulosamente planejado que esse labirinto seja: a ordem de cada escolha do indivíduo que vai percorrer seu terreno.

Outras referências feitas por Umberto Eco se fazem necessárias no que concerne à porção fenomenológica de toda essa problemática. Em uma leitura desse tipo, podemos considerar uma esquemática que envolva a consciência do sujeito-leitor diante da obra que, aí, é o que percebe como fenômeno consciência que, por ser instável, isto é, no sentido de uma consciência não-ideal não ser plenamente pré-delimitada, mas sim aberta a mutações imprevisíveis e que, portanto, não nos permitiria calcular previamente todas as possibilidades de interação com a obra em um quadro finito e fechado. Umberto Eco desenvolve esse ponto com as seguintes observações: 
Assim, um objeto não somente apresenta diversas Abschattungen (ou perfis), mas são possíveis diversos pontos de vista sobre uma única Abschattung. $\mathrm{O}$ objeto, para ser definido, deve ser transcendido em direção à série total da qual ele, enquanto uma das possíveis aparições, é membro. Nesse sentido, ao dualismo tradicional ser e parecer substitui-se uma bipolaridade de finito e infinito, de tal modo que o infinito se põe no próprio coração do finito. (...) O problema da relação do fenômeno com seu fundamento ontológico, dentro de uma perspectiva de abertura perceptiva, transforma-se no problema de relação do fenômeno com a plurivalência das percepções que dele podemos ter. (Ibid., pp. 58-59)

Dessa maneira, no esteio dessas afirmações, se nós tomarmos em consideração as possibilidades de que uma obra como Finnegans wake demande não somente uma apreciação passiva, decodificando primariamente 0 texto, mas acima de tudo uma interação de caráter até mesmo mais executivo, se assim pudéssemos dizer, seria necessário, no mínimo, considerar que essa posição ativa será ocupada por um leitor que tem sua própria bagagem subjetiva. Não colocamos em questão aqui uma bagagem de conhecimento objetivo necessário para um entendimento de leitura, nem nada nesse esteio; ao contrário, ao invés de uma espécie de elitização, um acesso democrático permite que qualquer indivíduo se ponha à fruição da literatura, da maneira como puder acessá-la. O que levamos em conta é o caráter fenomenológico dessa interação, observando que essa interação com a obra terá algo de único para cada consciência que a perceba e que tome atitudes frente a ela. Umberto Eco, continuando seu raciocínio a respeito desse fundamento ontológico na abertura perceptiva, cita excerto de Phénomenologie de la perception, de Maurice Merleau-Ponty:

A contradição que encontramos entre a realidade do mundo e seu inacabamento é a própria contradição entre a ubiquidade da consciência e seu engajar-se num campo de presença... (...) A consciência, que passa pelo lugar da clareza, é, ao contrário, o próprio lugar do equívoco. (...) É portanto essencial à coisa e ao mundo apresentarem-se como "abertos"... prometer sempre "algo mais a ver". (MERLEAU-PONTY apud ECO, 1989, p. 59) 
Estruturalmente, poderíamos, então, esquematizar três possibilidades de leitura do Finnegans wake, todas coerentes com a consideração de uma estrutura circular. A primeira é, a despeito da assunção da circularidade, a que se pode fazer seguindo a ordem da numeração dos fragmentos. Essa é uma leitura linear tanto quanto uma segunda possibilidade, em que se acessaria a obra de qualquer fragmento, ignorando a determinação do início do livro com o número 1, e se seguiria a leitura a partir da página escolhida, na ordem colocada - escolhendo, por exemplo, o fragmento 429 para ser o primeiro e seguir a leitura até o de número 628, em seguida do número 1 até o número 428. Essas duas possibilidades diferem radicalmente de uma terceira, que seria a de ler os fragmentos em qualquer ordem, anarquizando completamente a obra e tirando dela boa parte do sentido. Ler Finnegans wake fora de ordem é o mesmo que ler qualquer outro livro de que se tem conhecimento fora de ordem, assim como é o mesmo que percorrer um círculo dando passos adiante, voltando, seguindo, desviando: é uma leitura anárquica que extermina o que a obra tem a oferecer como obra una e total.

Excluindo, então, a terceira forma de leitura, esclarecemos que os fragmentos não são absolutamente isolados entre si e nem intercambiáveis ao menos não sem sérias consequências para a coerência da obra e para o acesso a ela como foi concebida em sua integridade. Os fragmentos guardam tanta independência entre si quanto as páginas do romance mais tradicional o fazem: quase nenhuma. É possível ler uma página do Wake e dar-se por satisfeito tanto quanto é possível ler uma página de qualquer livro e saber que aquilo é apenas uma amostra, um pedaço, uma parte separada do todo que the confere coerência como obra.

As duas primeiras formas de leitura, portanto, parecem-nos similares. No entanto, acessar uma obra a partir de uma página ou a partir de outra página, ainda que seja uma obra circular, isto é, sem início, meio e fim definidos, resulta em duas leituras absolutamente diferentes. No entanto, aqui tem-se a diferença crucial entre o Wake e qualquer outro livro: uma estrutura circular implica, necessariamente, na diluição do segmento temporal fechado, isto é, numa abertura em que qualquer página do livro pode ser parte de um início, de um 
meio ou de um fim. Afinal, o livro pode ser livre dessas divisões em sua estrutura, mas o tempo da leitura jamais será. Sempre temos de ler em alguma ordem, e algum trecho inicia esse processo, algum se faz no meio e algum trecho conclui nosso percurso como leitores. Caso pensemos, portanto, em multiplicar as possibilidades de acesso ao Finnegans wake até que sejam consideradas todas as possibilidades de leitura, teríamos de lidar com nada menos que seiscentas e vinte e oito formas de acesso à obra, no mínimo.

Mostra-se impossível, é evidente, experimentar todas essas formas de acesso. Considerando que houvesse o tempo necessário, deveríamos levar em conta, ainda, a contaminação inevitável no processo; isto é, a certo ponto, já se saberia o que esperar e a mudança na ordem não teria o mesmo efeito que teria se acessada em uma primeira leitura. Uma vez lido em uma certa ordem, o livro jamais será redescoberto através de outra, ao menos não como se nunca tivesse sido lindo anteriormente, qualquer que seja a nova ordem.

O que nos é possível questionar é até que ponto essa circularidade existe de fato, tentando expor não apenas a forma como ela é concebida e a partir de que modelos, mas também as consequências de seu uso e se a circularidade se dá apenas idealmente ou se é, de fato, executada, isto é, temos de investigar se é perceptível e constatável considerando o acesso ao livro por qualquer uma de suas páginas. O que origina a elaboração dessa estrutura em Finnegans wake é, como se sabe, "Vico's recurrent cycle, at once repetitious and various — like the Wake itself" e Tindall nos chama a atenção, ainda, para o fato de que "Joyce's hieroglyph for the Wake and its title is a square, its sides, no doubt, the quadrants, a little squashed, of Vico's wheel"28 (TINDALL, 1969, p. 10). Mesmo que a forma geométrica escolhida por Joyce em seus desenhos na elaboração do Wake tenha sido não o círculo, mas o quadrado, isso se explica pela escolha por quatro partes e ainda assim se relaciona à circularidade viconiana. Nesse caso, a forma geométrica ter vértices ou não é irrelevante - Joyce chega a preferir um cubo,

\footnotetext{
28 "O ciclo recorrente de Vico, concomitantemente repetitivo e variado - como o próprio Wake" e "o hieróglifo de Joyce para o Wake e seu título é um quadrado, ainda que seus lados, sem dúvidas, são os quadrantes, um pouco distorcidos, da da roda de Vico."
} 
em alguns momentos —, uma vez que se poderia observar uma espécie de "circularidade" também nessas outras formas ao circundá-las, especialmente enfatizando um perímetro percorrido em repetição cíclica que retorna a um ponto.

A ideia desse retorno a um ponto é outro problema basilar derivado da aceitação do princípio da circularidade de Finnegans wake. Deve-se lembrar que nem o ricorso de Vico, nem a circularidade da obra de Joyce resultam no retorno ao mesmo ponto, pois em ambos os casos o ponto original é irrecuperável. Depois de ler todas as sentenças de Finnegans wake, a continuação da última frase (dizendo aqui "última", é claro, deixando de lado a relativização da ordem que acabamos de engendrar e tomando, portanto, a ordem linear numérica) retorna ao mesmo ponto se pensarmos que retorna à página 1; essa página, no entanto, já não é mais a mesma que se tinha quando se iniciou a leitura. Assim se dá, também, com o ciclo das idades proposto por Vico, que serviu como modelo para o Wake: após o fim da Idade dos Deuses, dos Heróis e dos Homens, há um ricorso à Idade dos Deuses - no entanto, é outra Idade dos Deuses que está se formando, com aspectos gerais que a definem, mas que não está retrocedendo a uma mera repetição. Não se tem uma máquina do tempo que vai e vem, atravessando as mesmas fases, mas uma evolução que evoca circularidades heterogêneas. Uma figura recorrente é a do eco, que remete ao movimento de repetição cíclica e é executado tanto na sonoridade do próprio texto, com rimas e aliterações/assonâncias, quanto também, por vezes, citado explicitamente: "The echo is where in the back of the wodes; callhim forth!" (FW, 126.3) ${ }^{29}$. O formato circular que não supõe repetição é perceptível em outras obras de Joyce. Em Retrato, Stephen frequentemente se apresenta preso em linhas de raciocínio que parecem recair sobre si mesmas ou sobre um ponto originário, mas que engendram, ainda assim, deslocamento. Mesmo em Ulysses, há evidentes formas de circularidade, a começar pela jornada diária do protagonista Leopold Bloom, mas que não insinua dias sempre iguais, até a estrutura do monólogo de Molly, que reitera termos à medida que avança.

${ }^{29} \mathrm{Na}$ tradução de Donaldo Schüler: "O eco é onde no fundo da florode; que venha!". 
Apesar de a estruturação circular ser aceita a priori por William York Tindall como a base de Finnegans wake, o estudioso estadunidense não parece considerar, de fato, as implicações desse círculo, tomando apenas as suas causas ou origens, mas não as consequências de afirmação dessa estrutura. Tindall afirma que o primeiro capítulo é visivelmente uma introdução geral e o último, uma conclusão com o diferencial de que abarca, ainda, a função de atiçar o leitor para ao retorno à primeira página. Vemos, então, o problema lógico em sua afirmação: se o trecho "final" de Wake serve para levar o leitor ao fragmento de número 1, temos um trecho incumbido de algo que se parece com uma espécie de introdução a esse retorno, ou que, certamente, tem alguma função muito distinta da de concluir. York Tindall, provavelmente entrevendo a incoerência no que afirma, explica: "A general conclusion [the last chapter] and a general introduction [the first one], parallel in function, demand parallel methods"30 (TINDALL, 1969, p. 305).

No entanto, o que Tindall afirma haver de similar entre o primeiro e o último capítulos existe por todo o livro. Há sequências de retornos - no capítulo 4, depois no oitavo e assim por diante. O mesmo vale para as três idades, que formam, com o ricorso, os quatro lados desse percurso, que não se repetem, mas reaparecem distintos, ainda que apareçam em ordem sempre esperada, isto é, estejam alocados em trechos previsíveis, devidamente selecionados para eles dentro da grande ordem de todas as fases. $O$ acesso, então, a depender de que fragmento servirá como o início, pode se dar em um fragmento elaborado nos moldes da Idade dos Deuses, dos Heróis ou dos Homens, ou, ainda, do ricorso, mas será sucedido de uma ordem invariável. Que haverá diferenças entre uma leitura que se inicie em um capítulo, escrito de uma forma, dentro de certa estrutura basilar, e uma que se inicie por outro, que tenha outra estrutura, não há dúvidas; se a leitura do todo do livro for possível de todos os fragmentos, porém, a circularidade estará comprovada. O livro que se lê, então, tem de ser o mesmo, somente acessado em outra ordem e, portanto, a partir de uma

\footnotetext{
30 "Uma conclusão geral [o último capítulo] e uma introdução geral [o primeiro], paralelas em
} função, demandam paralelismo em método." 
sequência distinta de leitura, mas que permita concluir a leitura assim como a tentativa que começa do fragmento 1 também propicia.

A figura espectral se mostra deveras pertinente: Wake se diferencia também pela formação de uma polifonia especial, que nos confunde não apenas em termos de não saber que personagem está falando agora?, mas ainda de trazer as vozes dos mortos para se misturarem às dos vivos, sem que se intercalem, mas efetivamente convivam - o que também exige uma compreensão temporal absolutamente única, em que, em meio ainda a possibilidades de porvir, não há separação espaço-temporal entre um suposto agora e um suposto antes. No livro James Joyce and the difference of language, Laurent Milesi diz:

This evolution is thus inseparable from an increasing dissolution or, ar leat, problematization of neat entities like character and voice, as well as the boundaries between them, and, consequently, from the emergence of more polyphonic voices which, in the 'pollylogue' (FW, 470.9 ) or 'drama parapolylogic' (FW, 474.5) of Finnegans wake, will ultimately combine with shifting enunciative poles and a pliable linguistic medium to create erring discursive effects ascribable to a 'side' or 'role' ina many-faceted 'character complex'. (MILESI, 2003, p. $91)^{31}$

A estrutura circular e a referência a figuras de diversos momentos históricos, bem como a livros como o Livro dos mortos egípcio ou o Livro de Kells irlandês, unem-se na dissolução de fronteiras temporais: Finnegans wake, certamente, não tem nem poderia pretender ter um momento (mesmo externo, histórico) definido, nem mesmo um tempo psicológico definido - que assumiria a perspectiva da consciência de uma personagem como sobressalente, ditando voz, perspectiva, contexto.

\footnotetext{
31 "Essa evolução é então inseparável da crescente dissolução ou, ao menos, problematização de entidades precisas como personagem e voz, bem como das fronteiras entre elas, e consequentemente, da emergência de mais vozes polifônicas que, no 'pollylogue' (FW 470.9 ou 'drama parapolylogic' (FW 474.5) de Finnegans wake, vão por fim combinar com pólos enunciativos instáveis e um meio linguístico elástico para criar efeitos discursivos errantes atribuíveis a uma 'fronteira' ou 'papel' em um mil-faces 'complexo de personagem'."
} 
Faz-se espectro, ainda, o todo da obra literária na medida em que não se sabe como ela será executada pelo leitor que se depara com ela. Como uma partitura sem indicações precisas, trazendo meras sugestões e portanto inúmeras possibilidades de trocas, Wake precisa ser executado, mas pode sê-lo de diversas maneiras, em diversas ordens. Assim, não se tem uma imagem nítida do que é o Finnegans wake, mas, primordialmente, sabe-se o que ele pode vir a ser, em mais de uma possibilidade.

A isso, como já foi exposto, está ligada uma temporalidade que poderá operar diferentemente em cada execução da partitura wakiana. Uma oposição entre o tempo linear e o tempo cíclico pode mostrar como a estrutura basilar do Wake, que se afasta da linearidade, possibilita essa diversidade e o que isso pode significar na tessitura textual e para uma leitura atenta ao escritural do texto. Explicando a diferença entre tempo cíclico e tempo linear, o filósofo Karl Jaspers (1883-1969) diz:

\begin{abstract}
O ciclo do tempo, visto como recorrência, é a imortalidade do que em tal ciclo se produz. (...) A todo instante, está ligando o fim ao começo. Vive no ciclo do eterno retorno. Pode ocorrer que a distância a separar o fim (morte) do começo (novo nascimento) seja imensa, mas reduzse a nada se a vida é revivida de maneira infinitamente repetitiva, fazendo-se, em tal sentido, imortal. (...) Inteiramente diverso é o que se passa com o tempo linear. Tudo que é temporal é levado pelo tempo linear a um fim irremediável. (JASPERS, 2011, p. 146).
\end{abstract}

A estrutura circular de Finnegans wake faz mais do que nos prender ao livro-sem-fim: traduz uma possibilidade de existência fora do andamento do tempo, na pura temporalidade, isto é, naquilo que não ultrapassa um presente, mas permanece nele. Obriga-nos a estar no presente da leitura sem nos desviarmos e sem conclusão: relendo e relendo e relendo. Joyce nos obriga, mantendo-nos na atividade da leitura que nunca termina, a cumprir a exigência que faz ao seu leitor. Instalando o texto num eterno retorno, transforma-se nessa afirmação da vida, em que a morte já não ocupa o espaço do esquecimento: a voz dos mortos ecoa entre os vivos, sua presença faz-se material; a morte, de certa maneira, aí já não existe. 
O tempo absoluto da concepção cíclica, que não pode ser transposto, se opõe ao tempo linear em que há resolução, transposição: um acontecimento ultrapassa o outro, um momento sucede o seguinte. $O$ apagamento do que fica no passado só pode ser modificado pela solução de decidir o que se grava na história. Mesmo assim, não se recupera nada por inteiro, sendo impossível uma volta ao passado: a memória evoca as reminiscências, que ocupam o tempo presente apenas como resto incorpóreo, como espectro. O tempo absoluto se faz de maneira inteiramente distinta. Nas palavras de Jaspers, nele "faz-se aquilo que se repete infinitamente - e permanece temporal. (...) Tempo linear e tempo cíclico são enigmas incompatíveis. (...) O tempo cíclico torna possível a ideia do 'uma vez mais' por meio do eterno retorno" (Ibid., p. 147).

O tempo cíclico do retorno também se faz em espectros: o retorno é sempre o "uma vez mais", porém sempre singular, jamais uma repetição idêntica, senão recairia em uma simples hipotética volta ao passado do tempo cronológico, como uma espécie de máquina do tempo construída no tempo linear. O retorno do tempo cíclico não se faz dessa maneira; é um novo acontecimento, mas que se relaciona com algo já ocorrido. Se lermos o Wake circularmente, isto é, repetidamente, obedecendo à continuação do último fragmento no primeiro, não estaremos rebobinando nosso tempo, mas tão somente fazendo uma nova leitura de uma mesma coisa, um mesmo texto que não se alterou enquanto não estávamos olhando. Há, assim, uma diferença, um assombro do que se leu antes percorrendo o momento da releitura. O tempo cíclico se faz, então, no seu retorno eterno, de fantasmas.

A palavra retorno, no português, talvez não seja tão adequada, justamente por apagar essa diferença: "retornar" pressupõe que se foi a algum lugar ao qual se está voltando; indica, então, mais imediatamente, o movimento do tempo linear, de maneira que se imagine uma volta na linha do tempo ao tempo passado estanque em seu lugar. No entanto, ricorso, termo de Giambattista Vico, se relaciona a curso, àquilo que flui, parecendo então mais adequado à ideia do tempo cíclico em que as repetições são novos acontecimentos. Justifica-se aqui a expressão criada para intitular este trabalho, que conjuga "fluir" e "ricorso" para explicitar esse caráter no termo italiano de Vico. 
A maneira como esse engendramento cíclico foi relido, na filosofia moderna, com o eterno retorno de Friedrich Nietzsche, indica ainda a positividade dessa estrutura. Como o fim de Ulysses é o "sim" - e Joyce queria que assim ele se mantivesse mesmo traduzido, como a correspondência a respeito da tradução para o francês comprova, em que Joyce pede para que 0 fim seja tão somente a palavra "sim" - , o ciclo cósmico reafirma o sim para o mundo, o cada vez novamente, o novo déjà. É a ação que não se direciona a uma finalização, não tende ao término, mas à atividade plena contínua. "O mundo afirma-se por si também na sua uniformidade que permanece a mesma no decurso dos anos, bendiz-se por si mesmo, porque é aquilo que deve voltar eternamente, porque é o devir que não conhece saciedade, tédio, nem fadiga" (Wille zur Macht, ed. 1901, § 385).

A entrada na narrativa de Finnegans wake, isto é, o contato inaugural do leitor com os acontecimentos narrativos, é anunciada por uma queda: "The fall: bababadalgharaghtakamminarronnkonnbronntonnerronntuonnthunntrovarrhoun awnskawntoohoohoordenenthurnuk!“. Queda reverberante, com repetições silábicas misturadas e a formação desse conjunto de fonemas que não é verbete em nenhum idioma, mas comporta idiomas diversos; não é um ponto de partida da narrativa - não há um primeiro acontecimento ou ação - , mas a queda na narrativa que já está em curso, como uma queda d'água anunciada no riverrun, a palavra de abertura da obra. Assim, a narrativa inicia-se já iniciada.

Após o riverrun, diz-se: "past Eve and Adam's". Pode-se ler tendo em mente que estamos passando em frente a Eve and Adam's, catedral em Dublin, ou que aquilo que será narrado se situa temporalmente após Adão e Eva, ou mesmo no passado do casal primário, em tempos inefáveis. O tempo é fluido, talvez aparentemente caótico, mas apenas repensado, reimaginado mudanças de parâmetros que pedem uma revisão radical. Isso também podemos dissecar no título, que comporta o fim (fin, no francês, e finis, no latim) e a sua repetição (-egan, again — o próprio eterno retorno), ou o fim de encontro ao despertar (fin-egans: (la) fin against + (the) Wake, relacionando também ao nome do personagem Earwicker, que em alemão é erwecker, "aquele que desperta"), ou ainda contra outro fim: o velório, outra tradução para wake, 
substantivo. Como aponta Donaldo Schüler, "A circularidade viconiana gira no geral e nos detalhes" (SCHÜLER, 2004, p. 17).

Para William York Tindall, o tempo é a mais importante matéria desse "ensaio sobre o homem" de James Joyce: "Rise and fall and rise again, sleeping and waking, death and ressurrection, sin and redemption, conflict and appeasement, and, above all, time itself - saecula saeculorum - are the matter of Joyce's essay on man"32 (TINDALL, 1969, p. 4). Também caracteriza a obra como a comédia humana de Joyce: "Not only his essay on man, the Wake is his human comedy"33 (Ibid., p. 7). Ao final de sua introdução, Tindall afirma que seu livro não visa a uma apreensão completa nem a ultimatos sobre a obra, mas sim a ser um suplemento dos estudos prévios: "After all, what authority on the Wake knows half of it? Which half is the critical question"34 (Ibid., pp. 25-26).

O tempo em Finnegans wake, destacado por Tindall, cumpre papel vital em toda a organização da obra, além da estrutura circular em quatro partes que Joyce emprega livremente das Idades do filósofo Giambattista Vico — assim como a Odisseia de Homero serve de base para Ulysses, o Wake tem correspondente; nesse último caso, no entanto, Joyce parte de fonte filosófica em vez de literária. Ainda no início, quando Harriet Weaver pareceu não entender e não gostar do que leu do Work in progress, Joyce "insistiu com ela para que lesse a Scienza Nuova de Vico, como, com o Ulisses, insistira em que lesse a Odisseia" (ELLMANN, 1989, p. 695). Não é só no cerne estrutural, porém, que podemos perceber a especificidade do tempo de um romancepoema plotless que, se não possui enredo, não possui, portanto, linha cronológica explícita. Tindall pretende e tende a extrair o plot, concatenando as cenas sempre com uma possível visão de causa e consequência, pontuando as personagens, nomeando-as e definindo-as. Eventualmente sua tentativa recai, contudo, na incontornável indefinição.

\footnotetext{
32 "Ascender e cair e ascender novamente, dormir e despertar, morte e ressureição, pecado e redenção, conflito e conciliação, e, acima de tudo, o próprio tempo - saecula saeculorum — são a matéria do ensaio de Joyce sobre o homem."

33 "Não apenas seu ensaio sobre o ser humano, o Wake é sua comédia humana."

34 "Afinal de contas, que autoridade no Wake sabe metade do que se tem a saber sobre ele? Qual metade é a pergunta fundamental."
} 
Percebemos a dificuldade no exemplo do segundo capítulo, que é um dos mais claros em termos de composição de cena ou, ao menos, quanto ao desenrolar das ações e seus agentes, o que Tindall atribui ao fato de ter sido um dos primeiros que Joyce escreveu: "Maybe he did not have time, going over it, to complicate it, according to his habit"35 (Ibid., p. 57). Quanto a tempo e espaço, contudo, permanecemos na pluralidade - ou, mais pertinente dizer, na ubiquidade. Tomemos um entendimento primário da cena, com o qual poderíamos depreender o enredo geral: temos Earwicker (a essa altura, já tivemos esclarecimentos sobre sua alcunha) no Phoenix Park, em Dublin, surpreendido por um jovem que the pergunta as horas. O garoto portava um cilindro, o que pode justificar que Earwicker (aqui lembramos Wecker, alemão para despertador - aquilo que dá as horas) se sentiu ameaçado. Defende-se, demonstrando culpa, e não responde com a precisão que a pergunta demandaria. O deslocamento no tempo e no espaço, porém, ocorre em diversos pontos: no paralelo de Earwicker com Adão, na culpa em comum por terem cometido algum pecado - Adão, no Jardim do Éden; nosso protagonista, no parque em questão.

\begin{abstract}
They tell the story (an amalgam as absorbing as calzium chloereydes and hydrophobe sponges could make it) how one happygogusty Idesof-April morning (the anniversary, as it fell out, of his first assumption of his mirthday suit and rights in appurtenance to the confusioning of human races) ages and ages after the alleged misdemeanour when the tried friend of all creation, tigerwood roadstaff to his stay, was billowing across the wide expanse o four greatest park in his caoutchouc kepi and great belt and hideinsacks and his blaufunx fustian and ironsides jackboots and Bhagafat gaiters and his rubberised inverness, he met a cad with a pipe. (FW, 35.1-11) $)^{36}$
\end{abstract}

\footnotetext{
35 "Talvez ele não tenha tido tempo, ao percorrê-lo [o texto], de complicá-lo como de hábito."

${ }^{36} \mathrm{Na}$ tradução de Donaldo Schüler (2000): "Contam a estória (uma amálgama tão absorvente quanto cálcio clorado e esponja hidrófoba poderiam performá-la) como numa letagostosa idosde-abril manhã (o aniversário, como se soube, da primeira assunção do nascimento, costumes e direitos em pertinência à confusão das raças humanas) idades e idades após a alegada delonga quando o amigo comprovado de toda criação, begala de pau-marfim para seu equilíbrio, ondulava através do vasto território do nosso mais esplêndido parque com seu kepi caucho e imenso cinturão, cota de ferro, humor fásutico, botas de cavalaria inglesa, espirituralidade hindu e c apa de chuva, ele encontrou um cadete com um cilindro."
} 
Tindall abre a possibilidade de a cena se ampliar e se desdobrar no espaço e no tempo, relacionando a cena ao pecado original: "Maybe it is any sin of every man or every sin of any man"37 (TINDALL, 1969, p.58). O que Earwicker fez de errado, no entanto, permanece em suspenso para o leitor, em meio aos tantos boatos que se reproduzem, aparentemente, de maneira incessante. Aparecem, ainda, outros paralelos espaço-temporais, como aparece na expressão "Ides-of-April morning", que lembra os Idos de Março (o dia 15 desse mês, data do assassinato de Júlio César). O jovem vai embora e os rumores se desdobram cada vez mais, fazendo de Earwicker desde um homem que se sente abstratamente culpado até um réu efetivo de um crime indefinido.

Chamar essas referências de "paralelos", no entanto, como faz Tindall, pode ser uma forma de suprimir a função delas na amálgama (an amalgam as absorbing as calzium chloereydes and hydrophobe sponges could make it) do texto. Uma cena simples, como a supracitada, que parece poder ser posta com clareza e ter seus elementos narrativos devidamente pontuados, desdobra-se em ambiguidades e referências a outros tempos e espaços que não são externos e comparados a ela, mas que a compõem tanto quanto os fatos que apresentamos como primários: o culpado Earwicker, ou HCE, está no Phoenix Park, mas ele é também Adão no Éden (e não está no primeiro parque assim como Adão esteve um dia no Éden). Está em Roma e é também vítima de conspiração, assassinado por Brutus. Finnegans wake trata, como afirma Tindall, da humanidade, do universal, mas em acontecimentos vividos por indivíduos, em suas realidades microscópicas, como um enredo que se desfaz em meio a numerosas e esparsas superposições: assim se forma a amálgama wakiana.

Após ser julgado, Earwicker é preso e, posteriormente, morto. Tindall, contrariamente a suas pretensões de sumarizar o enredo e determinar a ordenação dos acontecimentos, novamente não pode evitar alguma hesitação ao tentar descrever os ocorridos do capítulo IV: "Earwicker dead? Anyhow, they took the liberty of burying him" (Ibid., p. 85). Assim, notamos que, por mais que

37 Tradução nossa: "Talvez seja qualquer pecado de todo homem ou todo pecado de qualquer homem." 
se tente concatenar as cenas, não se pode fazê-lo sem interrogações, parênteses, bifurcações, multiplicações. A dúvida quanto à morte da personagem vem pelo motivo de que simplesmente não temos a morte factual - como ocorreu, onde, se foi homicídio -, assim como o delito de Earwicker se apaga ao se multiplicar: são tantas as conjecturas que nem se pode mais lidar com o fato. Além disso, Earwicker continua presente na narrativa, mesmo finado. Não temos o acontecimento concreto de sua morte seguido pelo relato de como seguiram as outras personagens; em vez disso, temos referências aos que compareceram ou não a seu enterro, à tumba, ao processo de sepultamento no rio e outras evidências de que ele estaria morto, tudo enquanto o morto permanece ali, não como assombração, mas duplicado entre os presentes e os ausentes.

Com essa dúvida, então, a questão do tempo novamente se coloca: como pode haver a vivência da morte, tão essencialmente temporal - marco cronológico do fim, vivência humana de uma temporalidade do luto —, sem sua determinação? A hesitação na afirmação da morte da personagem anula que se possa viver sua ausência e, portanto, o luto. Isso engendra não somente mais uma quebra na narrativa, mas ainda uma dinâmica própria do processo de perda. Assim como observamos na cena do Phoenix Park, o que ocorre não é uma divisão do enredo em duas realidades paralelas, ou dois enredos paralelos, em que um contempla a morte e o outro lida com a vida, mas de uma só situação.

Se a morte não é fato pontual, fechado, uníssono do enredo, o trabalho do luto não terá uma origem propriamente estabelecida — ou, tendo como origem uma perda que se fez em presença e em ausência simultaneamente, terá uma outra formação e dinâmica. A narrativa, então, não terá suas implicações de consequência, uma vez que a causa não é certa. Se tomarmos, para pensar o luto, a exposição de Sigmund Freud em Trauer und Melancholie, de 1915, em que o luto e a melancolia são comparados a partir do "quadro geral desses dois estados" (FREUD, 2010, p. 128), de forma que ambos os quadros se aproximam em todas as descrições clínicas e se diferenciam apenas pela afetação da autoestima, teremos a seguinte definição do luto: 
Via de regra, luto é a reação à perda de uma pessoa amada ou de uma abstração que ocupa seu lugar, como pátria, liberdade, um ideal etc. (...) Confiamos que será superado após certo tempo, e achamos que perturbá-lo é inapropriado, até mesmo prejudicial. (...) O luto profundo, a reação à perda de um ente amado, comporta o mesmo doloroso abatimento, a perda de interesse pelo mundo externo - na medida em que não lembra o falecido -, a perda da capacidade de eleger um novo objeto de amor - o que significaria substituir o pranteado -, o afastamento de toda atividade que não se ligue à memória do falecido. (Ibid., pp. 128-129)

Ora, se a personagem é enterrada, mas não é de todo perdida, não se vai por completo do plano onde estão as personagens vivas, como estabelecer a perda, que se tem como premissa imprescindível do luto? A perda engendra 0 que Freud chama de trabalho do luto: toda a libido relacionada ao objeto perdido precisa ser redirecionada, mas a resistência ao abandono dessa libido é desconfortável, podendo gerar até distanciamento da realidade - muito dura para se suportar - e psicose de desejo. Todo esse processo, porém, tem um resultado: "Mas o fato é que, após a consumação do luto, o Eu fica novamente livre e desimpedido" (Ibid., p. 130).

De toda a explanação de Freud a respeito do luto, não podemos deixar de concluir que seu tempo - e, ao que tudo indica, também o da melancolia - é alterado. Com a perda desestabilizadora, o indivíduo se vê imerso na necessidade de uma mudança de parâmetros para seu conforto habitual, na busca pela substituição do ente perdido e no caminho de redirecionamento da libido cuja origem se perdeu. Assim, seria seguro dizer que o trabalho do luto racionalizado por Freud pressupõe um tempo de luto, diferenciado do tempo normal da vida. No Wake, o texto ressoa esse trabalho de luto e seu tempo próprio, o remordimento da morte e do morto em meio a descrições que abarcam homenagens, seu enterro e seu descanso:

Any number of conservative public bodies, through a number of select and other committees having power to add to their number, before voting themselves and himself, town, port and garrison, by a fit and proper resolution, following a koorts order of the groundwet, once for all out of plotty existence, as a forescut, so you maateskippey might to you cuttirunner on a new pack of klerds, made him, while his body still persisted, their present of a protem grave in Moyelta of the best Lough 
Neagh pattern, then as much in demand among misonesans as the Isle of Man today among limniphobes. Wacht even! It was in a fairly fishy kettlekerry, after the Fianna's foreman had taken his handful enriched with ancient woods and dear dutchy deep-linns mid which were na old knoll and a troutbeck, vainyvain of her osiery and a chatty sally with any Wilt or Walt who would ongle her as Izaak did to the tickle of his rod and watch her waters of her sillying waters of and there now brown peater arripple (may their guilt lightly over his somnolulutent form!). Whoforyou lies his last, by the wrath of Bog, like the erst curst Hun in the bed of his treubleu Donawhu. $(\mathrm{FW}, 76.14)^{38}$

Poderíamos compreender muito a respeito dessa morte no Wake partindo apenas do fato de que o trecho do capítulo IV em que se anuncia o enterro subaquático da personagem Humphrey Chimpden Earwicker parodia os textos egípcios que chamamos de forma abrangente de Livro dos Mortos, coletivo do que era registrado sobre as tumbas para auxiliar os defuntos em seus caminhos pós-morte, sem distinção de nobreza, mas que envolviam julgamentos morais de merecimento e davam diversas orientações para a superação de obstáculos que porventura surgiriam para o morto nessa transição. Esses escritos eram chamados pelos egípcios de "textos para ir/voltar à luz", o que já nos indica que haveria um caminho a ser traçado por Humphrey, de maneira que a sua morte, experiência mais radical de finalização, não seria, para ele, o ponto final do percurso. Em vez de seguir para "o além" ou para o mundo dos mortos, muito ao contrário, o morto submerso segue para a luz que há na superfície, em um caminho de volta à vida. A passagem não é encarada como uma superação de barreiras ou uma peripécia narrativa surpreendente; ao invés disso, tem-se, na verdades, quase uma ausência de barreiras entre os dois aspectos da existência.

\footnotetext{
38 Como traduziu Donaldo Schüler (2000): "Qualquer número de corpos públicos conservadores, através de um número de seletos de outros comitês com poder de adicionar a seu número, antes de votar em si mesmos e nele, urbe, porto e guarnição, por adequada e própria resolução seguindo uma ordem judicial da constituição, uma vez por todas fora de existência narrativa, como um pitoco, assim podes cortar tudo o que te incomoda num novo baralho de panos, quanto a ele, enquanto seu corpo ainda persistiu, presente deles, um sepulcro pro tempore na planície de Moryelta do melhor modelo dos defuntos sob o Lough Neagh, então tão em demanda entre os misonésios quanto a llha de Man agora entre os limnófobos. Un momentito! Foi em fabulosa caça piscosa, depois ki Finn pró-homem tinharrancado um punhado de turfa, enriquecido com bosques antigos e bem postos pantanos dos baixos países nos quais havia picos e bicos de truta, vivamente vaidosos de suas ramadas e dos salgueiros no bleblablá de Blá a Blé que iria fisga-la como fez Izaak para excitar sua raiz e contemplar suas águas de suas indefesas águas e agora os brunos arrepios de sua pele pedrosa (queira seu vestido vestir levemente sua sonululante forma!) Queporti jaz no seu derradeiro jazigo, pela rabia de Diós, como o remoto réprobo Huno, no leito azul de seu Tunobiasal".
} 
No capítulo referente ao enterro e posterior ressurreição de Humphrey Chimpden Earwicker, as intrusões em referências ao tempo e a temporalidade são numerosas:

Best. This wastohavebeen underground heaven, or mole's paradise which is probably also an inversion of a phallopharos (FW, 76.33-34) $)^{39}$

all differing as clocks from keys since nobody appeared to have the same time of beard, some saying by their Oorlog it was Sygstryggs to nine, more holding with the Ryan vogt it was Dane to pfife. (FW, 77.11$14)^{40}$

But abide Zeit's sumonserving, rise afterfall. $(\mathrm{FW}, 78.7)^{41}$.

As tantas alusões indicam como formas ou visões do tempo permeiam tudo o que está sendo narrado, mas vemos que não há indicações precisas: falase repetidamente do tempo sem, no entanto, estabelecer marcos cronológicos, divisões concretas ou definições temporais para a narrativa. Se o tempo no Wake não é vetorial e nem busca medições, também não pode sê-lo na morte ou no luto, por mais marcados e marcantes que esses eventos fossem em outras realidades. No lugar do sonho, tudo muda, até mesmo as mais radicais ocorrências: presenças são etéreas, espectros convivem, cenas e marcos se dissolvem.

O tempo dissolvido nas multiplicidades, em vez de apreendido e entendido linearmente, corrobora o que dissemos a respeito da impossibilidade de escolher uma linha enredística em detrimento de outra, ao menos sem que isso fira a tessitura conjunta que a diversidade espaço-temporal oferece. Assim como estamos em diversos tempos e (em um parque de Dublin, na Roma antiga,

\footnotetext{
39 Também segundo a tradução de Donaldo Schüler (2000): "Bem. Este subterrâneo foi-parahaver-de-ser céu ou o paraíso dos molhes que provavelmente foi também uma inversão de um phallofarol (...)".

40 Idem: "diferindo tudo como sinos diferem de chaves visto que ninguém parecia ter o mesmo horário à barba, alguns queriam por seu Horlógio que era Sixtriques pras nove, outros apegados à Ira Landa diziam que era Dane-se para as cinco".

41 Idem: "Mas aguardemos o requerimento do tempo, despertar após-queda".
} 
no Éden e assim por diante), tudo ocorre ao mesmo tempo (o pecado de Adão é o de HCE e seu sentimento de conspiração, que culmina em assassinato, é o mesmo de Júlio César). Temos todo o texto como o tropo. Não havendo escolha de linha cronológica ou de espaço, não há ação pontual que se possa eleger.

Em um nível mais microscópico do texto wakiano, o mesmo acontece no que concerne aos tão numerosos neologismos. Não há como escolher um significado ou outro: são simultâneos e quase sempre autorreferenciais. Poderíamos então compreender a fama de ilegibilidade: se a leitura deve considerar que tudo é deslocado e que nada se consolida sem grandes perdas, é válido ver tamanha dificuldade em Finnegans wake. É exigido do leitor que diversos textos em um sejam lidos - portanto, ler os diversos textos sem separálos. Em Derridabase, Geoffrey Bennington discorre, com o pensamento de Jacques Derrida, a respeito do entendimento de significante e de significado, partindo da noção de signo estabelecida por Ferdinand de Saussure:

\begin{abstract}
No sistema de diferenças que é a língua, todo significante funciona remetendo a outros significantes, sem que se chegue nunca a um significado. Procurem no dicionário o significado de um significante desconhecido, vocês encontrarão outros significantes, nunca significados. Já foi dito, um significado não é mais do que um significante posto numa certa posição por outros significantes: não existe significado ou sentido, só há 'efeitos' (Positions, p. 90). Mas este privilégio concedido ao significante logo o destrói: com efeito, o significante 'significante' só significa na sua relação com (o significante) 'significado', que ele coloca de antemão em posição de prioridade. 'Significante' e 'significado' se entreimplicam, assim como eles implicam 'signo' e 'referente'. É impossível para nós estipular (conforme um gesto que é, às vezes, o da filosofia analítica) que 'significante' daqui pra frente não implicará 'significado' como seu corolário, sob pena, como Humpty Dumpty, de cair na ilusão do convencionalismo, e de esquecer que recebemos a língua e suas sedimentações muito mais do que as criamos. (BENNINGTON, 1996, p. 34)
\end{abstract}

Assim, podemos compreender também que em Finnegans wake existam "efeitos de significado" em vez de categorias sólidas a que pudéssemos recorrer para a compreensão do signo. Talvez fique claro como um dicionário com significados estanques dos termos da obra literária seria tão ou ainda mais 
parcial do que os dicionários comuns a que Bennington se refere. Os efeitos são, portanto, aquilo que operam como fantasmas, espectros que rondam a materialidade do texto. Esses espectros não apenas perpassam alguns momentos, mas efetivamente habitam a tessitura textual.

O filósofo franco-argelino Jacques Derrida, rompendo com uma concepção de tempo exposta na obra do fenomenólogo alemão Edmund Husserl, ultrapassa a noção tanto espacial quanto temporal de um percorrer regido unidirecionalmente, bem como substitui essa dada noção circular ou cíclica, que perigosamente remete ao risco de uma redundância, por uma ideia de elipse, em que nunca se alcança verdadeiramente o objeto nem se recupera as condições prévias do caminho percorrido. O movimento elíptico pode ser aqui invocado não para substituir a ideia do círculo que aparece em James Joyce, uma vez consideradas todas as nuances dessa circularidade aqui expostas, mas para acrescentar uma espécie de nuance elíptica dessa circularidade que não produz redundância ou repetição, mas singularidade e mesmo inovação. Tendo seu centro deslocado, um trecho percorrido na leitura impede terminantemente que o passado da leitura seja revisitado da forma como foi lido em seu presente irrecuperável.

Citado por Joanna Hodge em Derrida on time, Jacques Derrida, em seu ensaio "Form and meaning: a note on the phenomenology of language", datado de 1967, propõe um pensamento que poderia valer para o Finnegans wake, ao menos dentro da discussão aqui proposta, a respeito do formato estrutural da obra final de James Joyce. A respeito do que não poderia ser apreensível por uma dialética per se - algo que, veremos, distancia-se daquilo que conjectura o escritor irlandês em suas obras —, diz Jacques Derrida:

Thus one does not have to choose between two lines of thought. Rather, one has to meditate upon the circularity which makes them pass into one another indefinitely. And also by rigorously repeating this circle in its proper historical possibility, perhaps to let some elliptical displacement be produced in the difference of repetition, a deficient displacement doubtless, but deficient in a way that is not yet --- or is no longer --- absence, negativity, non-Being, lack, silence. Neither matter 
nor form, nothing that could be recast by some philosopheme, that is, by some dialectics, in whatever sense dialectics may be determined. An ellipsis both of meaning and of form: neither full speech, nor a perfect circle. More a less, neither more nor less. Perhaps an entirely other question. (DERRIDA apud HODGE, 2007, p. 11) ${ }^{42}$

A descrição do percurso elíptico em Derrida acrescenta, aqui, ao princípio de não redundância, como supracitado quanto à circularidade de Finnegans wake. No entanto, uma espécie de dialética ocupa as preocupações do escritor irlandês. Joyce foi influenciado pela ideia de atração de contrários exposta no The Marriage of Heaven and Hell, do inglês William Blake, e da antecipação da dialética hegeliana de Giordano Bruno de Nola, filósofo italiano, em que "all is in all", como em Finnegans wake.

Desde uma de suas primeiras publicações, Gramatologia, Jacques Derrida aponta uma espécie de condescendência - ou, como ele diz, solidariedade - entre uma concepção histórico-metafísica calcada no linear, portanto calcada na estruturação de presente após presente, tempo após tempo, em que há sequências e possíveis inícios, meios e fins, com um modelo discursivo tradicional, épico. Denuncia igualmente que "a 'linha' representa apenas um modelo particular" (DERRIDA, 2011, p. 107) e que esse modelo, por mais que tenha marcado uma norma imperante, não prescinde do conceito mundano da temporalidade - o conceito de homogeneidade e continuidade, seja reto, seja circular, que Heidegger aborda como derivado da ontologia. Esse modelo passa a deixar de imperar pela gradual ineficiência na economia dos textos científicos e, na mesma medida, problematiza-se; contudo, Derrida afirma, "O fim da escritura linear é efetivamente o fim do livro" (Ibid., 108). A ressalva

\footnotetext{
42 "Portanto, não é necessário fazer uma escolha entre duas linhas de pensamento. Preferencialmente se deve meditar sobre a circularidade que as faz uma passar pela outra indefinidamente. Inclusive, rigorosamente repetindo esse círculo em sua própria possibilidade histórica, talvez para deixar algum deslocamento elíptico ser produzido na diferenciação da repetição, um deslocamento deficiente, sem dúvidas, mas deficiente de maneira que não é ainda — ou não mais - ausência, negatividade, não-Ser, falta, silêncio. Nem matéria, nem forma, nada que possa ser refeito por um filosofema, isto é, por alguma dialética, em qualquer que seja o sentido que determina a dialética. Uma elipse tanto de sentido quanto de forma: nem discurso completo, nem um círculo perfeito. Mais um menos, nem mais nem menos. Talvez uma questão inteiramente outra."
} 
vem do próprio filósofo quanto ao fato de que, nos nossos dias, ainda, novas escrituras são desdobradas nas fôrmas dos livros, literárias ou teóricas. A conclusão desses processos e desvios é absolutamente contundente: "Porque começamos a escrever, a escrever de outra maneira, devemos reler de outra maneira" (lbid.).

Essas dimensões de uma espécie de inadequação da escritura ao sistema linear e o lançar-se às dimensões temporais plurais e não lineares são fatos não concernentes aos problemas modernos, lembra Derrida, mas fazemse evidentes nos dias atuais. Teríamos de dizer, a partir disso, que Finnegans wake não é um livro, ou que o que faz dele um livro é o formato numerado e organizado para uma edição, que Ihe impõe linearidade específica. O que pensar dessa imposição de fôrma a um livro circular e efetivamente acessível de qualquer ponto - portanto avesso a qualquer ordenação, especialmente a uma numeração, que tanto especifica e prende? Talvez isso deva nos levar ao desprendimento dessa numeração, por mais útil que seja em termos de citação e compartilhamento. Ou, em vez de um desprendimento, uma atitude avessa a certa escravização que pode decorrer desse sistema que, em vez de pretensioso arranjo, traz desarranjo da estrutura circular que se deve perceber na obra.

Em seu Seminário de número 23 , denominado O sinthoma, ou Le sinthome - ou, ainda, "o santo homem" —, dedicado a James Joyce, Jacques Lacan parece atravessar, também, algo próximo à questão que aqui trazemos. Antes de citá-lo, talvez seja interessante remeter, ainda, especialmente no que diz respeito ao começo da citação do psicanalista, à célebre frase de Samuel Beckett a respeito do Finnegans wake, que é um livro não sobre alguma coisa, mas é a coisa em si. Lacan, em seu Seminário, diz:

Leiam as páginas de Finnegans wake sem procurar compreender. Isso se lê. (...) É uma sorte que haja uma única edição, o que permite designar, ao fazermos uma citação, a linha na página certa, isto é, na página que sempre terá o mesmo número. Se, como acontece com os outros livros, fosse preciso editar Finnegans wake com diversas paginações, como iríamos nos orientar? (LACAN, 2005, p. 161) 
Finnegans wake, então, só não é o fim do livro porque foi encaixado em uma estrutura linear, a despeito de sua natureza. Mas é o fim das barreiras linguísticas como estudadas historicamente $-\mathrm{e}$, novamente, a ponte supracitada com Derrida em "Gênese e escritura do Essai sur l'origine" se faz profícua, lembrando o que diz a partir de Jean-Jacques Rousseau: "Não haverá nem uma linha histórica nem um quadro imóvel das línguas. (...) As línguas são semeadas" (DERRIDA, 2011, p. 263). O dinamismo babélico que, como foi dito alguns capítulos atrás, transpassa para a tradução, afeta o leitor de maneiras distintas e desestabiliza a interação leitor-obra de uma maneira que tem certa medida de imprevisibilidade. O fim da barreira linguística se relaciona ao fim de uma barreira temporal.

Ainda sobre Rousseau, nesse mesmo texto, Derrida aponta a vontade do iluminista francês de esgotar todos os recursos da escritura, buscando univocidade, clareza e precisão, indicando a pontuação como "o melhor exemplo de uma marca não-fonética no interior da escritura” (Ibid., p. 277). Rousseau chega a dizer que seriam necessárias novas invenções em pontuação para que se extraísse o melhor da escritura, seu máximo, como pontos que indicassem, por exemplo, ironia e vocativo, este último com a intenção de diferenciar, na escrita, o homem que se proclama daquele homem que é convocado na linguagem. Podemos vislumbrar uma semelhança, curiosamente em sentido diametralmente oposto, entre Rousseau e o ímpeto joyciano: ao invés da busca por univocidade e precisão, Joyce parece buscar alcançar ou extrair, também, o máximo do trabalho que realiza no campo da palavra escrita, explorando, no entanto, o que se constrói em desbravamento de disseminação a partir do alcance do plural linguístico, isto é, daquilo que não proíbe ambiguidade, mas se farta dela.

Em muitos pontos do texto, o próprio Finnegans wake praticamente diz ao leitor, ou ao menos the indica formas de se debruçar sobre ele, dando pistas de suas premissas. $O$ excerto que mostraremos aqui traz a sugestão de que fatores como o tempo - plural - , a inflexão/pronúncia e as maneiras de se comunicar algo têm o poder de afetar diretamente no processo comunicativo que envolveria, idealmente, emissor, mensagem, código, receptor, como postulado pelo 
estruturalismo de Roman Jakobson. O próprio texto se anuncia em apelos a uma Babel, ou, mais especificamente, a um processo de babelização da(s) língua(s) e de deslocamento da emissão de mensagens em um suposto procedimento de comunicação:

\begin{abstract}
Because, Soferim Bebel, if it goes to that, (and dormerwindow gossip will cry it from the housetops no surelier than the writing on the wall will hue it to the mod of men that mote in the main street) every person, place and thing in the chaosmos of Alle anyway connected with the gobblydumped turkery was moving and changing every part of the time: the travelling inkhorn (possibly pot), the hare and turtle pen and paper, the continually more and less intermisunderstanding minds of the anticollaborators, the as time went on as it will variously inflected, differetly pronounced, otherwise spelled, changeably meaning vocable scriptsigns. (FW, 118.18-28) ${ }^{43}$
\end{abstract}

No próprio texto de Finnegans wake, portanto, admite-se ou até mesmo assevera-se que a linguagem, sob a dinâmica de um caráter mutável, não tem um destino certo, pontual no espaço e tampouco no tempo; seu remetimento pode lidar com o extravio, com a perda de seu destino. Em se tratando do texto literário, em que o destinatário não é unitário, essa possibilidade é ainda maior, especialmente em um texto como Finnegans wake, que remete à conexão entre todas as coisas no caosmos de tudo - algo que cria uma possibilidade de cadeia de remetimentos infinita.

Para Jean-Jacques Rousseau, o surgimento das línguas se dá na passagem do grito natural indomado pela racionalidade ao som articulado. Ao mesmo tempo, ele evoca o espectro de uma fala que se dá puramente em articulação, que seria uma língua morta, álgebra ou escritura, ou seja, resultaria na morte da fala. Para Jacques Derrida, "a morte, que não é nem um presente

43 Tradução de Donaldo Schüler: "Porque, Escritores de Babell, sofridores, se chega a isso, (e conversas de sótão o proclamarão do talhado com mais probabilidade, anoite-o, que a escrita no muro há de calorir a mente dos mentantes moventes na via mestra) cada persona, galgo ou algo no caosmo do Todo de alocuma forma conectado com o pingalim em piruetas do pingo moviase e mundava em cada parte do tempo: o estojo movente (possivelmente o tonteiro) o papel a tinta no pipel das fibulosas lebre e tortuga, os constantes mal-entendidos dos descolaboradores mais ou menos entrementados, enquanto o fluir do tempo será variabilmente infletido, diferentemente pronunciado, riversamente ortografado, grafissignos de vocábulos de sentido cambiante." 
por vir nem um presente passado, trabalha o dentro da fala como o seu rastro, sua reserva, sua diferência interior e exterior: seu suplemento" (DERRIDA, 2011, p. 385).

Levando isso em consideração, e também o sonho de Rousseau pela língua que, por fim, seria inarticulada, Jacques Derrida questiona, quase concluindo a sua Gramatologia: "E se a cena do sonho for sempre uma cena de escritura?" (Ibid., 386). Sigmund Freud apontava ser pertencente à escritura, talvez, o mundo dos sonhos. Finnegans wake, sendo o próprio livro da noite e do sonho, é, então, escritura na mais bem sucedida fuga da linearidade. 
Capítulo iv:

FLUIR E RETORNO 
O problema estrutural em Finnegans wake é, segundo afirmamos, um problema intrinsecamente constituído na questão da dimensão temporal da existência, a começar por abranger o tempo da leitura da ficção - até alcançar as explicações do tempo do sonho e outras analogias. Para além do tempo do sonho, podemos pensar, contrariamente a certa concepção temporal aristotélica de momento fugidio, de linearidade e homogeneidade, a concepção temporal da tradição semita, que trata de simultaneidade, assim como uma concepção vinda de Bergson ou de Heidegger. Nessa tradição hebraica, ao invés da mensurabilidade que secciona a vivência, há a concepção cairológica, se podemos assim colocar, relacionando-a ao tempo do kaıpós (em vez da cronológica, isto é, o tempo na lógica de kpóvoৎ). 
Para considerar essa visão procedente, no entanto, dificilmente seria profícuo simplesmente apontar momentos específicos do livro em que isso aconteça, sem considerar também o todo, em recortes que ilustrem afirmações. O entendimento de aspectos estruturais do Wake relacionados a concepções de temporalidade é bastante visível, considerando os paradigmas viquianos de que Joyce partiu ou simplesmente observando o início do livro conter uma frase cortada, indicando uma estrutura in media res especialmente explícita, mais do que se especula em Ulysses, por exemplo. Os caminhos que o texto segue, porém, em termos de tempo, ultrapassam os aspectos mais pulsantes e chegam a ser tortuosos, uma vez que mudam a todo tempo, desde o tratamento dado a personagens até a ambientação, passando pelo vocabulário sempre mutante que remete também linguisticamente a outros tempos, com usos anacrônicos ou deslocados na diacronia dos idiomas entremeados, ao contrário do que uma pretensão naturalista teria, de reproduzir um tempo e espaço pontuais da realidade - e, claro, pela narrativa desmantelada. Assim, ainda que seja difícil ilustrar certas afirmações sobre Finnegans wake pontualmente, podemos rememorar passagens e buscar e alguns destaques possíveis.

No quinto capítulo do livro I, que se inicia com um parágrafo surpreendentemente curto - após uma série de parágrafos longos, desde as primeiras páginas da obra - temos uma espécie de apresentação mais formal e direta de uma das personagens principais da obra, Anna Livia Plurabelle, a mulherrio. O documento envolve diferentes personagens, no entanto, no que diz respeito tanto à sua redação, quanto ao seu envio. Diz o trecho:

In the name of Annah the Allmaziful, the Everliving, the Bringer of Plurabilities, haloed be her eve, her singtime sung, her rill be run, unhemmed as it is uneven! (FW, 104.1-3)

\footnotetext{
${ }^{44} \mathrm{Na}$ tradução de Donaldo Schüler, em que o tradutor evoca a religiosidade da fala de oração: "Em nome de Annah, a Allmissassombrosa, a Sempreviva, a Portadora de Plurabilidades, santificada seja sua evigília, venha o reino de seu canto, ritmem suas rumas sem peias assim na terra como no céu!".
} 
O que esse parágrafo apresenta, em verdade, é a vinda de sua voz, sua chegada ao leitor por meio de uma carta-manifesto ("mamafesta") sem título que será mostrada em seguida aos leitores, nesse mesmo capítulo. Desenha seu lugar de inscrição, aquele onde poderá se despir em translúcida sinceridade e apelo. No entanto, ainda que seja introduzida sua carta e, portanto, sua voz e sua presença, o parágrafo se inicia com "in the name of...", isto é, "em nome de...". A expressão não serve aí para transferir a fala a alguém que a represente, como se houvesse um outro personagem que falasse em seu nome, em seu lugar, forjando sua assinatura; serve para sobrepor outras vozes à sua, na medida em que Anna Livia não se ausenta para que falem por ela, mas há uma comunhão de outras vozes que tomam o lugar da fala concomitantemente. Não há uma passagem da voz de uma pessoa para outra, mas uma assinalação de polifonia, isto é, de multiplicidade em simultaneidade.

Primordialmente, diversos indícios nos levam à leitura de Anna Livia como uma divindade aí evocada. As referências nesse trecho são basicamente islâmicas. Essa evocação não deixa de lembrar, em referência paralela à antiguidade ocidental, a forma como todo poema épico deve se abrir, evocando e pedindo auxílio às musas para fazer o texto acontecer, surgir, fluir; mas podemos vislumbrar aquela religião abraâmica já ao vermos o nome de Anna Livia ao lado de um epíteto de tamanha imponência, "the Allmaziful", que remete a "all-merciful" e, por conseguinte, também à maneira consagrada de se referir a Alá, "Allah, the All-merciful".

A abertura desse parágrafo ecoa, ainda, tanto em similaridade fonética quanto nas relações intertextuais que permite, o termo "Bismillah", que reaparece a cada sura (cada capítulo do Corão), geralmente nessa mesma posição, dando início ao texto ali contido. O eco, aqui, é efetivamente de repetição, uma vez que "Bismillah" significa exatamente "In the name of Allah, the All-merciful'. Por maior que possa ser a importância das repetições de termos, temas e referências no Wake, devemos ter o cuidado de não acreditar que elas só existem se perceptíveis, digamos, a olho nu, mesmo que sob a óptica meticulosa de quem procura as reproduções explicitamente visíveis. 
Jacques Derrida, a respeito de estrutura textual, diz na seção intitulada "A fita de máquina de escrever", integrante da coletânea Papel-máquina, que "a lógica do acontecimento textual como inscrição material" impede uma regulação com progressão e regressão, isto é, com "o processo temporal como habitualmente se pensa", mas sim regulado pelo próprio acontecimento ou ocorrência do texto, "portanto pela singularidade de uma única vez" (DERRIDA, 2009, p. 86). É caracterizada, portanto, uma forma própria de experiência, de maneira que somente uma visão fenomenológica respeitaria tamanha especificidade.

No esteio desse raciocínio, faz-se necessário reafirmarmos que tal tempo, relacionado ao escritural, bem como às ações propriamente de escrita e de leitura, tem peculiaridades próprias e, por isso, uma dinâmica de consequências tanto variáveis quanto incontroláveis. A escrita prevê o que será do que jorrou dela, e também como chegará ao leitor, mas sabendo que deve falhar nessa previsão. O tempo da leitura é um presente inescapável que tem de lidar com o passado irrecuperável da leitura da linha anterior: ainda que se volte e leia novamente o que já se leu, a experiência é outra. $O$ deparar-se com o texto, matriz de estranhamento frente à língua, ocorre sempre na singularidade.

Derrida traz ainda afirmações a respeito do acontecimento na literatura, remetendo a certa categoria de materialidade do texto - materialidade de um âmbito metafísico, enquanto conceito filosófico; diferente, portanto, de matéria - que determina o conceito de acontecimento (ou a acontecimentalidade) textual, associado à desconstrução. Essa conjectura é pertinente na medida em que essa operação desconstrutiva, para Derrida, tem sempre como alvo ou "implica sempre um processo de desmetaforização" (Ibid., 131), em que se revela a existência de articulações ocultas em totalidades antes aparentemente monádicas. Assim, o que repousa sob o texto, quase silenciosamente, mas é visível em sua superfície - em sua sintaxe, em sua estrutura narrativa, em seus processos metonímicos mais evidentes - é o que uma leitura desse formato alcança, e é a abordagem que se propõe aqui na leitura de Finnegans wake, considerando as disseminações de sentido pelo texto. 
Retornando ao Wake: uma série de epítetos se segue, todos com inicial maiúscula, indicando que o parágrafo se refere a uma autoridade, amarrando os adjetivos ao nome próprio, como corolários de um pronome de tratamento especial: "the Everliving, the Bringer of Plurabilities". O restante do capítulo não contém mais referências islâmicas. $O$ que apareceu no primeiro parágrafo não foi uma chave para a leitura do que viria depois, mas referencias que se entrecruzaram dentro do mesmo parágrafo e depois, aparentemente, não nos servem para nada, podendo imaginar que um leitor não as perceba e/ou as ignore e continue sua leitura sem prejuízo. Anna Livia não é Allah, nem Ihe é equivalente ou consiste em uma paródia dele, mas a figura de Allah surge por detrás da mulher-Liffey.

A expressão "in the name of...", além de engendrar a referência à fala islâmica (e à fala católica com o "em nome do Pai, do Filho e do Espírito Santo..."), aponta fatos narrativos. É notável, no parágrafo, que essa expressão não consiste em uma transmissão, naquele momento, do poder de enunciação da própria Plurabelle a outrem a partir desse ponto. Lembra, de maneira bem humorada, no entanto, um anúncio real ou oficial sobre alguma questão decidida pela instância maior de uma hierarquia. Nesse sentido, há uma intermediação nesse anúncio. Há, ainda, uma interposição de duas outras personagens da obra quando a carta-mamafesta nos aparece: a de seus filhos Shem e Shaun. Shem, the penman, escreve a carta cujo conteúdo Ihe é transmitido por Anna Livia, e Shaun, the postman, encarrega-se de entregá-la, funcionando como mensageiro.

Com o personagem de Shaun, e especialmente quando the é atribuída essa tarefa, é inevitável lembrarmo-nos da relação entre mensageiro e hermenêutica, vislumbrada etimologicamente. Tomamos a explicação de Heidegger a respeito do termo, neste caso didática e objetiva. Do diálogo com professor Tezuka, da Universidade Real de Tóquio, nasce o texto "De uma conversa sobre a linguagem entre um japonês e um pensador", de 1953/1954, publicado em A caminho da linguagem. Questionado por Tezuka a respeito do uso dos termos "hermenêutica" e "fenomenologia" em Sein und Zeit, ambos 
posteriormente abandonados por Heidegger, o filósofo alemão responde a seu interlocutor:

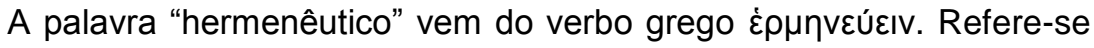
ao substantivo que se pode articular com o nome do deus Hermes, 'Epuńs, num jogo de pensamento mais rigoroso do que a exatidão filológica. Hermes é o mensageiro dos deuses. Traz a mensagem do

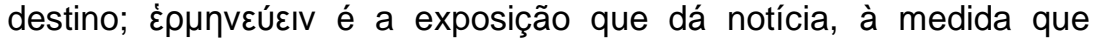
consegue escutar uma mensagem. Esta proposição se transforma em interpretação da mensagem dos poetas que, nas palavras de Sócrates,

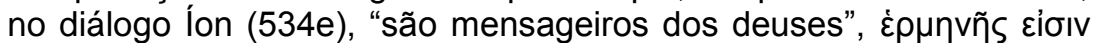
Tũv $\theta \varepsilon \tilde{\omega} v$. (...) Assim, hermenêutico não diz interpretar, mas trazer mensagem e dar notícia. (HEIDEGGER, 2011, pp.96-97)
\end{abstract}

Shem, the penman, cujo epíteto prova o quanto assumidamente é a encarnação do poeta, tem em Shaun, assim, seu correspondente mensageiro, e essa esquemática fica ainda mais clara na dinâmica da carta da mãe, Anna Livia, espécie de musa inspiradora evocada para a realização da escrita. O "in the name of..." opera na marcação dessa impureza de voz da personagem mãe, deixando explícito para o leitor que o conteúdo expresso ali percorre um caminho indireto. Faz-se necessário duvidar do acesso que podemos ter à voz que nos remete o conteúdo do que lemos, até a chegada de seu monólogo fluvialmente verborrágico. Poder-se-ia afirmar que a voz de Anna Livia só realmente toma seu lugar e domina o texto, tomando suas rédeas, ao fim do livro IV, sem mensageiros tramitando mensagens em seu lugar, ainda que aparentes intromissões eventuais sempre aconteçam. Certamente, porém, a dúvida que Finnegans wake impõe, segundo traçamos, a respeito de voz discursiva possibilita uma teorização a respeito da impossibilidade de se destilar a sincronia de uma voz, uma fala, uma entidade ou personagem. A improbabilidade desse isolamento ou dessa purificação de categorias e instâncias narrativas nos lança em aporias textuais diversas, confirmando a compreensão de que a leitura dos capítulos não cumpra expectativas de clareza e de unidade, mas que sejamos sempre obrigados a questionar o que mudou e que nova polifonia em aparente caotização está sendo desenvolvida. 
Outros exemplos dessas simultaneidades diversas estão no capítulo 11, em que vimos a mesma indefinição entre falas, tempos e espaços, unindo a fala embolada coletiva das pessoas ocupando o pub à do rádio e à de uma narração de história aparentemente nem do pub, nem do rádio; entre as elucubrações das lavadeiras, no capítulo de ALP, com a sonoridade dos ecos e a presentificação de uma série de falas que ouviram e reproduzem de diversas maneiras; as sessões de julgamento de HCE, permeadas por intromissões; os diversos devaneios oníricos que colocam HCE em situações insólitas, espalhados por muitos capítulos e passando pelas metamorfoses das personagens em outras pessoas e elementos da natureza; as margens, no capítulo 10, que colocam no mesmo espaço de página vozes completamente distintas em origem, conteúdo e forma, em que cada espaço das margens se destina a um dos irmãos: Isolda ocupa as notas de rodapé e, circundando todo o texto, Shem e Shaun. Mesmo nessa divisão de espaço, as vozes não estão isoladas: as margens laterais eventualmente se trocam e, comentando-se intercaladamente, misturam assuntos e referências, desestabilizando a verdade ou a unidade do que seria, tradicionalmente, a voz narrativa central.

A dita correspondência dicotômica entre Shem e Shaun se explicita ainda na relação de Shaun, como o mensageiro, com o deus Hermes. Como é dito na citação de Heidegger, o mítico Hermes tem uma relação com a origem da hermenêutica, ainda que por vias etimológicas indiretas (passando pelo verbo $\dot{\varepsilon} \rho \mu \eta v \varepsilon u ́ \varepsilon I v)$. Por outro lado, Shem, o poeta, se opõe a Shaun ainda nesse quesito: um irmão está aberto ao ambíguo, enquanto outro se concentra na interpretação una. Sendo um mensageiro, assim como Hermes era mensageiro dos deuses, Shaun se preocupa com a emissão da mensagem, com fazê-la alcançar o destinatário exatamente como deve chegar, sem extravio ou desvio. Shaun busca verdades, ironizando a existência do próprio Wake, enquanto Shem se instala no terreno das possibilidades, inclusive da possibilidade de que o próprio livro se faça. No livro II, capítulo 9 - capítulo 1 na divisão de Campbell e Robinson (2013), "A hora das crianças" —, os irmãos se separam entre as luzes (Shaun) e as trevas (Shem), caos/o caminho confuso do perder-se (Shem) e a redenção e autocontemplação (Shaun); isso é assinalado como uma 
separação quase chocante, como de Dom Quixote e Sancho Pança, de possibilidade remota.

A dicotomia entre os irmãos, no entanto, é transgredida na medida em que se completam na divisão de tarefas materializada pela carta de Anna Livia Plurabelle. O que se daria como uma pura oposição se dissolve em uma espécie de paralelismo: cada um dos irmãos tem seus preceitos, seus caminhos que não se tocam; mas seguem lado a lado e, ainda que tenham nuances próprias, são dotados de características que operam por contraste. O que os separa e diferencia é mútuo em suas respectivas caracterizações, havendo uma união maior que a meramente consanguínea, ainda que definitivamente não sejam personagens intercambiáveis. Operam, na verdade, como as relações entre todos os familiares do núcleo de Finnegans wake: por similaridade e diferenciação, com a caracterização de cada um deles sempre interligada e passando pelas relações de parentesco - seja no incesto, seja na continuidade geracional que gera espelhamento e desdobramento, seja nos pares complementares e assim por diante. O tempo do parentesco, assim, pode caotizar uma linearidade cronológica; é um anacronismo de cruzamentos diversos mais do que uma união ou intersecção de sincronias unitárias - de tempos individuais -, nem a diacronia familiar, como seria se interpretássemos o coletivo como história e memória.

A carta-mamafesta de Anna Livia, portanto, tem o seu caminho anticircularizado, tornado elíptico, com um "retorno deslocado" da compreensão de Jacques Derrida, e isso ocorre mesmo antes da chegada da mensagem, já havendo a problematização de seu remetente: através de Anna Livia, a mensagem desloca-se por seus filhos em desvios não rastreáveis. É desintegrada a noção de unidade nesse percurso, bem como a possível centralidade do emissor. Estando a noção de presença e a noção de centro intimamente ligadas, ambas se esfarelam simultaneamente. Os espaços de voz em que os remetimentos se interseccionam seriam, no Wake, repensados. Finnegans wake, então, sendo o próprio livro da noite e do sonho, é escritura em fuga do linear que não só desvia como se estranha e se exila do terreno comum 
da centralidade e dos eixos estáveis, das repetições criadoras de identidade, da mensagem enviada em linha reta — em uma potente polifonia.

A distância entre diferentes vozes implica que existam diferentes temporalidades. O filósofo franco-lituano Emmanuel Levinas discorre sobre o tempo partindo de sua investigação central: a dicotomia do mesmo e do Outro (que, em verdade, se estabelecem em relações éticas complexas, superando um caráter meramente dicotômico). Em Autrement qu'être ou au-delà de l'essence (1974), diferencia três possibilidades de leitura temporal, sendo a primeira delas o tempo do mesmo, a pura sincronia de um eu que vive seu tempo de um ponto de vista determinado, até o ponto em que não afetado por alteridades paralelas. O estabelecimento de uma diacronia só se dá com a intromissão desse outro, intromissão em geral inevitável, de maneira que não há mais um só passado, nem uma perspectiva unificada do tempo presente. A última instância seria 0 ponto do anacronismo, em que a dualidade eu-outro, como duas entidades paralelas ou entrecruzadas, se multiplica em uma diversidade de passados, futuros e uma impossibilidade de presente único e de uma perspectiva solitária intocada.

Uma obra literária apresenta, em princípio, uma sincronia: há o texto, uma porção de enunciados congelados, prontos a serem evocados num presente qualquer de um leitor que com ele se depare. Só pode ser lido em um presente, um instante, na linearidade de cada letra que sucede outra, cada palavra e linha em ordem inertes. Nessa interação há o cruzamento de outro tempo apenas a partir da abordagem leitor, um mesmo, um eu que vai com sua sincronia própria, seu tempo presente, à abordagem do texto. No entanto, a sincronia que se apresenta não é ativada senão no contato com ele, na leitura por alguém. Ao invés de um cruzamento, então, poder-se-ia pensar na retirada do texto de uma suspensão temporal. A obra ocupa um lugar de nenhum tempo, até que é chamada a ocupar um presente de alguém cuja temporalidade the é imposta e domina a interação leitor-texto. Se pensarmos tempo de maneira contígua a espaço, a obra ocuparia, assim, um não-lugar. A sincronia do texto acompanha a linha do tempo de quem quer que seja o centro dessa condução: seja um 
narrador personagem, seja um narrador onisciente que nos guia pelo trilho dos fatos, seja fluxo de consciência e o tempo do monólogo interior.

Isso nos impõe o problema: que sincronia é inerente ao Wake? Há uma incompatibilidade ainda entre o tempo presente do leitor e a não-sincronia do texto com que se depara. Havendo uma sincronia na obra, o leitor e seu tempo se relacionam de um para um com o tempo do outro; no entanto, não se pode definir com precisão (ou mesmo sem!) a linearidade do Wake, menos ainda definir um personagem que detenha essa perspectiva, de quem parte a temporalidade. No monólogo, poderíamos afirmar que haveria a sincronia de Anna Livia; no entanto, as intromissões são tantas que vemos claramente um cruzamento de temporalidades diversas. Isso é favorecido pela forma do monólogo, por seu próprio modo, assim como seria em qualquer tentativa de se trabalhar a partir de um fluxo de consciência e transformá-lo em técnica; não é, porém, justificado por ele, uma vez que há a possibilidade de que um monólogo interior narrado tenha uma temporalidade sincrônica absolutamente palpável. 0 final (se podemos assim dizer) de Finnegans wake, no entanto, sugere um continuum que aponta a um futuro, à substituição da geração anterior pela que a sucede. O capítulo se inicia com "Sandhyas!", que lembra tanto Sunday (o Sol que está nascendo na manhã indica o novo dia, já que o sonho de Earwicker pode ter se passado em uma noite de sábado), quanto um saṃdhí (संधि), termo sânscrito que significa "junção" ou "articulação" e remete à cosmologia do Bramanismo, em que se denominam os intervalos entre as yugas (as quatro idades: satya, treta, dwapar e kali yuga) de sandhyā e sandhyānsa. Assim, o encaminhamento para o final — do sonho, do livro, de uma idade/fase — se dá de maneira prismática, sem encaminhar pontualmente um fechamento temporal específico, pois não se limita à cronologia hindu, nem à da narrativa. Os tempos verbais são claramente confusos; dizem-se anulando-se: "The child, a natural child, thenown by the mnames of, (aya! aya!), wouldbewas kidnapped at na age of recent probably, possibly remoter" (FW, 595.34-36) ${ }^{45}$. A incerteza se explicita:

45 Tradução de Donaldo Schüler: "Um menino, filho natural, então conhecido pelos mnomes de, (aya! aya!), podequefoi raptado em data recente provavelmente, também pode que mais remota". 
"would be" e "was" se unem no que é passado e, ao mesmo tempo, possibilidade; a hesitação confirma: um "provavelmente" recente, mas também possivelmente "remoto". Não há apenas dúvida entre um ou outro tempo: como garantir que o passado de fato passou?

Se concebermos o Wake todo como um livro de sonho, seja do Humphrey, seja de Anna Livia, talvez a consciência de quem sonha seja essa figura centralizadora. A temporalidade do sonho, porém, se instalaria como outro óbice a essa definição, já que não possui um tempo cronometrável e, portanto, sua calculabilidade se dissipa de qualquer maneira. Sem evocá-las conscientemente, memórias compõem qualquer sonho; mas podem ser distorcidas, constituindo devaneios que são, na verdade, nada além de conjecturas ficcionais. Imiscuem-se desejos que vislumbram um certo futuro do âmbito do previsível e, ainda, o presente do sonhador, que dorme, em sono leve ou pesado, em algum lugar, calmo ou barulhento, confortável ou não, após ter tido um dia bom ou ruim, agitado ou tedioso. Se pensássemos no sonho fora da ficção, portanto, muito haveria de ser considerado; na ficção, se é concebido um personagem que sonha a narrativa, ou que sonha uma escritura — para falarmos junto com Freud -, certamente não se partiria do princípio de que há uma sincronia, pois o tempo dessa produção onírica não será uno, mas antes de aspecto múltiplo.

Citamos sincronia, anacronismo, termos previsíveis em uma abordagem sobre o tempo. Podemos, no entanto, empregá-los de uma maneira mais específica a partir de alguns apontamentos levinasianos que perpassam a questão da temporalidade pela via ética e ontológica. A ética metafísica de Emmanuel Levinas é pautada em investigações fenomenológicas cuidadosas e no olhar sobre as exigências morais, a alteridade e a justiça - que constituem o ser humano desde o face a face um-Outro até o todo da vida em sociedade. Um desdobramento do título de uma de suas obras, Autrement qu'être ou audelà de l'essence, isto é, além do ser, outramente que ser, outro que (no sentido negativo) ser, indica a intenção de ultrapassar o ser como concebido até então nas discussões da ontologia, remetendo indubitavelmente ao legado daquele que resgatou a questão-do-ser (Seinsfrage), até então esquecida: Martin 
Heidegger. Em Sein und Zeit (1927; 2012), Ser e tempo, o filósofo de Meßkirch retoma o ser das trevas em que este estava envolto, apontando resumidamente três preconceitos que imperavam como entraves de sua investigação, a saber: sua suposta inerente universalidade; o atravanco inevitável em qualquer tentativa de definição e, por fim, sua totalidade em si, autossuficiência.

\begin{abstract}
Aquilo que de modo fragmentário e numa primeira investida foi um dia arrancado dos fenômenos pelo supremo esforço do pensamento de há muito se trivializou. (...) Sobre a base dos pontos-de-partida gregos da interpretação do ser construiu-se um dogma que não só declara supérflua a pergunta pelo sentido de ser, mas além disso sanciona sua omissão. Diz-se: "ser" é o conceito mais universal e o mais vazio e, como tal, resiste a toda tentativa de definição. (HEIDEGGER, 2012, p. 33)
\end{abstract}

Estabelece já na introdução de seu tratado que o objetivo é "a elaboração concreta da pergunta pelo sentido de 'ser'" e que o tempo, assim como aparece em segundo lugar no título, constitui no conteúdo de toda a obra apenas uma "meta provisória" no que for pertinente para direcionar "o horizonte possível de todo entendimento-do-ser em geral" (Ibid., p. 31). O tempo é um caminho interpretativo para o ser, este sim o centro da investigação de Heidegger. Assim, partindo da revisitação do que a ontologia relegou como terras inférteis, desenvolveu seu Dasein, matriz do entendimento-do-ser, o ente cuja maior possibilidade-de-ser é a de perguntar (Frager, perguntante). Esse retorno à ontologia, à máxima pergunta ontológica, primordial, é acompanhado então pela temporalidade, sentido do ser do Dasein, na medida em que se constitui como aquilo a partir de que ele é capaz de entender e processar um algo.

Assim como a Seinsfrage permaneceu intocada, Heidegger destaca que o conceito de tempo se manteve praticamente inalterado desde Aristóteles, mesmo passando por Henri Bergson (dizendo que o filósofo francês é mais aristotélico do que pensa), e reteve também o preconceito de um entendimento vulgar da função ontológica autossustentável. Não se pode, porém, escapar desse outro resgate. Direciona-se assim à "destruição do conteúdo transmitido pela ontologia antiga, tarefa a ser levada a cabo pelo fio-condutor da questãodo-ser" (Ibid., p. 87), mas uma destruição (Destruktion) que "não quer sepultar o 
passado no nada", pois "ela tem um propósito positivo e sua função negativa permanece inexpressa e indireta" (Ibid., p. 89). Toda essa necessidade é justificada:

Porque o ser só pode ser apreendido cada vez na perspectiva do tempo, a resposta à questão-do-ser não pode residir numa proposição isolada e cega. A resposta não é entendida na mera reiteração do que é enunciado em proposição, sobretudo se é posta em circulação como resultado flutuando no ar para mero registro de uma informação sobre um "ponto-de-vista" que talvez se afaste do modo de tratamento até agora usual. (Ibid., p. 79)

O tempo como horizonte interpretativo do ser não é uma escolha heideggeriana, por assim dizer, em termos fundantes. A ontologia antiga, interpretando o ser a partir e através do mundo, isto é, da natureza, acaba por

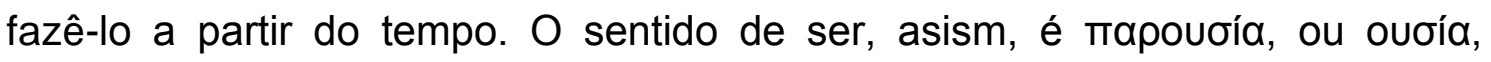
presença. Heidegger cita brevemente que a tese ontológica de Parmênides de Eleia influenciou diretamente Tomás de Aquino, que a absorveu, no que diz respeito à alma do ser humano e do vocĩv, o perceber, que guiam a questão-doser e colaboram para caracterizar o Dasein em sua precedência ônticoontológica. No poema fragmentado "Sobre a natureza", ou "Da natureza", de Parmênides, única obra considerada sobrevivente do filósofo pré-socrático, encontra-se um eixo que se disseminou por toda a prática filosófica do ocidente:

... pois o mesmo é pensar e ser.

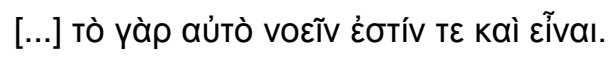

(Frag. III)

Para Parmênides, o ser está no que aparece e é inútil tentar conceber o não-ser, de maneira que se faz necessário, para a definição do ser, pensando nos termos do que se dá à aparição e, portanto, no tempo presente. Os dois

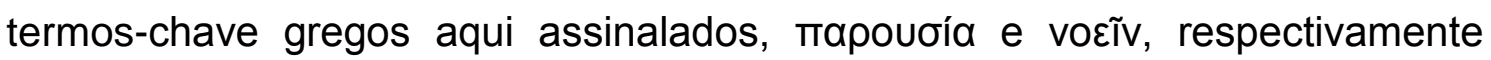
presença e perceber, levam a um outro, intimamente ligado ao modo da 
discussão de Heidegger, bem como a Levinas e outros filósofos preocupados

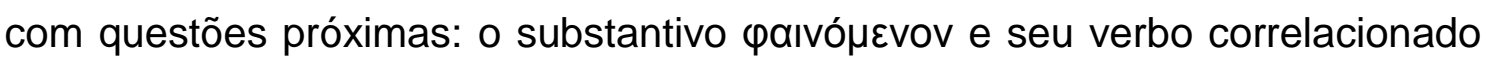

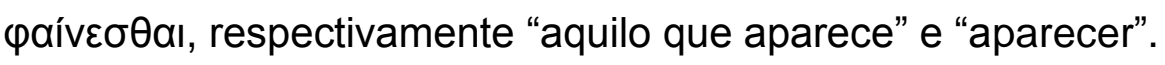

O trecho da obra remanescente de Parmênides explica poeticamente a sua ontologia calcada nas relações que apontamos como envolvidas nessa teia vocabular:

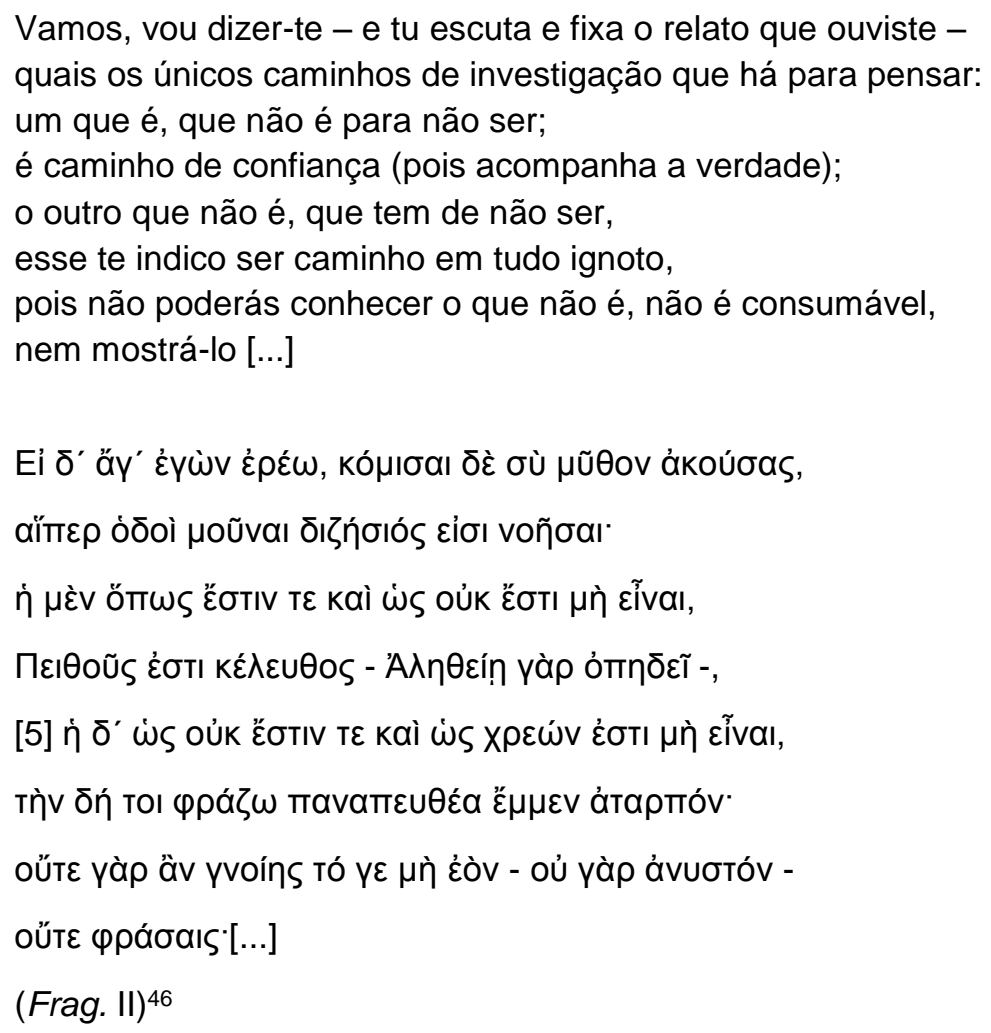

O brilho da aparência não significa aí apenas um clarificar das coisas no momento do mostrar, pois, de alguma maneira, acaba por esconder o ser; ainda assim, somente a presença pode definir sua existência. Como dissemos, essa necessidade funda uma relação forçosa com o tempo presente, que se estabelece como referência para qualquer ente. Justifica-se aí que Heidegger

46 A tradução de José Gabriel Trindade Santos, de 2002, é pautada no texto original (como também citamos aqui) estabelecido pelo filólogo clássico escocês John Burnet, na ocasião de sua tradução para o inglês, feita em 1892. Todas as citações de Parmênides, inclusive a da página anterior, pertencem a essa mesma tradução. 
tenha se dedicado também ao tema do tempo: era necessário discorrer sobre ele para falar do ser, especialmente tendo a intenção de desmontar essa ontologia clássica, por "ser" e "tempo" serem, de fato, inseparáveis nessa definição ontológica tradicional.

Tamanho paradigma resulta em um dito "privilégio do presente" nas investigações filosóficas a esse respeito, sobre o qual discorre Jacques Derrida em Marges de la philosophie (1972; 1991).

O privilégio do presente (Gegenwart) teria já marcado o Poema de Parmênides. O legein e o noein deviam apreender um presente sob a espécie daquilo que permanece e persiste, próximo e disponível, exposto diante do olhar ou ao alcance da mão, um presente na forma da Vorhandenheit. Essa presença apresenta-se, é apreendida no legein ou no noein segundo um processo "estrutura temporal" é de "pura apresentação, de pura permanência (reinen "Gegenwirtigens"). (DERRIDA, 1991, p. 66)

Derrida não aponta e até reitera um certo reducionismo linguístico que Heidegger comete ao considerar oủoía exatamente o mesmo que presença, que seria a парouбía, repetindo essa mesma relação. Heidegger afirma diversas vezes: "a determinação do sentido do ser como mapouoía ou como oủoía, o que ontológico-temporalmente significa 'presença"” (HEIDEGGER, 2012, p. 95); "O ente que nele [no ser] e para ele se mostra e é entendido como o propriamente ente recebe portanto sua interpretação em referência ao pre-sente (Gegen-wart),

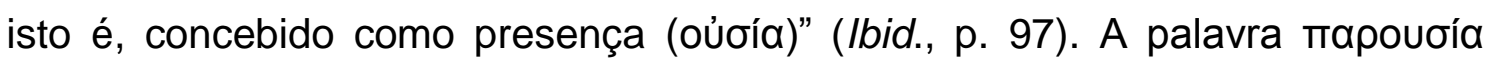
significa, de fato, presença, tanto temporal quanto espacial, não sendo mero sinônimo de seu termo formante oủoía, particípio presente do verbo "ser", na forma feminina (o que o aproxima da tradução consagrada para "substância", que Heidegger critica, ou algo que se aproxime de aquilo que vem sendo) que forma também ámoưía, aquilo que não é, que não vem sendo (por analogia, ausência).

A rigor, esse termo em grego é composto por uma dupla maneira de dizer o ser: a essência diz o ser no sentido "do que é a coisa", e a existência no sentido "de que a coisa é". (...) Mesmo levando em conta 
que é esse segundo sentido [o que excede a referência existencial] que prevalece, ele não é o único, motivo pelo qual Heidegger traduz ousía por Seiendheit, em um claro esforço para imprimir uma adaptação literal dessa ambiguidade do termo em grego. (...) Ousía fazia parte do vocabulário corrente entre os gregos e indicava e caracterizava bens imobiliários, propriedades e riquezas. (...) Nesse sentido, o ser equivale a um bem que deve sempre ser presente e constante, ousía é em primeiro lugar o que permance (para), é parousía, uma presença constante. (BOUTOT apud NASSER, 2006, pp. 117-118)

Essa polissemia, então, não pode ser reduzida a uma equivalência pura

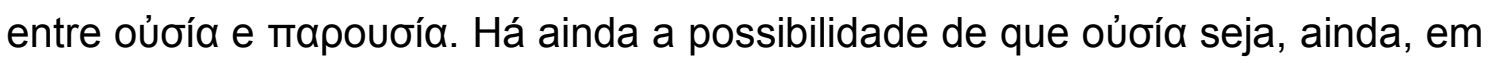
certos contextos filosóficos, essência. A relação do tempo com a ontologia tanto de Platão quanto no que diz Parmênides em seu poema fragmentado é inegável e permanece intacta, de maneira que o ser seja um permanecer no presente, permanecer na presença, estar no presente.

Jacques Derrida traz a aporia de Aristóteles na Física IV, mostrando que o paradigma trazido - o dito privilégio do presente - já era conhecido não só por Heidegger, mas em toda a história das investigações ontológicas desde a Antiguidade. O presente como tempo padrão caracteriza o tempo na metafísica. Todo outro tempo, passado ou futuro, é tomado a partir desse conceito central. No entanto, "o tempo é o nome da impossível possibilidade", de maneira que um agora é o mesmo e outro/novo ao mesmo tempo:

O sentido do tempo é pensado a partir do presente, como não-tempo. E não pode sê-lo de outro modo; nenhum sentido (qualquer que seja o sentido em que o entendamos, como essência, como significação do discurso, como orientação do movimento entre uma arquia e um telos) pôde jamais ser pensado na história da metafísica de outro modo senão a partir da presença e como presença. (Ibid., p. 87)

No monólogo de Anna Livia, vê-se, talvez, pela única vez em todo o livro, uma supremacia do tempo presente se instaurando com o despertar - ainda que o sonho precise de uma pessoa dormindo em um dado tempo "presente", o sonhador se ausenta desse tempo em direção ao tempo do sonho, que se caotiza. Com o anúncio do fim da noite, no entanto, vemos uma recuperação 
gradual de um tempo, como o trecho a seguir, em que uma contagem intercalada entre as frases faz espécie de escansão:

\footnotetext{
Passing. One. We are passing. Two. From sleep we are passing. Three. Into the wikewades warld from sleep we are passing. Four. Come, hours, be ours!

But still. Ah diar, ah diar! And stay. (FW, 608.33-36) ${ }^{47}$
}

Como os passos de um balé ou de uma dança que indica o tempo da coreografia e finalmente o fim dos movimentos (com "stay") e em meio a suspiros de Anna Livia (ah, dear), encaminhamo-nos para longe do breu, das sombras que não progridem no tempo, mas pairam entre fases fluidas. Anna Livia não instaura, no entanto, com a chegada do dia, sincronia ou diacronia puras: "Yet no body is presente here which was not there before. Only is order othered. Nought is nulled. Fuitfiat! (FW, 613.13-14) ${ }^{48}$. Apesar de estar sendo instaurada uma espécie de nova etapa externa ao onírico, Anna Livia nos afirma que só o que muda é a ordem, mas nada está sendo efetivamente deixado para trás, relegado ao ostracismo de um tempo passado: nada é nulo. "Fuitfiat!" tem o fuit que lembra "fugir", do francês, e fiat o latim de fez-se, feito, está feito; indica que algo foge, mas algo também se faz, aparece (fiat lux).

Há passagem, sim, como ela anuncia reiteradas vezes, do sonho para o despertar, da noite para o dia, para a claridade; no entanto, o passado não se cristaliza como antecedente que nada mais tem de relação com o que vem, uma vez que as reminiscências não se afastam. O que é cíclico pode instaurar uma espécie de privilégio do presente na medida em que, com o estatuto do ricorso, tudo retornar significa se fazer presente novamente. Não há rememoração de algo que ficou no passado e cuja presença foi substituída por plena ausência. Ao contrário: o que há é uma eterna (re)presentificação do que se passou, seja

\footnotetext{
47 "Passagem. Um. Passamos. Dois. Do sono estamos passando. Três. Ao vasto visto mundo do sono passamos. Quatro. Venham eras, a nossas horas!

Silente. Ah, dea, ah, dia! E stá."

48 "Porém aqui não tem ninguém que já cá não esteve antes. Só que a ordem foi outrada. Nada se anulou. Fuitfiat!"
} 
com o caráter espectral do que sempre ronda, do que resta em caráter fantasmático e fantasmagórico, seja do efeitvo retorno de acontecimentos reiterados. $O$ tempo se reinventa de maneira que o conceito de lembrança e ideia de memória se redefinam diante do fim que se aproxima ao mesmo tempo em que anuncia uma revinda:

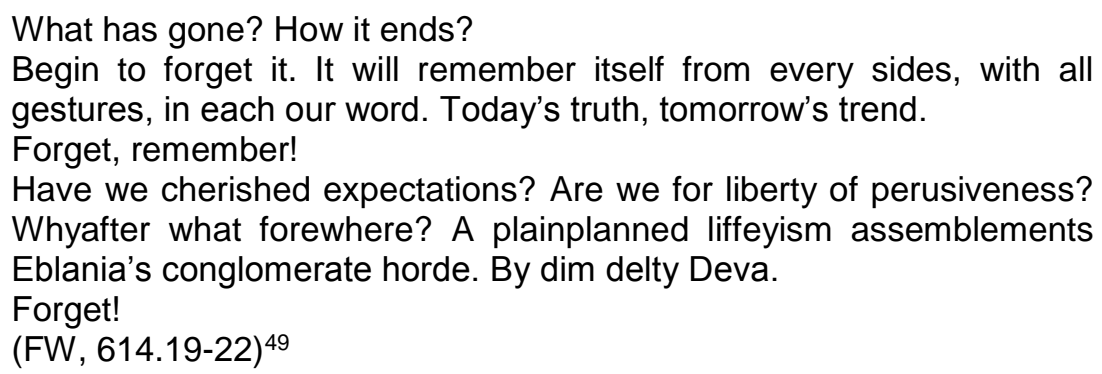

No livro XI de suas Confissões (398 d.C.; 1987), Agostinho de Hipona reiterou a supremacia do presente ao afirmar a definição da (anti)temporalidade do eterno: "Na eternidade, nada passa, tudo é presente, ao passo que o tempo nunca é todo presente" (AGOSTINHO, 1987: 216). Períodos anteriores à criação divina recaem nessa problemática: "Porém, se antes da criação do céu e da terra não havia tempo, para que perguntar o que fazíeis então? Não podia haver 'então' onde não havia tempo" (Ibid., 1987: 217). Agostinho define a temporalidade a partir do presente, pois define o passado e o futuro por contraste e diferenciação; no entanto, Agostinho também traz a possibilidade do nãotempo e desloca o centro, ainda, do aparecimento/presença para o desaparecimento/ausência:

49 "O que se passou? Como há de terminar?

Começa a deslembrá-lo. Isso há de se remembrar de todos os lados, com todos os gestos, em cada uma de nossas palavras. Verdade hoje verso amanhã.

Desmembra, remembra!

Afagamos expectativa? Somos pela liberdade de investigação? Por que após o que é prassempre? Plenos planos de liffeyismo nas assembleias da horda conglomerada de Eblânia. Junto à turva dialética Diva.

Olovidiar." 
Quanto ao presente, se fosse sempre presente, já não seria tempo, mas eternidade. Mas se o presente, para ser tempo, tem necessariamente de passar para o pretérito, como podemos afirmar que ele existe, se a causa da sua existência é a mesma pela qual deixará de existir? Para que digamos que o tempo verdadeiramente existe, porque tende a não ser? (Ibid., p. 218).

Sendo uma abordagem não necessariamente do âmbito da investigação ontológica, Agostinho não busca a definição do tempo em si, pois volta-se à percepção. Isso se evidencia quando ele faz, efetivamente, a pergunta específica do tempo:

O que é, por conseguinte, o tempo? Se ninguém mo perguntar, eu sei; se o quiser explicar a quem me fizer a pergunta, já não sei. Porém, atrevo-me a declarar, sem receio de contestação, que, se nada sobreviesse, não haveria tempo futuro, e se agora nada houvesse, não existiria o tempo presente. (Id.)

Sua resposta deixa claro que saber o que é o tempo significa aí estar na condição de um ser que pode vivê-lo, percebendo suas mudanças. Agostinho diz os termos "tempo futuro" e "tempo presente", uma divisão que evidencia o fato de a sua pergunta pelo ser do tempo não buscar, de fato, uma investigação mais que perceptiva da temporalidade, lidando com sua vivência em vez de buscar sua definição ou conceituação. Talvez fosse a resposta mais indicada para o tempo do Finnegans wake: sem questionamentos, ao nos depararmos, sabemos algo sobre, pois vivemos a temporalidade do texto; já se tivermos de explicá-la é que os problemas se iniciam...

A relação entre uma consciência de temporalidade e a dificuldade de bem compreender o tempo também se mostra textualmente. O capítulo 13, que Campbell e Robinson denominam Shaun before the people ("Shaun diante do povo"), lembra Agostinho ou um diálogo socrático com a forma de perguntas e respostas, em que Shaun vai respondendo a quatorze perguntas, uma a uma. Com uma abertura no capítulo que se preocupa em situar as horas, o que abala o apego ao presente (além de esse apego existir no próprio método de 
questionamentos e réplicas imediatas) é a consciência de uma sombra ou algo de uma meia-noite que se aproxima: "Come not here! Black! Switch out!" (FW, 403.17) ${ }^{50}$. A consciência que, no caso, é a consciência de uma outra dimensão, através de medo e receio, abala o terreno temporal de bases fixas no tempo presente, ainda que o ciclo e o ricorso também afirmem essas bases.

O tempo do texto, caso coincida com o tempo da leitura - que o faz reviver como a execução da partitura faz com a composição musical -, é o presente puro da experiência. $O$ tempo narrativo - se deixarmos de lado, temporariamente, a concepção de Finnegans wake como livro que descarta a narrativa e desmantela seus elementos - poderia ser entendido, em uma primeira tentativa, de imediato, como tempo circular, dada a sua estrutura e a inspiração nas Idades da teoria de Giambattista Vico. Isso seria adequado para pensarmos a relação entre esse tempo presente da leitura e a dada circularidade textual - o que se faz em ciclo, sendo um eterno retorno, teria necessariamente de engendrar, por conseguinte, um eterno presente, no esteio do que afirma Agostinho, pois é a continuidade que desconhece início e fim, divisão que seccione ou corte o que tem por definição a fluidez. Isso leva à aporia de que fala Agostinho entre considerar que o ciclo engendra um presente supremo mas, por outro lado, se só houvesse presente, não haveria tempo, e sim eternidade.

No entanto, se o texto já não é em si cíclico e, como vimos com Derrida, tem seu centro deslocado e uma caracterização possivelmente elíptica - ainda que, em verdade, o ciclo, seja viquiano, seja joyciano, seja nietzschiano, não é simplesmente repetição pura e simples, mas sim retorno com diferenciação, isto é, não só passível como obrigatoriamente submetido a mudança e a renovação -, essa relação de presente se quebraria. A isso se relaciona intrinsecamente o fato de que o texto escritural, reinvocando Derrida, lida com o porvir, diferente do futuro. Essa outra qualidade temporal modifica toda a dinâmica textual, na medida em que o porvir é o tempo do acontecimento, daquilo que vem sem espera, que surge do vazio, da ausência; por outro lado, o texto que lida com futuro calculável, início-meio-fim e sequência narrativa é o que lida com a

50 "Não te quero, nero! Sombra, suma!" 
presença e a previsibilidade. Somente o porvir deixa rastros espectrais daquilo que não se previu - e é disso que todo a leitura do texto literário está inevitavelmente permeada.

Emmanuel Levinas, filósofo que compreende a história como escatológica, não como progressista e que afirma sua ética metafísica a partir da existência do Outro, tem compreensão temporal que pode nos ajudar a compreender a dificuldade de se enxergar uma sincronia no texto de Finnegans wake. Para Levinas, a tradição que supõe a existência do tempo de um eu está equivocada por desconsiderar o face a face, desconsiderar o Outro. Assim, uma sincronia, isto é, a assunção de um único presente, não passa, como tempo da subjetividade de um indivíduo, de mera presunção por entender o tempo objetivamente (por mais inicialmente contraditório que isso possa soar). Isso poderia ser resolvido pela adição do tempo diacrônico, que passa a existir na relação com o outro e instaura um tempo que eu, subjetividade individual, não vivi. Haveria uma disjunção anacrônica entre sincronia e diacronia, como princípio da descontinuidade, que provaria a impossibilidade de um tempo objetivo ou de uma compreensão objetiva do tempo, reduzindo isso a mera pretensão. A sincronia é uma temporalidade insular, enquanto a diacronia expandiria esse isolamento. A futuridade do futuro não vem como porvir, no meu horizonte, e não posso reduzir o tempo do Outro ao meu: o tempo do Outro é o Outro do meu tempo.

É a terceira categoria sobre a qual discorre Levinas na supracitada obra Autrement qu'être ou au-delà de l'essence, contudo, que mais nos interessa e que complementa fundamentalmente as noções expostas anteriormente. É somente no reconhecimento de que há, na verdade, muitos presentes, e de que nem mesmo o próprio eu, sendo um eu ordinário, detém o seu presente menos ainda seu passado reduzido a lembranças embaçadas e seu futuro incerto - que se poderia compreender verdadeiramente o tempo. Isso porque somente um eu ideal, ou melhor, o ser real, que dita o que o presente é, poderia ser premissa de sua existência e efetivamente deter ou reter o presente. $O$ reconhecimento dessa impossibilidade, aliado ao reconhecimento essencial de que existe o face a face, de que existe o Outro cujo tempo me é tão inapreensível 
quanto ele mesmo o é, haveria o reconhecimento de que sincronia e diacronia, portanto, são maneiras ainda defeituosas de se compreender o tempo para o humano. A terceira categoria fundamental que advém dessas reflexões é o tempo do anacronismo. Reconhecendo-se a existência de muitos presentes, o anacronismo reconhece ainda que o surgimento de um Outro abre não só o meu tempo para o dele/a, mas também há tempos de muitos outros de muitos tempos, mortos ou ainda por virem a nascer. O tempo consiste em uma relação com o que não pode ser assimilado, com aponta Levinas; não se trata de ter boa memória ou não, mesmo que suas limitações tenham importância nisso tudo, mas o central é a impossibilidade de que toda a dispersão do tempo pudesse se juntar em um só presente. Por isso, sincronia e diacronia são insuficientes para essa compreensão, enquanto o anacronismo respeita a existência das nuances variadas dos aspectos temporais da existência.

Essa compreensão levinasiana é, ao que nos parece, brilhantemente adequada para a compreensão do tempo no texto do Wake, justamente sendo uma obra que reúne simultaneamente mortos e vivos, remorrentes e ressuscitantes - e aqui se faz mister evocarmos o revenant de que fala, também, Derrida, evocando novamente o caráter espectral, de presençaausência simultânea e vinda inesperada, isto é, cuja chegada se faz somente no porvir, como o fantasma de um autor que retorna e se faz presente de alguma outra forma por meio de sua obra. O tempo como concebido por Giambattista Vico como paradigma não anula a pluralidade do anacronismo sobre o qual Emmanuel Levinas discorre; ao contrário, compreende-se que as Idades viquianas abarquem presentes diversos e não partam de uma consciência temporal única. Poderíamos falar em caotização, mas, em verdade, caotiza-se na medida em que se foge do linear, cronológico, sincrônico, uno, sem que a caracterização necessariamente se reduza de maneira específica a pura e simplesmente caos.

Na caracterização de onde reside Shem, o irmão que pode ser o alterego do artista (e até do próprio Joyce), onde convive com passado, morte, alteridades diversas, assim como na prisão, morte e ressurreição de Humphrey Chimpden Earwicker, pai de Shaun, Shem e Isobel e marido de Anna Livia, vemos essa 
fusão de vida e morte que não controla o tempo em fases imiscíveis. Shem está em meio a "fresh horrors from Hades" (FW, 183.35) ${ }^{51}$ e por "Tumult, son of thunder, self exiled in upon his ego, a nightlong a shaking betwixtween White or reddr hawrors, noondayterrorised to skin and bone by na ineluctable phantom" (FW, 184.6-9) ${ }^{52}$, trecho em que inevitavelmente nos lembramos da inelutável modalidade do visível de Ulysses, que aqui se transformou em fantasma como visível.

Interessante notar como o capítulo imediatamente posterior ao de Shem, que será o Anna Livia Plurabelle, em que lavadeiras confabulam sobre fatos e fofocas, termina com a noite caindo em cada vez mais escuridão e menos informação factual, menos visão clara, como se a cena fosse se apagando e perdendo a força a cada vez que se repete a palavra "night". Em meio a paranoias e sensação de adormecimento, "night" dá o tom de queda gradual — não como a queda monumental de Earwicker no primeiro fragmento, que também se repete pelo livro, mas uma quebra branda. Em vez de pontuar um momento, o efeito principal é, com "night", prosseguir evocando a escuridão e, ao mesmo tempo, mantendo-se progressivamente suspensos os ecos dessas conversas:

Dark hawks hear us. Night! Night! My ho head halls. I feel as heavy as yonder stone. Tell me of John or Shaun? Who were Shem and Shaun the living sons and daughters of? Night now! Tell me, tell me, tell me, elm! Night night! Telmetale of stem or stone. Beside the rivering waters of, hitherandthithering waters of. Night! (FW, 215.36-216.5) $)^{53}$

Sendo todo um livro da noite, como se coloca usualmente e como o próprio Joyce já pontuou em oposição a Ulysses, as misturas de escuridão, noite, quebra de fala e silêncio seriam naturalmente recorrentes. Ainda assim, elas acontecem de maneira especialmente controlada, em momentos cruciais e

\footnotetext{
${ }^{51}$ Na tradução de Donaldo Schüler (2003), "novos horrores do Hades".

52 "Tumulto, filho do trovão, auto-exilado no seu ego, tremores da noite inteira entre horrores brancos e rubros, aterrorizado ao meio-dia da pele aos ossos por um fantasma inelutável" (idem). 53 "Noturnos falcões nos escutam. Noite! Noite! Tomba a testa. Pende pesada qual pedra, aquela. Que me falas de John ou de Shaun? Shem e Shaun, viventes, filhos ou filhas foram de quem? A noite noita! Fala-me, fala-me, fala-me, carvelha! Noite noite! Conta-me contos de Stem ou Stone. Junto às rio-revantes águas de, correntes-e-recorrentes águas De. Noite!" (idem).
} 
específicos no Wake, como que desestabilizando a noção temporal de noite ou de uma noite, ou de noite como algo definido temporal e até espacialmente - em vez de partirem para o que seria uma caracterização temporal. A noite funciona como algo que subverte a inércia do tempo presente, sendo uma noite sem duração, reverberando ainda em uma série de evocações de "night" como se ela não estivesse presente, mas invadisse aos poucos à medida que o apelo acontece. A palavra "Night" caracteriza o indefinido em vez de definir (seja uma ou seja qualquer) noite específica.

Aquilo que não é definido pontualmente não pode, consequentemente, fazer parte de uma evolução temporal da ordem do linear, com cenas consecutivas que se somam sem se sobreporem, progredindo do passado para o futuro. Isso não deve necessariamente acontecer somente na hipótese da eternidade pura, como disse Agostinho a respeito do tempo presente que não tem passado e futuro como constrastes; o que retorna sempre em círculos pode, também, ter como corolários antes/agora/depois, ao mesmo tempo em que não teria início fundador/originário nem fim escatológico. Retornando a Autrement qu'être ou au-delà de l'essence, para caracterizar a oposição do anacronismo que reúne essas vozes e ausências-presentes em relação à ideia de linearidade que uma sincronia necessariamente contém, Emmanuel Levinas cita a tradição fenomenológica como caracterizadora da unidade de sincronia, que não considera a alteridade e a ética, citando Edmund Husserl. Com esse gancho esclarecedor, então, Levinas explica:

\footnotetext{
Chez Husserl, la conscience interne du temps, et la conscience tout court, se décrivent dans la temporalité de la sensation: "sentir, c'est là ce que nous tenons pour la conscience originaire du temps" et "la conscience n'est rien sans l'impression". Temps, impression sensible et conscience se conjuguent. (...) Parler conscience, c'est parler temps. (LEVINAS, 1978, pp. 56-57) 54
}

54 "Em Husserl, a consciência interna do tempo e a consciência em si se descrevem na temporalidade da sensação: "é no sentir que podemos ter a consciência originária do tempo" e "a consciência não é nada sem a impressão". Tempo, impressão sensível e consciência se conjugam. (...) Falar de consciência é falar de tempo." 
Emmanuel Levinas considera, então, uma temporalidade específica para a fenomenologia, que considera a consciência de um indivíduo como premissa para qualquer investigação; é essa temporalidade o que resulta em uma sincronia não atravessada pela alteridade. Ao contrário dessa concepção, Levinas descreve o "Anachronisme qui ateste une temporalité différente de celle

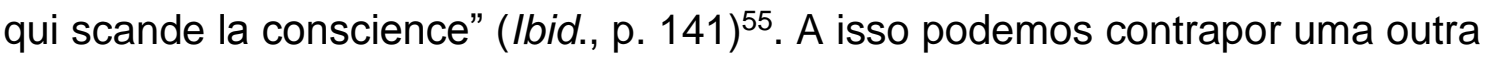
ponte com o Ser e tempo de Martin Heidegger: quanto ao aspecto do ente como "dentro do tempo", Heidegger interfere com o apontamento da historicidade como um modo-de-ser temporal do Dasein. Nessa abordagem, o tempo, ou o tempo presente também deixa de ser isolado pela experiência sincrônica individual:

\begin{abstract}
A determinação da historicidade é anterior ao que se chama de história (o acontecer de-história-universal). Historicidade significa a constituição-de-ser do "gestar-se" do Dasein como tal, sobre cujo fundamento é unicamente possível algo assim como a "história universal" e o histórico a ela pertencente. O Dasein, em seu ser factual, é cada vez como já era e "o que" já era. Expressamente ou não, ele é seu passado. E não só no sentido de que seu passado como que desliza "atrás" dele, possuindo ele o passado como se fosse uma propriedade subsistente que por vezes volta a ter efeito sobre ele. (HEIDEGGER, 2012, p. 81)
\end{abstract}

Assim, o privilégio do presente que citamos anteriormente como foi apontado por Derrida, em referência, ainda, a Aristóteles, perde seu aspecto de vivência possível como sendo algo puramente no/do instante, algo complementando pelo que acrescenta Heidegger no excerto acima de Ser e tempo: o passado integra o presente (como o revenant) e não se encerra atrás dele, ou antes dele, intacto e passível de retorno somente por rememoração/recordação (entendida como espécie de movimento de lembrança feito intencionalmente). Uma suposta divisão temporal entre as fases, então, que separe o passado do presente, não é possível considerando o passado como essa historicidade que revém. O presente, no entanto, ainda é o tempo central

55 "Anacronismo que atesta uma temporalidade diferente daquela que mede a consciência." 
da leitura. Em Escritura do retorno: Mallarmé, Joyce e o meta-signo, Piero Eyben relaciona o que propõe ser o resultado da empreitada de Joyce - "destruição do signo" - com uma "agoridade da letra”: “(...) a experiência joyceana da destruição do signo deve ser compreendida como um limite da experiência do agora. (...) a significância é sua única resposta" (EYBEN, 2012, pp. 650-651). A marca do presente não é pura, nem pode ser destilada em uma fase temporal solitária:

\begin{abstract}
Nessa des-fundação de toda origem podemos ver a própria cena da presença enquanto elemento presente que se relaciona com outra coisa que não ele mesmo, guardando em si a marca do elemento passado e deixando-se já moldar pela marca de sua relação com o elemento futuro. (...) Todo rastro é sem presente e sem arquia, uma vez que se constrói como a síntese de "marcas" que se estabelecem em um espaçamento (devir-tempo do espaço). (Ibid., p. 651)
\end{abstract}

No capítulo 9 do livro II, livro das crianças, temos uma espécie de encenação teatral. São situados personagens e, ainda, o tempo: "Time: the pressant" (FW, 221.17) ${ }^{56}$. O presente mais parece um verbo no gerúndio, ou uma forma nominal de um verbo, indicando uma ação que remete ao presente movimentado, em movimento, não inerte e recortado. Mesmo na ficção dentro da ficção é o tempo dinâmico que se faz. Nas palavras do tradutor do Wake, Donaldo Schüler: "O fixo dissolve-se no que flui. Cultura do presente? Qual, se tudo se embala em vir-a-ser?" (2003, p. 96). Aqui, o presente não se faz em eternidade pura e cíclica, mas no porvir que se instala: a expectativa do que pode vir é diferente da futuridade do futuro certo, previsto - e, portanto, calcado no tempo presente que o planeja. O porvir, ao contrário, faz do presente uma pura expectância, naquilo que se tece como limiar de ausente e presente, por ser a expectativa do que não se pode, de fato, esperar. Se o futuro no escapa pelos dedos e o passado resta, o presente só pode ser uma contaminação geral dessa fludez de ricorso torrencial.

56 “Tempo: o pressante” (tradução de Donaldo Schüler, 2003). 
Finnegans wake muito mais questiona do que afirma seu próprio tempo em vias explícitas. Mesmo no fim do livro, quando se encaminharia para um fechamento e, portanto, para o término, a sutura, a closure, Anna Livia nos encaminha para o desembocar do rio - no mar, no retorno ao seu curso, no ricorso, na fluidez que é seu destino em repetição, mas repetição em sempre inovação - que não se situa com precisão temporal. O livro IV se abre com "Sandhyas! Sandyas! Sandhyas!" (FW, 593,1). Segundo Donaldo Schüler, há aí referência a Sanctus! Sanctus! Sanctus! (que aparece também em "Xanthos! Xanthos! Xanthos!" - FW, 235.9) e a sandhi, palavra do sânscrito que significa paz ou crepúsculo. Muito mais pode ser dito sobre essa abertura: além da saudação latina religiosa, o que vem do sânscrito pesa sua presença em um significado riquíssimo.

O termo do sânscrito sandhyā, como pode ser transliterado de सन्धया, pode significar união ao mesmo tempo em que é diferenciação, divisão; é o crepúsculo ou o nascer do sol, ao mesmo tempo em que é a escuridão da madrugada ou da manhã; é transição, união e impossibilidade de união de dois opostos, claro e escuro, dia e noite, começo e fim. É justamente a articulação entre aquele instante do meio que não se pode chamar somente de início, nem somente de fim: é ambos ao mesmo tempo. É o momento de reinício e, portanto, de redenção e renovação, assim como de fim, de enterrar, de sumir, de não ver. Tem-se um dia todo pela frente; concomitantemente, porém, não se tem mais um dia, que acaba de findar. A palavra é absolutamente adequada: indica tanto início, quanto fim, e ainda significa intervalo, entremeio, fase que antecede uma e sucede outra. As relações possíveis são muitas. Lidar com a morte, por exemplo, é lidar com algo que se inicia povoado por uma ausência. Luto se faz em elipse. Não se supera um passado, mas se convive com ele até que ele povoe o presente de maneira cada vez mais translúcida e menos materialmente formada e visível como o presente pode nos parecer na imediaticidade fenomênica do instante. 
Direcionando-se ao fim, no mesmo livro, dotado de um só capítulo, Anna Livia diz: "Like almost now. How?" (FW, 626.29-30)57. Em inglês, pode-se compreender "like almost now" como o mesmo que "como quase agora", de maneira que eseja sendo indicado ou referenciado um "agora" não pontual ou não pontuado, talvez fluido por ser indefinível; o agora o é quase à medida que o presente escapa. Logo ela anuncia mais contundentemente a substituição de gerações, com a passagem do tempo:

\begin{abstract}
And can it be it's nnow fforvell? Illas! I wisht I had better glances to peer to you through this baylight's growing. But you're changing, alcoosha, you're changing from me, I can feel. Or is it me is? I'm getting mixed. Brightening up and tightening down. Yes, you're changing, sonhusband, and you're turning, I can feel you, for a daughterwife from the hills again. (FW, 626.33-36; 627.1-3). ${ }^{58}$
\end{abstract}

Anna Livia dá lugar à filha, Isobel, na ordem natural familoar, e aos filhos Shem e Shaun, assim como seu marido será substituído. O espaço das memórias ("And let her rain now if she likes. Gently or strongly as she likes. Anyway let her rain now if she likes. I done my best when I was let" --- FW, 627.11$13^{59}$ ). Isobel, Isabel, Issy que é também Nuvoletta, a nuvem que chove e preenche o rio, mas é formada a partir dele; Anna Livia abre espaço ao protagonismo da filha que a sucede no fluir e o ricorso é fechado no ciclo natural que metaforiza o das relações familiares.

O fluir-ricorso é mais que o fechamento do ciclo que realiza o movimento circular e repete o mesmo percurso em cadeia: é primordialmente a impossibilidade de diferir o fechamento da (re)abertura, em momento-ínterim entre a morte e a vida que unem em Finnegans wake o anacronismo daquilo que não se unitariza em tempo vivido por uma consciência à diferenciação que se faz com o ciclo que se modifica com as gerações, com as reverberações do que

57 "Quase como agora. Como?", na tradução de Schüler (2003).

58 "Será que é agora nnoss'último adeus? Illás! Oxalá eu tivesse melhores vistas para te contemplar à luz alvorecente da Bahia. Mas tu já não bates, meupulso, tu te abates de mim, bem o sinto. Ou isto é eu é? Estou confusa. Illo minando-me estou me dilu indo. Sim, estás mudando, filhemarido, posso sentir-te, para uma filhesposa dos montes outravez" (idem).

59 "Chovela agora, se é isso que adora. Chovisco ou trombada, como lhe agrada. Chova, no entanto, visto que vinda é minh'hora. Dei meu recado enquanto me foi dado" (idem). 
se vão ainda ecoando no futuro, com as singularidades. O desmantelamento desse presente puro o transforma em algo contaminado de porvir, ainda permeado do rastro do passado e acima de tudo indefinível como tempo palpável a não ser se emoldurado em conjunturas ficcionalizantes.

A continuidade é assegurada por meio da evocação de Anna Livia dos que a seguirão, apelo e chamamento que fazem a anunciação da chuva de Nuvoletta/Isobel. A mãe, de certa maneira dando a sua permissão, mas sendo antes forçada pelas circunstâncias do tempo que não para, dá lugar sem desaparecer por completo. A temporalidade essencial de todo o Wake é a da substituição que não substitui, pois mantém; o que perpetua mas também aniquila, da mesma maneira como o crepúsculo pode ser confundido com 0 nascer do Sol. 
CONSIDERAÇõES FINAIS 
Foi reafirmado o quanto defendemos o afastamento da compreensão una de literatura, seja com Finnegans wake, seja com qualquer outra obra escritural. Isso pode ser não uma saída sagaz que se esquivaria de questionamentos importantes sobre a estrutura e os desdobramentos semânticos do texto intrincado de Joyce, mas sim uma abertura ao perigoso desfrutar dos problemas. Em vez de uma estratégia, uma compreensão de que é da incompreensão que podem surgir boas leituras, inclusive acadêmicas. Para partir da incompreensão, aí, sim, nada mais adequado, desafiador e divertido do que o Finnegans wake. Em vez de resolver os problemas, responder os questionamentos e fechar o livro com a certeza veemente de que se compreendeu e já se pode dizer "terminei!", abre-se o livro novamente. E novamente. E incessantemente. 
Isso não é necessariamente preocupante: restaria, talvez, saber se o problema é conosco, com o texto ou se consiste na impossível acomodação a uma teoria literária que demanda explicações que não podemos dar. Ou até possamos, talvez, mas necessariamente optando por um caminho que reduz a uma interpretação - um trabalho hermenêutico que busca o dogma ao invés de lidar, por que não, com mais de uma possibilidade simultânea. Foi instaurada a herança de lidar com a literatura como lidamos com as escrituras sagradas, que podem oferecer uma poética que abre para a fruição mas, acima de tudo, pautam ensinamentos, que devem ser objetivos pelo bem do funcionamento de um sistema externo ao texto. Literatura, porém, não é o que diremos dela. Como os guias para o Finnegans wake dizem, em geral, desculpando-se antecipadamente: isto - esta dissertação, esta pesquisa - não pretende abarcar uma leitura totalizadora. Talvez já fosse a hora de isso não precisar ser dito apenas para o Wake, mas sobre qualquer livro de literatura. É claro que há uma dificuldade em abrirmos mão do status de "autoridade em", mas a literatura precisa dessa distância. $O$ cuidado científico dela é esse.

Considerando, contudo, as demandas de ensino básico de literatura nas escolas, por exemplo, ou mesmo as demandas acadêmicas, que exigem porventura uma produtividade que se possa comprovar: como acomodar o Finnegans wake ao que a teoria ou a leitura hermenêutica teorizada demandam? Aliás, como - e por que - acomodar qualquer obra literária a uma sistematização que esquematiza seus elementos de maneira engessada? 0 ponto sequer é uma recusa não mais tão inovadora ou a reforma do sistema, de qualquer teoria, de qualquer aporte, mas o entendimento claro de como isso afeta uma leitura e da hierarquia entre essas instâncias, se determina o que um livro pode ter para funcionar e o que seu gênero permite que se pressuponha a seu respeito. Nesse sentido, o questionamento do tempo, tão filosófico e abstrato, tornar-se-ia prático quando pensássemos no impacto das concepções de história da literatura, cânone, sistema. O tempo feito em uma diacronia das obras-primas, o tempo sobre o qual repousam as obras que importam e o tempo do ostracismo das relegadas à margem. Esse tempo nos importa somente para ser questionado. 
O manual tradicional e didático Teoria literária, de Hênio Tavares, traz o excerto "O objeto da ciência da literatura", de Fundamentos da interpretação e da análise literária (1948), de Wolfgang Kayser, que, por sua vez, cita a separação severa entre poesia e literatura, feita pelo italiano Benedetto Croce. A poesia estaria fora da literatura. Não seria, no entanto, facilmente classificada pelos critérios formais de versos e estrofes, mas sim um termo valorativo, qualitativo. Dessa maneira, até mesmo Os Lusíadas ficariam de fora de Poesia (Dichtung) nessa classificação, e "dela separado por um abismo" (KAYSER in TAVARES, 2002, p. 42). Citamos essa curiosa e incisiva classificação em tentativa de delimitar o que é digno de ser apreciado como Poesia e o que não é para apontar a ironia: se essa classificação aparentemente excessivamente limitante não pressupõe que Poesia seja tão somente forma oposta à prosa, talvez Finnegans wake entrasse para o rol da Poesia e, de fora da literatura, tivesse sua qualidade canonicamente reconhecida.

No texto "Che cos'è la poesia?", Jacques Derrida toma outros rumos na problematização do que é literatura e do que é poesia. A figura do ouriço surge para apontar uma experiência que jamais é inofensiva, de maneira que uma relação com o texto literário é uma relação da qual nunca se pode sair incólume. Não se lê sem apelo, e aqui evocamos novamente a carta mamafesta de Anna Livia como momento condensador desse apelo, ou sua posterior análise no capítulo 6, em que o método de perguntas e respostas lança o questionamento e a demanda inevitavelmente também ao leitor, ou mesmo o de Shaun iniciando o capítulo 13 dizendo "Hark! (...) Hork!" (FW, 403.1/3)60. Em Escritura do retorno, assinala-se que

Derrida inicia sua problemática (...) com a renúncia, com certo desligamento do saber. Saber, em termos de poemática, é saber renunciar o que se sabe. Nesse sentido, a poesia exige outra forma de conhecer que, talvez, seria aquela do ditado que se pode "ver como ditado". A poesia não é uma aparência - ou ainda não é uma "parecença", sua ação é daquilo que se vê fora do parecido, mas dentro de uma representabilidade que é sua própria reflexão. (EYBEN, 2012, p. 259)

60 “Escuta! (...) Escucha!” (2003). 
Como dissemos, uma necessidade de autenticação do texto por um sistema literário que forja sua história e seu cânone não nos preocupa (o apego ao sistema que sobrevive e mutila experiências literárias, talvez, sim). Também citado por Hênio Tavares, diz Afrânio Peixoto: "O gênero das obras-primas, em geral, é pessoal e privativo delas" (PEIXOTO in TAVARES, 2002, p. 158), exemplificando sua afirmação citando Rabelais, Quixote, Montesquieu. Mesmo que fosse relativamente possível de se definirem, as classificações ainda assim permanecem dispensáveis no lançar-se ao texto e, lançando-nos, deparamo-nos com o segredo indizível próprio do escritural.

Se indizível, evidentemente, também inclassificável, sem que isso seja um defeito e distante de ser uma abertura a qualquer coisa, a uma leitura tão frouxa que fosse vazia ou esvaziada por uma relativização desmedida. Finnegans wake é aberto e amplo, mas cheio e povoado de caminhos, sem que tenha rédeas apertadas demais para direcionar uma só leitura ou uma rota preferencial, como todo texto escritural tem entradas diversas e a literatura não se faz em hierarquias através das quais nos prestamos a buscar a verdade do texto, que estará no fim do caminho percorrido. Se houvesse uma linha reta a ser seguida, ou mesmo um labirinto desse tipo, não haveria segredo no texto - ou haveria um segredo que se perderia sendo revelado e, nesse caso, deixaria de existir, o que desmoronaria o entendimento de segredo do texto literário como aquilo que se mantém secreto, mesmo após repetidas leituras e mergulhos no texto, por mais profundos que possam ser. Em Gêneses, genealogias, gêneros e o gênio, em que fala de Hélène Cixous, Jacques Derrida assevera sobre o segredo da literatura:

Lá se encontra, como segredo da literatura, o poder infinito de manter indecidível e portanto irrevelável o segredo do que ela diz, ela, a literatura, ou ela, Cixous (...) O segredo da literatura é, pois, o próprio segredo. É o lugar secreto onde ela se institui como a possibilidade mesma do segredo, o lugar de sua gênese ou de sua genealogia própria. Isto é verdade em todos os gêneros literários. (DERRIDA, 2005, p. 22) 
Também pertinente é o que, nesse mesmo lugar, Derrida diz a respeito, ainda, de Cixous, e de uma escrita que desperta do onírico: "palavra escrita ao despertar, endereçada e destinada ao despertar. Como se o despertar, ao sair do sonho, em seu wake, estivesse ainda na vigília do sonho" (Ibid., p. 45) e "o próprio sonho é o que interrompe o sono. O sonho desperta. O sonho vela e ele vela a endereçar injunções inflexíveis à vigília" (Ibid., p. 43). Ainda que essas palavras de Derrida não sejam explícita e diretamente sobre o Wake, nelas, o sonho não é anestesia, e no Wake também não; ocorre até o oposto: o sonho se mescla ao despertar e à ressureição. O sonho, para Derrida e para Joyce, em nada inerte e também nada linear como a vida real, é o terreno das maiores e multiplicadas possibilidades, bem como da atividade de certa maneira caótica e do tempo do anacronismo, do entrecruzamento de alteridades e dos ecos polifônicos.

Encaminhamos este fim - que certamente nos faz retornar, retornar ao texto, ao Wake, a Joyce, à literatura - lembrando que a temporalidade da leitura é a materialidade do tempo da literatura, é o tempo efetivamente vivido na ressureição do texto, mas é, também, temporalidade significativamente esquiva a tentativas de definição. O presente da (de uma e de qualquer) leitura é constantemente desestabilizado (e em Wake isso se faz sem misericórdia) e nunca se tem uma base fixa na qual se agarrar, a não ser o próprio abismo escritural.

\begin{abstract}
Em termos joyceanos, não temos um rio de significado, mas sim o rio como rasura da chuva que é, em si, uma forma de condução dos significantes como respostas - réplicas - ainda textuais. O sujeito que lê também é perdido, rasurado, pois sua referência deve ater-se apenas à escritura, única satisfação exigida. O sujeito, cavado na aparência, é soterrado pelo barranco chuvoso dos sintagmas deslocados. (EYBEN, 2012, pp. 258-259)
\end{abstract}

Em termos de temporalidade textual, buscamos entender relações diversas além da temporalidade da leitura ou da literatura lida/vivida; entraram aqui o tempo do ausente, do morto que se faz espectro (além do que acontece com HCE, o próprio morto ressuscitado, como Tim Finnegan o é na balada irlandesa a que Joyce se remete), presença e ausência como dispositivos de 
uma temporalidade do anacronismo, presenças que se fazem também no chamamento, no apelo e na demanda. A estrutura paradigmática viquiana oferece subsídios já trabalhados, mas o Wake, com seu caráter onírico, acoberta uma série de cruzamentos e nós que, se vistos mais de perto, enriquecem a leitura. Pode ser que análises de textos, de escritura, de literatura, em vez do senso comum de que sejam elucidativas e iluminadoras, sejam não somente dispensáveis, mas também excessivas, produzindo mesmo interferências, tornando a já difícil leitura por si só ainda mais barroca e excessivamente pesada de detalhes a serem enxergados. Caminhos mais interessantes, por conseguinte, seriam os da teorização que interesse por si só, que possam acompanhar a leitura do Wake sem causar ruídos nela, tampouco pretendendo clarificá-la, em objetivação pretensiosa.

Finnegans wake se estabelece no entremeio da verdadeira oposição entre circularidade e linearidade, em que o círculo pode ser pensado se percorrido nos moldes da demeure nomade derridiana, e não em ciclos de revisitação. Se tomarmos o Wake a partir do tempo mensurado, que se insere no caráter circular do sentido homogêneo e infinito, teremos de pensá-lo, sublinhe-se, em seu caráter precisamente literário, de forma distinta de pensarmos essa mesma obra a partir do tempo de simultaneidade, que considere a estrutura circular sem redundância, sem repetição e sem divisões de linearidade. 


\section{BIBLIOGRAFIA}

ABBAGNANO, Nicola. Dicionário de Filosofia. São Paulo: Martins Fontes, 2014.

ACOSTA, Maria Isabel Cruz. The discourse of excesso: the latin american neobaroque and James Joyce (dissertation). Michigan: University Microfilms International, 1984.

AGOSTINHO, S. Confissões; De magistro. Trad. Angelo Ricci. São Paulo: Nova Cultural, 1987.

AMARANTE, Dirce Waltrick do. Para ler o Finnegans wake de James Joyce. São Paulo: Iluminuras, 2009.

ARISTÓTELES. Poética. Tradução de Eudoro de Sousa. Imprensa Nacional Casa da Moeda, 2003.

Paulo: Unesp, 2013.

Da interpretação. José Veríssimo Teixeira da Mata. São

BAKHTIN, Mikhail. A cultura popular na ldade Média e no Renascimento: o contexto de François Rabelais. Tradução de Yara Frateschi. São Paulo: Hucitec: Brasília: Editora da Universidade de Brasília, 2010.

- Para uma filosofia do ato responsável. Tradução de

Valdemir Miotello e Carlos Alberto Faraco. São Carlos (SP): Pedro e João Editores, 2010.

Paulo: Martins Fontes, 2011.

Estética da criação verbal. Tradução de Paulo Bezerra. São 
BARTHES, Roland. Image, music, text. New York: Hill and wang, 1977. . O prazer do texto. São Paulo: Editora Perspectiva, 2008.

BECKETT, Samuel et al. Our exagmination round his factification for incamination of Work in progress. Paris: Shakespeare and company, 1929.

BENJAMIN, Walter. A tarefa do tradutor: quatro traduções para o português. Org. Lucia Castello Branco. Belo Horizonte: Fale/UFMG, 2008.

BLANCHOT, Maurice. L'espace litteraire. Paris: Gallimard, 2010. . Uma voz vinda de outro lugar. Rio de Janeiro: Editora Rocco, 2011. . A conversa infinita 2: a experiência limite. São Paulo: Editora Escuta, 2007. . A conversa infinita 3: a ausência de livro. São Paulo: Editora Escuta, 2010.

BURGESS, Anthony. Rejoice. New York: W. W. Norton \& Company; Pages Stained edition, 1968.

. Joysprick: an introduction to the language of James Joyce. London: Andre Deutsch Limited, 1973.

A shorter Finnegans wake. Edited by Anthony Burgess. New York: Viking adult, 1967/8.

BUTOR, Michel; SVEVO, Italo; ECO, Umberto; POUND, Ezra; ELLMANN, Richard; VAN LAERE, François. Joyce e o romance moderno. Trad. T. C. Netto. São Paulo: Editora Documentos, 1969.

BUZZI, Arcângelo R. Introdução ao pensar: o ser, o conhecimento, a linguagem. 25aㅡ edição. Petrópolis: Editora Vozes, 1998.

COMPAGNON, Antoine. O demônio da teoria: literatura e senso comum. Tradução de Cleonice Paes Barreto Mourão e Consuelo Fortes Santiago. Belo Horizonte: Editora UFMG, 2010.

CAMPBELL, Joseph; ROBINSON, Henry Morton. A skeleton key to Finnegans wake. $2^{\text {nd }}$ edition. New York: New world library, 2013.

. "Introdução a um assunto estranho" in CAMPOS, Augusto de; CAMPOS, Haroldo de. Panaroma do Finnegans wake. São Paulo: Perspectiva, 2001.

CAMPOS, Augusto de; CAMPOS, Haroldo de. Panaroma do Finnegans wake. São Paulo: Perspectiva, 2001. 
CAMPOS, Haroldo de. Deus e o Diabo no Fausto de Goethe. São Paulo: Perspectiva, 2008.

. Reoperação do texto. São Paulo: Perspectiva, 2013.

. Metalinguagem e outras metas. São Paulo: Perspectiva,

2010.

- Teoria da poesia concreta: textos críticos e manifestos 1950-1960. Cotia: Ateliê editorial, (1965) 2006.

CERBONE, David R. Fenomenologia. Petrópolis: Editoria Vozes, 2013.

CLIETT, Bill Cole. A Finnegans wake lextionary. Createspace pub, 2011.

COELHO, Eduardo Prado. Os universos da crítica: paradigmas nos estudos literários. Lisboa: Ed. 70, 1987.

DEANE, Seamus. "Introduction" In: Finnegans wake. London: Penguin classics, 2000.

DE MAN, Paul. Alegorias da leitura: a linguagem figurada em Rousseau, Nietzsche, Rilke e Proust. Tradução de Lenita R. Esteves. Rio de Janeiro: Imago, 1996.

DELEUZE, Gilles. Lógica do sentido. São Paulo: Perspectiva, 2011.

. Crítica e clínica. Trad. Peter Pal Pelbart. São Paulo: Editora

34, 1997.

O que é a filosofia? Trad. Bento Prado Jr. E Alberto Alonso Muñoz. São Paulo: Editora 34, 2013.

DENNING, Robert H. (org.). James Joyce. Vol. Il (1928-41). The critical heritage series. London: Routledge Kegan \& Paul, 1997.

DERRIDA, Jacques. Papel-máquina. Tradução de Evandro Nascimento. São Paulo: Estação Liberdade, 2004. . La dissémination. Paris: Éditions du seuil, 1972.

Chicago University Press, 1984.

Margins of philosophy. Translated by Alan Bass. Chicago: . Acts of literature. New York: Routledge, 1991.

. "Che cos'è la poesia?" in Points de suspension. Paris: Galilée,

1992.

- Gêneses, genealogias, gêneros e o gênio. Trad. Eliane Lisboa. Porto Alegre: Sulina, 2005. 
. The gift of death and Literature in secret. Trad. David Wills. Chicago: The University of Chicago Press, 2008.

- A escritura e a diferença. São Paulo: Editora Perspectiva,

2009.

- Gramatologia. Trad. Renato Janine Ribeiro. São Paulo: Editora Perspectiva, 2008. . La vérité en peinture. Paris: Flammarion, 2010. . Adeus a Emmanuel Levinas. São Paulo: Editora Perspectiva,

2004. Aporias. Stanford: Stanford University, 1994. . Cartão-postal. Rio de Janeiro: Civilização brasileira, 2007. . "Duas palavras por Joyce" in NESTROVSKI, Arthur. Riverrun: ensaios sobre James Joyce. Rio de Janeiro: Imago, 1992.

ECO, Umberto. Obra aberta: forma e indeterminação nas poéticas contemporâneas. São Paulo: Perspectiva, 1988.

Harvard University Press, 1989.

The open work. Translated by Anna Cancogni. Cambridge:

ELLMANN, Richard. Four dubliners. New York: George Baziller, 1988. . James Joyce. Tradução Lya Luft. São Paulo: Editora Globo, 1989. Ao longo do riocorrente. Trad. Denise Bottmann. São Paulo: Companhia das Letras, 1991.

ESTEVES, Lenita. A (im)possível tradução de Finnegans wake: uma observação psicanalítica. Tese de doutoramento pela Pontifícia Universidade Católica de São Paulo, 1999.

EYBEN, Piero. Escritura do retorno: Mallarmé, Joyce e meta-signo. Vinhedo: Editora Horizonte, 2012.

FARGNOLI, A. Nicholas; GILLESPIE, Michael Patrick. Critical companion to James Joyce: a literary reference to his life and work. New York: Facts on file, 2006.

FELMAN, Shoshana. La folie et la chose littéraire. Paris: Seuil, 1978.

FLANNER, Janet. Paris was yesterday. Reprint edition. San Diego: Mariner Books, (1972) 1988. 
FOUCAULT, Michel. Les mots et les choses. Paris: Gallimard, 1990.

FRYE, Northrop. O Código dos códigos: a Bíblia e a literatura. Tradução de Flávio Aguiar. São Paulo: Editora Boitempo, 2006.

GALINDO, Caetano. "The Finnecies of music wed poetry: A música e o Finnegans Wake" in Sciencia Traductionis, n. 8, 2010.

GILBERT, Stuart. James Joyce’s Ulysses: a study. London: Vintage, 1955.

GUILHAUMOU, Jacques. Linguística e história: percursos analíticos de acontecimentos discursivos. Coordenação e organização da tradução Roberto Leiser Baronas e Fábio Cesar Montanheiro. São Carlos: Pedro e João Editores, 2009.

HALFORD, Macy. Books and their makers: Sylvia Beach and James Joyce. The New Yorker, 05 de março de 2010 <Em: http://www.newyorker.com/books/pageturner/books-and-their-makers-sylvia-beach-and-james-joyce, acesso em 16 de agosto de 2014.>

HEIDEGGER, Martin. Ser e tempo. Tradução, organização, nota prévia, anexos e notas de Fausto Castilho. Edição bilíngue. Campinas: Editora da Unicamp; Petrópolis: Editora Vozes, 2012.

- A caminho da linguagem. Tradução de Marcia Sá Cavalcante Schuback. Bragança Paulisa: Editora Universitária São Francisco; Petrópolis: Editora Vozes, 2011.

HODGE, Joanna. Derrida on time. New York: Taylor\&Francis USA, 2010.

JASPERS, Karl. Introdução ao pensamento filosófico. Tradução de Leonidas Hegenberg e Octanny Silveira da Mota. São Paulo: Cultrix, 2011.

JOYCE, James. Finnegans wake. Introdução, versão e notas de Donaldo Schüler; desenhos de Lena Bergstein. Cotia, São Paulo: Ateliê Editorial, 2004.

. Finnegans wake. London: Penguin classics, 2000.

- De santos e sábios: escritos estéticos e políticos. Org. Sérgio Medeiros e Dirce Waltrick do Amarante (trad. The critical writings). São Paulo: Iluminuras, 2012.

Cartas a Nora. Org. e trad. Sérgio Medeiros e Dirce Waltrick do Amarante. São Paulo: Iluminuras, 2012.

. Epifanias. Trad. Piero Eyben. São Paulo: Iluminuras, 2012.

. Ulysses. New York: Penguin classics, 2010. 
$\overline{\text { das Letras, } 2012 .}$

Ulysses. Trad. Caetano W. Galindo. São Paulo: Companhia

. Finn's Hotel. Trad. Caetano W. Galindo. São Paulo: Companhia das Letras, 2014.

KITCHER, Philip. Joyce's kaleidoscope: an invitation to Finnegans wake. New York: Oxford USA Trade, 2007.

LAROUSSE. Nouveau dictionnaire de français. Paris: Larousse fr, 2006.

LEVIN, Harry. A critical introduction to James Joyce. Connecticut: New directions, 1941.

LEVINAS, Emmanuel. Autrement qu'être ou au-delà de l'essence. Paris: Le livre de poche, (1974) 1978.

. Da existência ao existente. Trad. Paul Albert Simon, Ligia

Maria de Castro Simon. Campinas: Papirus, 1998.

. Totalité et infini Paris: LGF, (1961) 1990.

Nijhoff, 1979.

. Totality and infinity. Trad. Alphonso Lingis. Boston: Martinus

LITZ, Walton A. The art of James Joyce: method and design in Ulysses and Finnegans wake. London: Oxford University Press, 1961.

MANDIL, Ram. O efeito da letra: Lacan leitor de Joyce. Belo Horizonte: Contra capa livraria/Faculdade de Letras UFMG, 2003.

MERLEAU-PONTY, Maurice. Phénomenologie de la perception. Paris: Gallimard, 1976.

MILESI, Laurent. James Joyce and the difference of language. Cambridge: Cambridge University Press, 2003.

MOISÉS, Massaud. A análise literária. 1a edição. São Paulo: Editora Cultrix, 1969.

MCHUGH, Roland. Annotations to Finnegans wake. Baltimore: Johns Hopkins University Press, 2006.

NASSER, Eduardo. "O tempo em Platão: os meandros da leitura heideggeriana" in: Hypnos, Ano 11, número 17, p. 112-126.

NESTROVSKI, Arthur (org.). Riverrun: ensaios sobre James Joyce. Rio de Janeiro: Imago, 1992. 
NORRIS, Margot. The decentered universe of Finnegans Wake - A structuralist analysis. London: The John Hopkins University Press, 1988.

PARMÊNIDES. Da natureza. Trad. José Gabriel Trindade Santos. São Paulo: Loyola, 2002.

PATELL, Shireen R. K. "Untranslatable you”. In Cardozo Law Review. Vol 27:2. New York, 2005.

PELBART, Peter Pál. O tempo não-reconciliado: imagens de tempo em Deleuze. São Paulo: Perspectiva, 1998.

READ, Forrest. Pound/Joyce:The Letters of Ezra Pound to James Joyce. New York: New directions, 1970.

RICOEUR, Paul. A memória, a história, o esquecimento. Tradução Alain François et al. Campinas: Editora da Unicamp, 2007.

Martins Fontes, 2011.

Tempo e narrativa. Tradução de Claudia Berliner. São Paulo: . La métaphore vive. Paris: Éditions du Seuil, 1975.

SCHMIDT, Lawrence K. Hermenêutica. Trad. Fábio Ribeiro. Petrópolis, RJ: Editora Vozes, 2014.

ŠKRABÁNEK, Petr. Night of a thousand tiers. New York: Syracuse University Press, 2007.

TAVARES, Hênio Último da Cunha. Teoria literária. Belo Horizonte: Editora Itatiaia, 2002.

TINDALL, William York. A reader's guide to Finnegans wake. New York: Thames and Hudson, 1964.

TREIP, Andrew. Finnegans wake: teems of times. Amsterdam: Atlanta, 1994.

UDAYA, Kumar. Joycean labyrinth: repetition, time and tradition in Ulysses. New York: Oxford University Press, 1991.

VICO, Giambattista. Ciência nova. Tradução de Sebastião José Roque. São Paulo: Ícone, 2008.

Princípios de (uma) ciência nova: acerca da natureza comum das nações. São Paulo: Abril Cultural, 1984. 